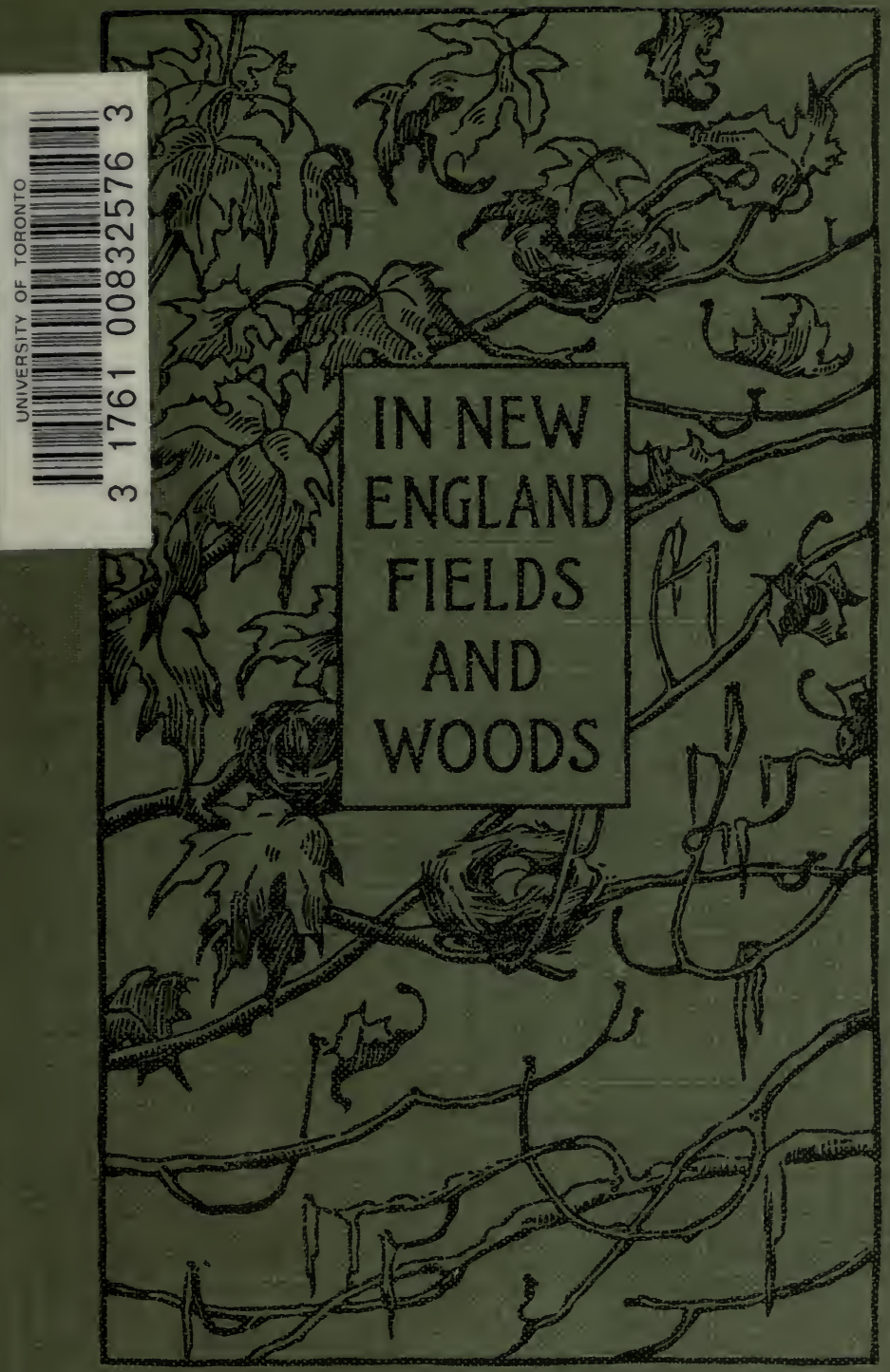






\section{3y Rowland $\mathbb{E}$. Rabinson}

OUT OF BONDAGE. $16 \mathrm{mo}, \$ \mathrm{r} .25$. IN NEW ENGLAND FIELDS AND WOODS. $16 \mathrm{mo}, \$ 1.25$.

DANVIS FOLKS. A Novel. 16mo. \$1.25.

UNCLE 'LISHA'S OUTING, $16 \mathrm{mo}, \$ 1.25$.

A DANVIS PIONEER, $16 \mathrm{mo}, \$ \mathrm{x} .25$.

SAM LOVEL'S BOY. I6mo, \$r.25.

VERMONT: A Study of Independence. In American Commonwealths Series. With Map. $16 \mathrm{mo}$, gilt top, $\$ 1.25$.

HOUGHTON, MIFFLIN \& COMPANY, Boston AND New York. 


\title{
In New England Fields and Woods
}

\author{
By \\ Rowland E. Robinson
}

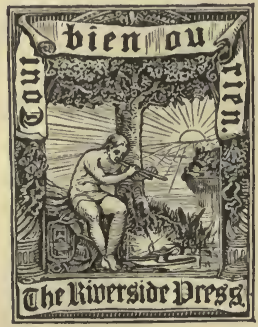

Boston and New York Houghton, Mifflin and Company (che laturgioe Bresid, Cambrioge 


\section{QH \\ 81 \\ R69}

Copyright, 1896 ,

By ROWLAND E. ROBINSON。

All rights reserved.

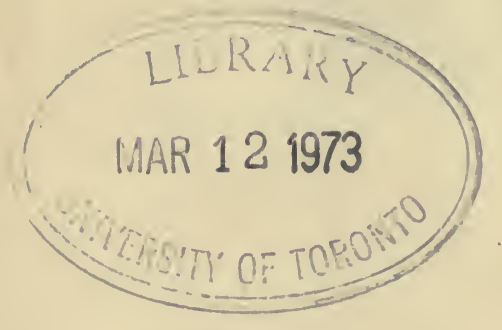


To

THE MEMORY OF

MY MOTHER

THIS BOOK

IS AFFECTIONATELY INSCRIBED

\& 
Digitized by the Internet Archive in 2008 with funding from Microsoft Corporation 
THE weather and the changes of the seasons are such common and convenient topics that one need not apologize for talking about them, though he says nothing new.

Still less need one make an apology if he becomes garrulous in relation to scenes which are now hidden from him by a curtain of darkness, or concerning some humble acquaintances with whom he was once on familiar terms, but who now and hereafter can only be memories, though they are yet near him and he may still hear their voices.

So without excuse I offer this collection of sketches, which with a few exceptions were first published in the columns of "Forest and Stream."

R. E. R. 



\section{CONTENTS}

I. The Nameless Season • • • I

II. MARCH DAYS • . . . • • 5

III. The HoMe FIRESIDE •. • . 13

IV. THE CROW . . . . . • • 17

V. The Mink • • • • . . . 22

VI. APRIL DAYS . . . • • . 27

VII. THE WOODCHUCK . • • • 33

VIII. The Chipmunk • • • • • 37

IX. Spring Shooting . . . . . 40

X. The Garter-SNake . • • • • 43

XI. The Toad . . . . . . 48

XII. MAY DAYS . . . . • . 52

XIII. The Bobolink . . . . . 56

XIV. The Golden - Winged Wood-

PECKER • • • • • • • • 59

XV. June DAys . . . . . . . 63

XVI. The Bullfrog . . . . . 66

XVII. The ANGleR . . . . . . 70

XVIII. Farmers and Field Sports • 79

XIX. To a Trespass Sign . . . 84

XX. A Gentle Sportsman . . . 88

XXI. July Days . • . • . • • • 9I

XXII. Camping OUT . • • . . . 98

XXIII. The CAMP-Fire . . . : . . 103

XXIV. A RAINY DAY IN CAMP . . IO7

XXV. August Days . . . . . . . II3

XXVI. A Voyage in THE DARK . . II8

XXVII. The Summer Camp-Fire . • 129

XXVIII. The Raccoon . . . . . . 132

XXIX. The Reluctant Camp-Fire . I4I 
XXX. September Days . . . . . . 143

XXXI. A Plea for the UNPRotected I 8

XXXII. The Skunk . . . . . . I 54

XXXIII. A CAMP-FIRE RUN WILD . . I58

XXXIV. The Dead Camp-Fire . . . I63

XXXV. OCTOBER DAYS . . . . . . 168

XXXVI. A CoMmon EXPERIENCE - . . 172

XXXVII. The Red Squirrel . . . . 178

XXXVIII. The Ruffed Grouse . . . I82

XXXIX. Two Shots . . . . . . 189

XL. November Days . . . . . 196

Xli. The Muskrat . . . . . 201

XLII. November Volces . . . . 205

XLIII. ThanKSGIVING . . . . . 208

XLIV. December Days . . . . . $21 \mathrm{I}$

XLV. Winter VoICES . . . . . 216

XlVi. The Varying Hare. . . . . 219

XlViI. The Winter Camp-Fire •. . 224

XlVIII. January Days . . . . . 229

XLIX. A New England Woodpile - 235

L. A Century of Extermination 25 I

LI. The Persistency of Pests . . 255

LII. The Weasel . . . . . . 260

LIII. February Days . . . . 263

LIV. The FoX . . . . . . . . 270

LV. AN ICE-STORM . . . . . . 276

LVI. Spare the Trees . . . . . 28 I

LVII. The ChickadeE . . . . 284 


\section{IN NEW ENGLAND FIELDS AND WOODS}

THE NAMELESS SEASON

IN the March page of our almanac, opposite the 20 th of the month we find the bold assertion, "Now spring begins;" but in the northern part of New England, for which this almanac was especially compiled, the weather does not bear out the statement.

The snow may be gone from the fields except in grimy drifts, in hollows and along fences and woodsides; but there is scarcely a sign of spring in the nakedness of pasture, meadow, and ploughed land, now more dreary in the dun desolation of lifeless grass, débris of stacks, and black furrows than when the first snow covered the lingering greenness of December. 
It is quite as likely that the open lands are still under the worn and dusty blanket of snow, smirched with all the litter cast upon it by cross-lot-faring teams, and wintry winds blowing for months from every quarter. The same untidiness pervades all outdoors. We could never believe that so many odds and ends could have been thrown out of doors helter-skelter, in three months of ordinary life, till the proof confronts us on the surface of the subsiding snow or lies stranded on the bare earth. The wind comes with an icier breath from the wintrier north, and yet blows untempered from the south, over fields by turns frozen and sodden, through which the swollen brooks rush in yellow torrents with sullen monotonous complaint.

One may get more comfort in the woods, though the snow still lies deep in their shelter ; for here may be found the sugarmaker's camp, with its mixed odors of pungent smoke and saccharine steam, its wide environment of dripping spouts and tinkling tin buckets, signs that at last the pulse of the trees is stirred by a subtle promise of returning spring. 
The coarse-grained snow is strewn thickly with shards of bark that the trees have sloughed in their long hibernation, with shreds and tatters of their tempesttorn branches. But all this litter does not offend the eye nor look out of place, like that which is scattered in fields and about homesteads. When this three months' downfall of fragments sinks to the carpet of flattened leaves, it will be at one with it, an inwoven pattern, as comely as the shifting mesh of browner shadows that trunks and branches weave between the splashes of sunshine. Among these is a garnishment of green moss patches and fronds of perennial ferns which tell of life that the stress of winter could not overcome. One may discover, amid the purple lobes of the squirrelcup leaves, downy buds that promise blossoms, and others, callower, but of like promise, under the rusty links of the arbutus chain.

One hears the resonant call of a woodpecker rattled out on a seasoned branch or hollow stub, and may catch the muffled. beat of the partridge's drum, silent since the dreamy days of Indian summer, now 
throbbing again in slow and accelerated pulsations of evasive sound through the unroofed arches of the woodlands. And one may hear, wondering where the poor vagrants find food and water, the wild clangor of the geese trumpeting their aerial northward march, and the quick whistle of the wild duck's pinions, - hear the carol of an untimely bluebird and the disconsolate yelp of a robin ; but yet it is not spring.

Presently comes a great downfall of snow, making the earth beautiful again with a whiteness outshining that of the winter that is past. The damp flakes cling to every surface, and clothe wall, fence and tree, field and forest, with a more radiant mantle than the dusty snow and slanted sunshine of winter gave them.

There is nothing hopeful of spring but a few meagre signs, and the tradition that spring has always come heretofore.

It is not winter, it is not spring, but a season with an individuality as marked as either, yet without a name. 


\section{II}

MARCH DAYS

BACK and forth across the land, in swift and sudden alternation, the March winds toss days of bitter cold and days of genial warmth, now out of the eternal winter of the north, now from the endless summer of the tropics.

Repeated thawing and freezing has given the snow a coarse grain. It is like a mass of fine hailstones and with no hint of the soft and feathery flakes that wavered down like white blossoms shed from the unseen bloom of some far-off upper world and that silently transformed the unseemliness of the black and tawny earth into the beauty of immaculate purity.

One day, when the wind breathes from the south a continuous breath of warmth, your feet sink into this later coarseness come of its base earthly association, with a grinding slump, as in loose wet sand, so 
deep, perhaps, that your tracks are gray puddles, marking your toilsome way.

As you wallow on, or perch for a moment's rest on a naked fence-top among the smirched drifts, you envy the crows faring so easily along their aerial paths above you. How pleasant are the voices of these returning exiles, not enemies now, but friendly messengers, bringing tidings of spring. You do not begrudge them the meagre feasts they find, the frozen apple still hanging, brown and wrinkled, in the bare orchard, or the winter-killed youngling of flock or herd, cast forth upon a dunghill, and which discovered, one generous vagabond calls all his black comrades to partake of.

Watching them as they lag across the sky, yet swifter than the white clouds drift above them, you presently note that these stand still, as you may verify by their blue shadows on the snow, lying motionless, with the palpitating shadows of the crows plunging into them on this side, then, lost for an instant in the blue obscurity, then, emerging on that side with the same untiring beat of shadowy wings. A puff of wind comes out of the 
north, followed by an angry gust, and then a howling wintry blast that the crows stagger against in labored flight as they make for the shelter of the woods.

You, too, toil to shelter and fireside warmth, and are thankful to be out of the biting wind and the treacherous footing. The change has come so suddenly that the moist, grainy snow is frozen before it has time to leach, and in a little while gives you a surface most delightful to walk upon, and shortens distances to half what they were. It has lost its first pure whiteness wherewith no other whiteness can compare, but it is yet beyond all things else, and in the sunlight dazzles you with a broad glare and innumerable scintillating points of light, as intense as the sun itself.

The sunshine, the bracing air, the swaying boughs of the pines and hemlocks beckoning at the woodside, and the firm smooth footing, irresistibly invite you forth. Your feet devour the way with crisp bites, and you think that nothing could be more pleasant to them till you are offered a few yards of turf, laid bare by winds and sun, and then you real- 
ize that nothing is quite so good as the old stand-by, a naked ground, and crave more of it, even as this is, and hunger for it with its later garnishing of grass and flowers. The crows, too, are drawn to these bare patches and are busy upon them, and you wonder what they can find ; spiders, perhaps, for these you may see in thawy days crawling sluggishly over the snow, where they must have come from the earth.

The woods are astir with more life than a month ago. The squirrels are busy and noisy, the chickadees throng about you, sometimes singing their sweet brief song of three notes; the nuthatches pipe their tiny trumpets in full orchestra, and the jays are clamoring their ordinary familiar cries with occasional notes that you do not often hear. One of these is a soft, rapidly uttered cluck, the bird all the time dancing with his body, but not with his feet, to his own music, which is pleasant to the ear, especially when you remember it is a jay's music, which in the main cannot be recommended. To-day, doubtless, he is practicing the allurements of the mating season. 
You hear the loud cackle of a logcock making the daily round of his preserves, but you are not likely to get more than a glimpse of his black plumage or a gleam of his blood-red crest.

By rare luck you may hear the little Acadian owl filing his invisible saw, but you are likelier to see him and mistake him for a clot of last year's leaves lodged midway in their fall to earth.

The forest floor, barred and netted with blue shadows of trunks and branches, is strewn with dry twigs, evergreen leaves, shards of bark, and shreds of tree-moss and lichen, with heaps of cone scales, the squirrel's kitchen middens, - the sign of a partridge's nightly roosting, similar traces of the hare's moonlight wanderings, and perhaps a fluff of his white fur, showing where his journeys have ended forever in a fox's maw.

Here and there the top of a cradle knoll crops out of the snow with its patches of green moss, sturdy upright stems and leaves and red berries of wintergreen, as fresh as when the first snow covered them, a rusty trail of mayflower leaves, and the flat-pressed purple lobes 
of squirrelcup with a downy heart of buds full of the promise of spring.

The woods are filled with a certain subtle scent quite distinct from the very apparent resinous and balsamic aroma of the evergreens, that eludes description, but as a kind of freshness that tickles the nose with longing for a more generous waft of it. You can trace it to no source, as you can the odors of the pine and the hemlocks or the sweet fragrance of the boiling sap, coming from the sugarmaker's camp with a pungent mixture of wood-smoke. You are also made aware that the skunk has been abroad, that reynard is somewhere to windward, and by an undescribed, generally unrecognized, pungency in the air that a gray squirrel lives in your neighborhood. Yet among all these more potent odors you still discover this subtle exhalation, perhaps of the earth filtered upward through the snow, perhaps the first awakening breath of all the deciduous trees.

Warmer shines the sun and warmer blows the wind from southern seas and southern lands. More and more the Io 
tawny earth comes in sight among puddles of melted snow, which bring the mirrored sky and its fleecy flocks of clouds, with treetops turned topsy-turvy, down into the bounds of fields. The brooks are alive again and babbling noisily over their pebbled beds, and the lake, hearing them, groans and cries for deliverance from its prison of ice.

On the marshes you may find the ice shrunken from the shores and an intervening strip of water where the muskrat may see the sun and the stars again. You hear the trumpets of the wild geese and see the gray battalion riding northward on the swift wind.

The sun and the south wind, which perhaps bears some faint breath of stolen fragrance from far-off violet banks, tempt forth the bees, but they find no flowers yet, not even a squirrelcup or willow catkin, and can only make the most of the fresh sawdust by the wood-pile and the sappy ends of maple logs.

Down from the sky, whose livery he wears and 'whose song he sings, comes the heavenly carol of the bluebird; the 
song sparrow trills his cheery melody; the first robin is announced to-day, and we cry, "Lo, spring has come." But tomorrow may come winter and longer waiting. 


\section{III}

\section{THE HOME FIRESIDE}

WeEKS ago the camp-fire shed its last glow in the deserted camp, its last thin thread of smoke was spun out and vanished in the silent air, and black brands and gray ashes were covered in the even whiteness of the snow. The unscared fox prowls above them in curious exploration of the desolate shanty, where wood-mice are domiciled and to whose sunny side the partridge comes to bask; the woodpecker taps unbidden to enter or departs from the always open door; and under the stars that glitter through the net of branches the owl perches on the snowy ridge and mopes in undisturbed solemnity.

For a time, camping-days are over for the sportsman, and continue only for the lumberman, the trapper, and the merciless crust-hunter, who makes his secret lair in the depths of the forest. 
In the chill days and evenings that fall first in the interim between winter and summer camping, the man who makes his outings for sport and pleasure must content himself by his own fireside, whose constant flame burns throughout the year.

Well may he be content when the un. tempered winds of March howl like a legion of wolves at his door, snow and sleet pelt roof and pane with a continuous volley from the lowering sky, or when the chilly silence of the last winter nights is broken by the sharp crack of frozen trees and timbers, as if a hidden band of riflemen were besieging the house. Well may he be content, then, with the snug corner of his own hearthstone, around which are gathered the good wife, the children, and his camp companions, the dogs.

Better than the camp, is this cosy comfort in days and nights such as these, or in those that fall within that unnamed season that lies between winter and spring, when, if one stirs abroad, his feet have sorry choice between saturated snow and oozy mould, - a dismal season 
but for its promise of brighter days, of free streams, green trees, and bird songs. Better, now, this genial glow that warms one's marrow than the camp-fire that smokes or roasts one's front while his back freezes. With what perfect contentment one mends his tackle and cleans his gun for coming days of sport, while the good wife reads racy records of camp-life from Maine to California, and he listens with attention half diverted by break or rust spot, or with amused watching of the youngsters playing at camping out. The callow campers assail him with demands for stories, and he goes over, for their and his own enjoyment, old experiences in camp and field, while the dogs dream by the fire of sport past or to come, - for none but dogs know whether dog's dreams run backward or forward.

Long-used rod and gun suggest many a tale of past adventure as they bring to mind recollections of days of sport such as may never come again. The great logs in the fireplace might tell, if their flaming tongues were given speech, of camps made long ago beneath their lusty 
branches, and of such noble game as we shall never see, - moose, elk, deer, panther, wolf, and bear, which are but spectres in the shadowy forest of the past. But the red tongues only roar and hiss as they lick the crackling sinews of oak and hickory, and tell nothing that ordinary ears may catch. Yet one is apt to fall dreaming of bygone days, and then of days that may come to be spent by pleasant summer waters and in the woods gorgeous with the ripeness of autumn.

So one is like to dream till he awakens and finds himself left with only the dogs for comrades, before the flameless embers, deserted even by the shadows that erstwhile played their grotesque pranks behind him. Cover the coals as if they were to kindle to-morrow's camp-fire, put the yawning dogs to bed, and then to bed and further dreaming. 


\section{IV}

THE CROW

THE robin's impatient yelp not yet attuned to happy song, the song sparrow's trill, the bluebird's serene melody, do not herald the coming of spring, but attend its vanguard. These blithe musicians accompany the soft air that bares the fields, empurples the buds, and fans the bloom of the first squirrelcups and sets the hyla's shrill chime a-ringing.

Preceding these, while the fields are yet an unbroken whiteness and the coping of the drifts maintain the fantastic grace of their storm-built shapes, before a recognized waft of spring is felt or the voice of a freed stream is heard, comes that sable pursuivant, the crow, fighting his way against the fierce north wind, tossed alow and aloft, buffeted to this side and that, yet staggering bravely onward, and sounding his trumpet in the face of his raging antagonist, and far in 
advance of its banners, proclaiming spring.

It is the first audible promise of the longed-for season, and it heartens us, though there be weary days of waiting for its fulfillment, while the bold herald is beset by storm and pinched with hunger as he holds his outpost and gleans his scant rations in the winter-desolated land.

He finds some friendliness in nature even now. Though her forces assail him with relentless fury, she gives him here the shelter of her evergreen tents, in windless depths of woodland; bares for him there a rood of sward or stubble whereon to find some crumb of comfort ; leaves for him ungathered apples on the naked boughs, and on the unpruned tangles of vines wild grapes, - poor raisins of the frost, - the remnants of autumnal feasts of the robins and partridges.

Thankful now for such meagre fare and eager for the fullness of disgusting repasts, in the bounty of other seasons, he becomes an epicure whom only the choicest food will satisfy. He has the 18 
pick of the fattest grubs; he makes stealthy levies on the earliest robins' nests; and from some lofty lookout or aerial scout watches the farmer plant the corn and awaits its sprouting into the dainty tidbits, a fondness for whose sweetness is his overmastering weakness. For this he braves the terrible scarecrow and the dread mystery of the cornfield's lined boundary, for this risks life and forfeits the good name that his better deeds might give him. If he would not be tempted from grubs and carrion, what a worthy bird he might be accounted. In what good if humble repute might he live, how lamented, die. O Appetite! thou base belly-denned demon, for what sins of birds and men art thou accountable!

In the springtide days, the crow turns aside from theft and robbery to the softer game of love, whereunto you hear the harsh voice attuned in cluttering notes. After the wooing the pair begin house building and keeping.

It is the rudest and clumsiest of all bird architecture that has become the centre of their cares - such a jumble of 
sticks and twigs as chance might pile on its forked foundations; but woe betide the hawk who ventures near, or owl who dares to sound his hollow trumpet in the sacred precincts. At the first alarm signal, as suddenly and mysteriously as Robin Hood's merry men appeared at the winding of his horn, the black clansmen rally from every quarter of the greenwood, to assail the intruder and force him to ignominious retreat.

When at last the young crows, having clad their uncouth nakedness with full sable raiment, are abroad in the world, they, with unwary foolhardiness and incessant querulous cries of hunger or alarm, are still a constant source of anxiety to parents and kindred. But in the late summer, when the youngsters have come to months of discretion and the elders are freed from the bondage of their care, a long holiday begins for all the tribe. The corn has long since ceased to tempt them, and the persecution of man has abated. The shorn meadows and the close-cropped pastures swarm with grasshoppers, and field and forest offer their abundant fruits. 
Careless and uncared for, what happy lives they lead, sauntering on sagging wing through the sunshine from chosen field to chosen wood, and at nightfall encamping in the fragrant tents of the pines.

At last the gay banners of autumn signal departure, and the gathered clans file away in straggling columns, flecking the blue sky with pulsating dots of blackness, the green earth with wavering shadows. Sadly we watch the retreat of the sable cohorts, whose desertion leaves our northern homes to the desolation of winter. 


\section{V}

THE MINK

This little fur-bearer, whose color has been painted darker than it is, singularly making his name proverbial for blackness, is an old acquaintance of the angler and the sportsman, but not so familiar to them and the country boy as it was twoscore years ago.

It was a woeful day for the tribe of the mink when it became the fashion for other folk to wear his coat, which he could only doff with the subtler garment of life.

Throughout the term of his exaltation to the favor of fashion, he was lain in wait for at his own door and on his thoroughfares and by-paths by the traps, dead-falls, and guns of professional and amateur trappers and hunters, till the fate of his greater cousin the otter seemed to overtake him. But the fickle empress who raised him to such perilous 
estate, changing her mood, thrust him down almost to his old ignoble but safer rank, just in time to avert the impending doom of extermination. Once more the places that knew him of old, know him again.

In the March snow you may trace the long span of his parallel footprints where, hot with the rekindled annual fire of love, he has sped on his errant wooing, turning not aside for the most tempting bait, halting not for rest, hungering only for a sweetheart, wearied with nothing but loneliness. Yet weary enough would you be if you attempted to follow the track of but one night's wandering along the winding brook, through the tangle of windfalls, and across the rugged ledges that part stream from stream. When you go fishing in the first days of summer, you may see the fruits of this early springtide wooing in the dusky brood taking their primer-lesson in the art that their primogenitors were adepts in before yours learned it. How proud one baby fisher is of his first captured minnow, how he gloats over it and defends 
his prize from his envious and less fortunate brothers.

When summer wanes, they will be a scattered family, each member shifting for himself. Some still haunt the alder thicket where they first saw light, whose netted shadows of bare branches have thickened about them to continued shade of leafage, in whose midday twilight the red flame of the cardinal flower burns as a beacon set to guide the dusky wanderer home. Others have adventured far down the winding brook to the river, and followed its slowing current, past rapids and cataract, to where it crawls through the green level of marshes beloved of water fowl and of gunners, whose wounded victims, escaping them, fall an easy prey to the lurking mink.

Here, too, in their season are the tender ducklings of wood duck, teal, and dusky duck, and, all the year round, fat muskrats, which furnish for the price of conquest a banquet that the mink most delights in.

In the wooded border are homes ready builded for him under the buttressed 
trunks of elms, or in the hollow boles of old water maples, and hidden pathways through fallen trees and under low green arches of ferns.

With such a home and such bountiful provision for his larder close at hand, what more could the heart and stomach of mink desire? Yet he may not be satisfied, but longs for the wider waters of the lake, whose translucent depths reveal to him all who swim beneath him, fry innumerable; perch displaying their scales of gold, shiners like silver arrows shot through the green water, the lesser bass peering out of rocky fastnesses, all attainable to this daring fisher, but not his great rivals, the bronze-mailed bass and the mottled pike, whose jaws are wide enough to engulf even him.

Here, while you rest on your idle oar or lounge with useless rod, you may see him gliding behind the tangled net of cedar roots, or venturing forth from a cranny of the rocks down to the brink, and launching himself so silently that you doubt whether it is not a flitting shadow till you see his noiseless wake 
breaking the reflections lengthening out behind him.

Of all swimmers that breathe the free air none can compare with him in swiftness and in a grace that is the smooth and even flow of the poetry of motion. Now he dives, or rather vanishes from the surface, nor reappears till his wake has almost flickered out.

His voyage accomplished, he at once sets forth on exploration of new shores or progress through his established domain, and vanishes from sight before his first wet footprints have dried on the warm rock where he landed.

You are glad to have seen him, thankful that he lives, and you hope that, sparing your chickens and your share of trout, partridges, and wild ducks, he too may be spared from the devices of the trapper to fill his appointed place in the world's wildness. 


\section{VI}

APRIL DAYS

AT last there is full and complete assurance of spring, in spite of the baldness of the woods, the barrenness of the fields, bleak with sodden furrows of last year's ploughing, or pallidly tawny with bleached grass, and untidy with the jetsam of winter storms and the wide strewn litter of farms in months of foddering and wood-hauling.

There is full assurance of spring in such incongruities as a phœbe a-perch on a brown mullein stalk in the midst of grimy snow banks, and therefrom swooping in airy loops of flight upon the flies that buzz across this begrimed remnant of winter's ermine, and of squirrelcups flaunting bloom and fragrance in the face of an ice cascade, which, with all its glitter gone, hangs in dull whiteness down the ledges, greening the moss with the moisture of its wasting sheet of pearl. 
The woodchuck and chipmunk have got on top of the world again. You hear the half querulous, half chuckling whistle of the one, the full-mouthed persistent cluck of the other, voicing recognition of the season.

The song of the brooks has abated something of its first triumphant swell, and is often overborne now by the jubilant chorus of the birds, the jangled, liquid gurgle and raucous grating of the blackbirds, the robin's joyous song with its frequent breaks, as if the thronging notes outran utterance, the too brief sweetness of the meadowlark's whistle, the bluebird's carol, the cheery call of the phœbe, the trill of the song sparrow, and above them all the triumph of the hawk in its regained possessions of northern sky and earth.

The woods throb with the muffled beat of the partridge's drum and the sharp tattoo of the woodpecker, and are filled again with the sounds of insect life, the spasmodic hum of flies, the droning monotone of bees busy among the catkins and squirrelcups, and you may see a butterfly, wavering among the 
gray trees, soon to come to the end of his life, brief at its longest, drowned in the seductive sweets of a sap bucket.

The squirrels are chattering over the wine of the maple branches they have broached, in merrier mood than the hare, who limps over the matted leaves in the raggedness of shifting raiment, fitting himself to a new inconspicuousness.

We shall not find it unpleasant nor unprofitable to take to the woods now, for we may be sure that they are pleasanter than the untidy fields. Where nature has her own way with herself, she makes her garb seemly even now, after all the tousling and rents she gave it in her angry winter moods. The scraps of moss, bark, and twigs with which the last surface of the snow was obtrusively littered lie now unnoticed on the flatpressed leaves, an umber carpet dotted here with flecks of moss, there sprigged with fronds of evergreen fern, purple leaves of squirrelcups, with their downy buds and first blossoms. Between banks so clad the brook babbles as joyously as amid all the bloom and leafage of June, 
and catches a brighter gleam from the unobstructed sunbeams. So befittingly are the trees arrayed in graceful tracery of spray and beads of purpling buds, that their seemly nakedness is as beautiful as attire of summer's greenness or autumn's gorgeousness could make them.

Never sweeter than now, after the long silence of winter, do the birds' songs sound, and never in all the round of the year is there a better time to see them than when the gray haze of the branches is the only hiding for their gay wedding garments.

If you would try your skill at stillhunting, follow up that muffled roll that throbs through the woods, and if you discover the ruffed grouse strutting upon his favorite log, and undiscovered by him can watch his proud performance, you will have done something better worth boasting of than bringing him to earth from his hurtling flight.

Out of the distant fields come, sweet and faint, the call of the meadowlark and the gurgle of the blackbirds that throng the brookside elms. From high 
overhead come down the clarion note of the goose, the sibilant beat of the wild ducks' wings, the bleat of the snipe and the plover's cry, each making his way to northern breeding grounds. Are you not glad they are going as safely as their uncaught shadows that sweep swiftly across the shadowy meshes of the forest floor? Are you not content to see what you see, hear what you hear, and kill nothing but time?

Verily, you shall have a clearer conscience than if you were disturbing the voice of nature with the discordant uproar of your gun, and marring the fresh odors of spring with the fumes of villainous saltpetre.

In the open marshes the lodges of the muskrats have gone adrift in the floods; but the unhoused inmates count this a light misfortune, since they may voyage again with heads above water, and go mate-seeking and food-gathering in sunshine and starlight, undimmed by roof of ice. As you see them cutting the smooth surface with long, swift, arrowy wakes, coasting the low shore in quest of brown sweethearts and wives, whimper- 
ing their plaintive call, you can hardly imagine the clumsy body between that grim head and rudder-like tail capable of such graceful motion.

The painted wood drake swims above the submerged tree roots; a pair of dusky ducks splash to flight, with a raucous clamor, out of a sedgy cove at your approach; the thronging blackbirds shower liquid melody and hail of discord from the purple-budded maples above you. All around, from the drift of floating and stranded water weeds, arises the dry, crackling croak of frogs, and from sunny pools the vibrant trill of toads.

From afar come the watery boom of a bittern, the song of a trapper and the hollow clang of his setting pole dropping athwart the gunwales of his craft, the distant roar of a gun and the echoes rebounding from shore to shore.

The grateful odor of the warming earth comes to your nostrils; to your ears, from every side, the sounds of spring ; and yet you listen for fuller confirmation of its presence in the long-drawn wail of the plover and the rollicking melody of the bobolink. 


\section{VII}

\section{THE WOODCHUCK}

Chancing to pass a besmirched April snowbank on the border of a hollow, you see it marked with the footprints of an old acquaintance of whom for months you have not seen even so much as this.

It is not that he made an autumnal pilgrimage, slowly following the swift birds and the retreating sun, that you had no knowledge of him, but because of his home-keeping, closer than a hermit's seclusion. These few cautious steps, venturing but half way from his door to the tawny naked grass that is daily edging nearer to his threshold, are the first he has taken abroad since the last bright lingering leaf fluttered down in the Indian summer haze, or perhaps since the leaves put on their first autumnal tints.

He had seen all the best of the year, the blooming of the first flowers, the springing of the grass and its growth, 
the gathering of the harvests and the ripening of fruits, and possibly the gorgeousness of autumn melting into sombre gray. He had heard all the glad songs of all the birds and the sad notes of farewell of bobolink and plover to their summer home; he had seen the swallows depart and had heard the droning of the bumblebee among the earliest and latest of his own clover blossoms. All the best the world had to give in the round of her seasons, luxuriant growth to feed upon, warm sunshine to bask in, he had enjoyed; of her worst, he would have none. So he bade farewell to the gathering desolation of the tawny fields and crept closer to the earth's warm heart to sleep through the long night of winter, till the morning of spring. The wild scurry of wind-tossed leaves swept above him un. heard, and the pitiless beat of autumnal rain and the raging of winter storms that heaped the drifts deeper and deeper over his forsaken door. The bitterness of cold, that made the furred fox and the muffled owl shiver, never touched him in his warm nest. So he shirked the hardships of winter without the toil of a 
journey in pursuit of summer, while the starved fox prowled in the desolate woods and barren fields, the owl hunted beneath the cold stars, and the squirrel delved in the snow for his meagre fare.

By and by the ethereal but potent spirit of spring stole in where the frost-elves could not enter, and awakening the earth awakened him. Not by a slow and often impeded invasion of the senses, but as by the sudden opening of a door, he sees the naked earth again warming herself in the sun, and hears running water and singing birds. No wonder that with such surprise the querulous tremolo of his whistle is sharply mingled with these softer voices.

Day by day as he sees the sun-loved banks blushing greener, he ventures further forth to visit neighbors or watch his clover, or dig a new home in a more favored bank, or fortify himself in some rocky stronghold where boys and dogs may not enter. Now, the family may be seen moving, with no burden of furniture or provision, but only the mother with her gray cubs, carried as a cat carries her kittens, one by one to the new home among the fresher clover. 
On the mound of newly digged earth before it, is that erect, motionless, gray and russet form a half decayed stump uprising where no tree has grown within your memory? You move a little nearer to inspect the strange anomaly, and lo! it vanishes, and you know it was your old acquaintance, the woodchuck, standing guard at his door and overlooking his green and blossoming domain.

Are you not sorry, to-day at least, to hear the boys and the dog besieging him in his burrow or in the old stone wall wherein he has taken sanctuary? Surely, the first beautiful days of his open-air life should not be made so miserable that he would wish himself asleep again in the safety and darkness of winter. But you remember that you were once a boy, and your sympathies are divided between the young savages and their intended prey, which after all is likelier than not to escape.

He will tangle the meadow-grass and make free with the bean patch if he chances upon it, yet you are glad to see the woodchuck, rejoicing like yourself in the advent of spring. 


\section{VIII}

THE CHIPMUNK

As the woodchuck sleeps away the bitterness of cold, so in his narrower chamber sleeps the chipmunk. Happy little hermit, lover of the sun, mate of the song sparrow and the butterflies, what a goodly and hopeful token of the earth's renewed life is he, verifying the promises of his own chalices, the squirrelcups, set in the warmest corners of the woodside, with libations of dew and shower drops, of the bluebird's carol, the sparrow's song of spring.

Now he comes forth from his long night into the fullness of sunlit day, to proclaim his awakening to his summer comrades, a gay recluse clad all in the motley, a jester, maybe, yet no fool.

His voice, for all its monotony, is inspiring of gladness and contentment, whether he utters his thin, sharp chip or full-mouthed cluck, or laughs a chittering 
mockery as he scurries in at his narrow door.

He winds along his crooked pathway of the fence rails and forages for halfforgotten nuts in the familiar grounds, brown with strewn leaves or dun with dead grass. Sometimes he ventures to the top rail and climbs to a giddy tenfoot height on a tree, whence he looks abroad, wondering, on the wide expanse of an acre.

Music hath charms for him, and you may entrance him with a softly whistled tune and entice him to frolic with a herds-grass head gently moved before him.

When the fairies have made the white curd of mallow blossoms into cheeses for the children and the chipmunk, it is a pretty sight to see him gathering his share handily and toothily stripping off the green covers, filling his cheek pouches with the dainty disks and scampering away to his cellar with his ungrudged portion. Alack the day, when the sweets of the sprouting corn tempt him to turn rogue, for then he becomes a banned outlaw, and the sudden thun. 
der of the gun announces his tragic fate. He keeps well the secret of constructing his cunning house, without a show of heaped or scattered soil at its entrance. Bearing himself honestly, and escaping his enemies, the cat, the hawk, and the boy, he lives a long day of happy inoffensive life. Then when the filmy curtain of the Indian summer falls upon the year again, he bids us a long good-night. 


\section{IX}

SPRING SHOOTING

The Ram makes way for the Bull; March goes out and April comes in with sunshine and showers, smiles and tears. The sportsman has his gun in hand again with deadly purpose, as the angler his rod and tackle with another intention than mere overhauling and putting to rights. The smiles of April are for them.

The geese come wedging their way northward; the ducks awaken the silent marshes with the whistle of their pinions; the snipe come in pairs and wisps. to the thawing bogs - all on their way to breeding grounds and summer homes. The tears of April are for them. Wher ever they stop for a day's or an hour's rest, and a little food to strengthen and hearten them for their long journey, the deadly, frightful gun awaits to kill, maim, or terrify, more merciless than all the 40 
ills that nature inflicts in her unkindest moods.

Year after year men go on making laws and crying for more, to protect these fowl in summer, but in spring, when as much as ever they need protection, the hand of man is ruthlessly against them.

When you made that splendid shot last night in the latest gloaming that would show you the sight of your gun, and cut down that ancient goose, tougher than the leather of your gun-case, and almost as edible, of how many well-grown young geese of next November did you cheat yourself, or some one else of the brotherhood?

When from the puddle, where they were bathing their tired wings, sipping the nectar of muddy water, and nibbling the budding leaves of water weeds, you started that pair of ducks yesterday, and were so proud of tumbling them down right and left, you killed many more than you saw then; many that you might have seen next fall.

When the sun was shining down so warm upon the steaming earth that the 
robins and bluebirds sang May songs, those were very good shots you made, killing ten snipe straight and clean, and - they were very bad shots. For in November the ten might have been four times ten fat and lusty, lazy fellows, boring the oozy margins of these same pools where the frogs are croaking and the toads are singing to-day.

"Well, it's a long time to wait from November till the earth ripens and browns to autumn again. Life is short and shooting days are few at most. Let us shoot our goose while we may, though she would lay a golden egg by and by."

Farmers do not kill their breeding ewes in March, nor butcher cows that are to calve in a month; it does not pay. Why should sportsmen be less provident of the stock they prize so dearly; stock that has so few care-takers, so many enemies? Certainly, it does not pay in the long run. 
THE GAR'IER-SNAKE

WHEN the returned crows have become such familiar objects in the forlorn unclad landscape of early spring that they have worn out their first welcome, and the earliest songbirds have come to stay in spite of inhospitable weather that seems for days to set the calendar back a month, the woods invite you more than the fields. There nature is least under man's restraint and gives the first signs of her reawakening. In windless nooks the sun shines warmest between the meshes of the slowly drifting net of shadows.

There are patches of moss on gray rocks and tree trunks. Fairy islands of it, that will not be greener when they are wet with summer showers, arise among the brown expanse of dead leaves. The gray mist of branches and undergrowth is enlivened with a tinge of purple. Here 
and there the tawny mat beneath is uplifted by the struggling plant life below it or pierced through by an underthrust of a sprouting seed. There is a promise of bloom in blushing arbutus buds, a promise even now fulfilled by the first squirrelcups just out of their furry bracts and already calling the bees abroad. Flies are buzzing to and fro in busy idleness, and a cricket stirs the leaves with a sudden spasm of movement. The first of the seventeen butterflies that shall give boys the freedom of bare feet goes wavering past like a drifting blossom.

A cradle knoll invites you to a seat on the soft, warm cushion of dead leaves and living moss and purple sprigs of wintergreen with their blobs of scarlet berries, which have grown redder and plumper under every snow of the winter. This smoothly rounded mound and the hollow scooped beside it, brimful now of amber, sun-warmed water, mark the ancient place of a great tree that was dead and buried, and all traces by which its kind could be identified were mouldered away and obliterated, before you were born. 
The incessant crackling purr of the wood-frogs is interrupted at your approach, and they disappear till the wrinkled surface of the oblong pool grows smooth again and you perceive them sprawled along the bottom on the leaf paving of their own color. As you cast a casual glance on your prospective seat, carelessly noting the mingling of many hues, the brightness of the berries seems most conspicuous, till a moving curved and recurved gleam of gold on black and a flickering flash of red catch your eye and startle you with an involuntary revulsion.

With charmed eyes held by this new object, you grope blindly for a stick or stone. But, if you find either, forbear to strike. Do not blot out one token of spring's awakening nor destroy one life that rejoices in it, even though it be so humble a life as that of a poor gartersnake. He is so harmless to man, that, were it not for the old, unreasoning antipathy, our hands would not be raised against him ; and, if he were not a snake, we should call him beautiful in his stripes of black and gold, and in graceful motion 
- a motion that charms us in the undulation of waves, in their flickering reflections of sunlight on rushy margins and wooded shores, in the winding of a brook through a meadow, in the flutter of a pennant and the flaunting of a banner, the ripple of wind-swept meadow and grain field, and the sway of leafy boughs. His colors are fresh and bright as ever you will see them, though he has but today awakened from a long sleep in continual darkness.

$\mathrm{He}$ is simply enjoying the free air and warm sunshine without a thought of food for all his months of fasting. Perhaps he has forgotten that miserable necessity of existence. When at last he remembers that he has an appetite, you can scarcely imagine that he can have any pleasure in satisfying it with one huge mouthful of twice or thrice the ordinary diameter of his gullet. If you chance to witness his slow and painful gorging of a frog, you hear a cry of distress that might be uttered with equal cause by victim or devourer. When he has fully entered upon the business of reawakened life, many a young field46 
mouse and noxious insect will go into his maw to his own and your benefit. If there go also some eggs and callow young of ground-nesting birds, why should you question his right, you, who defer slaughter out of pure selfishness, that a little later you may make havoc among the broods of woodcock and grouse?

Of all living things, only man disturbs the nicely adjusted balance of nature. The more civilized he becomes the more mischievous he is. The better he calls himself, the worse he is. For uncounted centuries the bison and the Indian shared a continent, but in two hundred years or so the white man has destroyed the one and spoiled the other.

Surely there is little harm in this lowly bearer of a name honored in knighthood, and the motto of the noble order might be the legend written on his gilded mail, "Evil to him who evil thinks." If this sunny patch of earth is not wide enough for you to share with him, leave it to him and choose another for yourself. The world is wide enough for both to enjoy this season of its promise. 
DURING our summer acquaintance with her, when we see her oftenest, a valued inhabitant of our garden and a welcome twilight visitor at our threshold, we associate silence with the toad, almost as intimately as with the proverbially silent clam. In the drouthy or too moist summer days and evenings, she never awakens our hopes or fears with shrill prophecies of rain as does her nimbler and more aspiring cousin, the tree-toad.

A rustle of the cucumber leaves that embower her cool retreat, the spat and shuffle of her short, awkward leaps, are the only sounds that then betoken her presence, and we listen in vain for even a smack of pleasure or audible expression of self-approval, when, after a nervous, gratulatory wriggle of her hinder toes, she dips forward and, with a lightning-like out-flashing of her unerring 48 
tongue, she flicks into her jaws a fly or bug. She only winks contentedly to express complete satisfaction at her performance and its result.

Though summer's torrid heat cannot warm her to any voice, springtime and love make her tuneful, and every one hears the softly trilled, monotonous song jarring the mild air, but few know who is the singer. The drumming grouse is not shyer of exhibiting his performance.

From a sun-warmed pool not fifty yards away a full chorus of the rapidly vibrant voices arises, and you imagine that the performers are so absorbed with their music that you may easily draw near and observe them. But when you come to the edge of the pool you see only a half-dozen concentric circles of wavelets, widening from central points, where as many musicians have modestly withdrawn beneath the transparent curtain.

Wait, silent and motionless, and they will reappear. A brown head is thrust above the surface, and presently your last summer's familiar of the garden 
and doorstep crawls slowly out upon a barren islet of cobble-stone, and, assured that no intruder is within the precincts sacred to the wooing of the toads, she inflates her throat and tunes up her long, monotonous chant. Ere it ceases, another and another take it up, and from distant pools you hear it answered, till all the air is softly shaken as if with the clear chiming of a hundred swiftstruck, tiny bells. They ring in the returning birds, robin, sparrow, finch and meadow lark, and the first flowers, squirrelcup, arbutus, bloodroot, adder-tongue and moose-flower.

When the bobolink has come to his northern domain again and the oriole flashes through the budding elms and the first columbine droops over the gray ledges, you may still hear an occasional ringing of the toads, but a little later the dignified and matronly female, having lost her voice altogether, has returned to her summer home, while her little mate has exchanged his trill for a disagreeable and uncanny squawk, perhaps a challenge to his rivals, who linger 
about the scenes of their courtship and make night hideous until midsummer. Then a long silence falls on the race of toads - a silence which even hibernation scarcely deepens. 


\section{XII}

\section{MAY DAYS}

The lifeless dun of the close-cropped southward slopes and the tawny tangles of the swales are kindling to living green with the blaze of the sun and the moist tinder of the brook's overflow.

The faithful swallows have returned, though the faithless season delays. The flicker flashes his golden shafts in the sunlight and gladdens the ear with his merry cackle. The upland plover wails his greeting to the tussocked pastures, where day and night rings the shrill chorus of the hylas and the trill of the toads continually trembles in the soft air.

The first comers of the birds are already mated and nest-building, robin and song sparrow each in his chosen place setting the foundations of his house with mud or threads of dry grass. The crow clutters out his softest love note. The 
flicker is mining a fortress in the heart of an old apple-tree.

The squirrels wind a swift ruddy chain about a boll in their love chase, and even now you may surprise the vixen fox watching the first gambols of her tawny cubs by the sunny border of the woods.

The gray haze of undergrowth and lofty ramage is turning to a misty green, and the shadows of opening buds knot the meshed shadows of twigs on the brown forest floor, which is splashed with white moose-flowers and buds of bloodroot, like ivory-tipped arrows, each in a green quiver, and yellow adder-tongues bending above their mottled beds, and rusty trails of arbutus leaves leading to the secret of their hidden bloom, which their fragrance half betrays.

Marsh marigolds lengthen their golden chain, link by link, along the ditches. The maples are yellow with paler bloom, and the graceful birches are bent with their light burden of tassels. The dandelion answers the sun, the violet the sky. Blossom and greenness are everywhere; even the brown paths of the plough 
and harrow are greening with springing grain.

We listen to the cuckoo's monotonous flute among the white drifts of orchard bloom and the incessant murmur of bees, the oriole's half plaintive carol as of departed joys in the elms, and the jubilant song of the bobolink in the meadows, where he is not an outlaw but a welcome guest, mingling his glad notes with the merry voices of flower-gathering children, as by and by he will with the ringing cadence of the scythe and the vibrant chirr of the mower. Down by the flooded marshes the scarlet of the water maples and the flash of the starling's wing are repeated in the broad mirror of the still water. The turtle basks on the long incline of stranded logs.

Tally-sticks cast adrift are a symbol that the trapper's warfare against the muskrats is ended and that the decimated remnant of the tribe is left in peace to reëstablish itself. The spendthrift waste of untimely shooting is stayed. Wild duck, plover, and snipe have entered upon the enjoyment of a summer truce that will be unbroken, if the collector is 
not abroad at whose hands science ruthlessly demands mating birds and callow brood.

Of all sportsmen only the angler, often attended by his winged brother the kingfisher, is astir, wandering by pleasant waters where the bass lurks in the tangles of an eddy's writhing currents, or the perch poises and then-glides through the intangible golden meshes that waves and sunlight knit, or where the trout lies poised beneath the silver domes of foam bells.

The loon laughs again on the lake. Again the freed waves toss the shadows of the shores and the white reflections of white sails, and flash back the sunlight or the glitter of stars and the beacon's rekindled gleam.

Sun and sky, forest, field, and water, bird and blossom, declare the fullness of spring and the coming of summer.

55 


\section{XIII}

THE BOBOL.INK

THE woods have changed from the purple of swelling buds to the tender grayish green of opening leaves, and the sward is green again with new grass, when this pied troubadour, more faithful to the calendar than leaf or flower, comes back from his southern home to New England meadows to charm others than his dusky ladylove with his merry song. He seldom disappoints us by more than a day in the date of his arrival, and never fails to receive a kindly welcome, though the fickle weather may be unkind.

"The bobolinks have come" is as joyful a proclamation as announces the return of the bluebird and robin. Here no shotted salute of gun awaits him, and he is aware that he is in a friendly country. Though he does not court familiarity, he tolerates approach; and permits you to come within a dozen yards of the fence 
stake he has alighted on, and when you come nearer he goes but to the next, singing the prelude or finale of his song as he flies. Fewer yards above your head he poises on wing to sing it from beginning to end, you know not whether with intent to taunt you or to charm you, but he only accomplishes the latter. $\mathrm{He}$ seems to know that he does not harm us and that he brings nothing that we should not lose by killing him. Yet how cunningly he and his mate hide their nest in the even expanse of grass. That is a treasure he will not trust us with the secret of, and, though there may be a dozen in the meadow, we rarely find one.

Our New England fathers had as kindly a feeling for this blithe comer to their stumpy meadows, though they gave him the uncouth and malodorous name of skunk blackbird. He sang as sweetly to them as he does to us, and he too was a discoverer and a pioneer, finding and occupying meadows full of sunshine where had only been the continual shade of the forest, where no bobolink had ever been before. Now he has miles of 
grassy sunlit fields wherein he sings violet and buttercup, daisy and clover into bloom and strawberries into ripeness, and his glad song mingles with the happy voices of the children who come to gather them, and also chimes with the rarer music of the whetted scythe.

Then, long before the summer is past, he assumes the sober dress of his mate and her monosyllabic note, and fades so gradually out of our sight and hearing that he departs without our being aware of it. Summer still burns with unabated fervor, when we suddenly realize that there are no bobolinks. Nor are there any under the less changeful skies whither our changed bird has flown to be a reed-bird or rice-bird and to find mankind his enemies. $\mathrm{He}$ is no longer a singer but a gourmand and valued only as a choice morsel, doubtless delicious, yet one that should choke a. New Englander. 


\section{XIV}

THE GOLDEN-WINGED WOODPECKER

THE migrant woodpecker whose cheery cackle assures us of the certainty of spring is rich in names that well befit him. If you take to high-sounding titles for your humble friends, you will accept Colaptes auratus, as he flies above you, borrowing more gold of the sunbeams that shine through his yellow pinions, or will be content to call him simply golden-winged. When he flashes his wings in straight-away flight before you, or sounds his sharp, single note of alarm, or peers down from the door of his lofty tower, or hangs on its wooden wall, or clinging to a fence stake displays his mottled back, you recognize the fitness of each name the country folk have given him - flicker, yellow-hammer, yarrup, highhole or highholder, and what Thoreau often termed him, partridgewoodpecker. It is a wonder that the 
joyous cackle wherewith he announces his return from his winter sojourn in the South has not gained him another, and that love note, so like the slow whetting of a knife upon a steel, still another. Perhaps it is because they are especially sounds of spring and seldom if ever heard after the season of joyful arrival and love-making.

During the same season you frequently hear him attuning his harsh sharp voice to its softest note of endearment, a longdrawn and modulated variation of his cackle. When household cares begin, the lord and lady of the wooden tower, like too many greater and wiser twolegged folk, give over singing and soft words. At home and abroad their deportment is sober and business-like, and except for an occasional alarm-cry they are mostly silent.

As you wander through the orchard of an early midsummer day and pause beside an old apple-tree to listen to the cuckoo's flute or admire the airy fabric of the wood pewee's nest, a larger scale of lichen on the lichened boughs, you hear a smothered vibrant murmur close 60 
beside you, as if the heart of the old tree was pulsating with audible life. It is startlingly suggestive of disturbed yellow-jackets, but when you move around the trunk in cautious reconnoissance, you discover the round portal of a flicker's home, and the sound resolves itself into harmlessness. It is only the callow young clamoring for food, or complaining of their circumscribed quarters.

Not many days hence they will be out in the wide world of air and sunshine of which they now know as little as when they chipped the shell. Lusty fellows they will be then, with much of their parents' beauty already displayed in their bright new plumage and capable of an outcry that will hold a bird-eating cat at bay. A little later they will be, as their parents are, helpful allies against the borers, the insidious enemies of our apple-tree. It is a warfare which the groundling habits of the golden-wings make them more ready to engage in than any other of the woodpecker clans.

In sultry August weather, when the shrill cry of the cicada pierces the hot air like a hotter needle of sound, and the 
dry husky beat of his wings emphasizes the apparent fact of drouth as you walk on the desiccated slippery herbage of meadow and pasture, the golden-wings with all their grown-up family fly up before you from their feast on the ant hills and go flashing and flickering away like rockets shot aslant, into the green tent of the wild cherry trees to their dessert of juicy black fruit.

Early in the dreariness of November, they have vanished with all the horde of summer residents who have made the season of leaf, flower, and fruit the brighter by their presence. The desolate leafless months go by, till at last comes the promise of spring, and you are aware of a half unconscious listening for the golden-wings. Presently the loud, long, joyous iteration breaks upon your ear, and you hail the fulfillment of the promise and the blithe new comer, a golden link in the lengthening chain that is encircling the earth. 


\section{XV}

JUNE DAYS

JunE brings skies of purest blue, flecked with drifts of silver, fields and woods in the flush of fresh verdure, with the streams winding among them in crystal loops that invite the angler with promise of more than fish, something that tackle cannot lure nor creel hold.

The air is full of the perfume of locust and grape bloom, the spicy odor of pine and fir, and of pleasant voices - the subdued murmur of the brook's changing babble, the hum of bees, the stir of the breeze, the songs of birds. Out of the shady aisles of the woods come the flute note of the hermit thrush, the silvery chime of the tawny thrush; and from the forest border, where the lithe birches swing their shadows to and fro along the bounds of wood and field, comes that voice of June, the cuckoo's gurgling note of preparation, and then 
the soft, monotonous call that centuries ago gave him a name.

General Kukushna the exiles in Siberia entitle him; and when they hear his voice, every one who can break bounds is irresistibly drawn to follow him, and live for a brief season a free life in the greenwood. As to many weary souls and hampered bodies there, so to many such here comes the voice of the little commander, now persuasive, now imperative, not to men and women in exile or wearing the convict's garb, but suffering some sort of servitude laid upon them or self-imposed. Toiling for bread, for wealth, for fame, they are alike in bondage - chained to the shop, the farm, the desk, the office.

Some who hear, obey, and revel in the brief but delightful freedom of June days spent in the perfumed breath of full-leafed woods, by cold water-brooks and rippled lakes. Others listen with hungry hearts to the summons, but cannot loose their fetters, and can only answer with a sigh, "It is not for me," or "Not yet," and toil on, still hoping for future days of freedom. 
But saddest of all is the case of such as hear not, or, hearing, heed not the voice of the Kukushna, the voices of the birds, the murmurous droning of bees amid the blossoms, the sweet prattle of running waters and dancing waves. Though these come to them from all about, and all about them are unfolded the manifold beauties of this joyous month, no sign is made to them. Their dull ears hear not the voices of nature, neither do their dim eyes see the wondrous miracle of spring which has been wrought all about them. Like the man with the muck-rake, they toil on, intent only upon the filth and litter at their feet. Sad indeed must it be to have a soul so poor that it responds to no caress of nature, sadder than any imposition of servitude or exile which yet hinders not one's soul from arising with intense longing for the wild world of woods and waters when Kukushna sounds his soft trumpet call. 


\section{XVI}

THE BULLFROG

THE flooded expanse of the marshes has shrunken perceptibly along its shoreward boundaries, leaving a mat of dead weeds, bits of driftwood, and a waterworn selvage of bare earth to mark its widest limits. The green tips of the rushes are thrust above the amber shallows, whereon flotillas of water-shield lie anchored in the sun, while steel-blue devil's-needles sew the warm air with intangible threads of zigzag flight.

The meshed shadows of the watermaples are full of the reflections of the green and silver of young leaves. The naked tangle of button-bushes has become a green island, populous with garrulous colonies of redwings. The great flocks of wild ducks that came to the reopened waters have had their holiday rest, and journeyed onward to summer homes and cares in the further north. 
The few that remain are in scattered pairs and already in the silence and seclusion of nesting. You rarely see the voyaging muskrat or hear his plaintive love calls.

Your ear has long been accustomed to the watery clangor of the bittern, when a new yet familiar sound strikes it, the thin, vibrant bass of the first bullfrog's note. It may be lacking in musical quality, but it is attuned to its surroundings, and you are glad that the green-coated player has at last recovered his long-submerged banjo, and is twanging its water-soaked strings in prelude to the summer concert. $\mathrm{He}$ is a little out of practice, and his instrument is slightly out of tune, but a few days' use will restore both touch and resonance, when he and his hundred brethren shall awaken the marsh-haunting echoes and the sleeping birds with a grand twilight recital. It will reach your ears a mile away, and draw you back to the happy days of boyhood, when you listened for the bullfrogs to tell that fish would bite, and it was time for boys to go a-fishing.

In the first days of his return to the 67 
upper world of water, this old acquaintance may be shy, and neither permit nor offer any familiarity. The fixed placidity of his countenance is not disturbed by your approach, but if you overstep by one pace what he considers the proper limit, down goes his head under cover of the flood. Marking his jerky course with an underwake and a shiver of the rushes, he reappears, to calmly observe you from a safer distance.

Custom outwears his diffidence, and the fervid sun warms him to more genial moods, when he will suffer you to come quietly quite close to him and tickle his sides with a bullrush, till in an ecstasy of pleasure he loses all caution, and bears with supreme contentment the titillation of your finger tips. His flabby sides swell with fullness of enjoyment, his blinking eyes grow dreamy and the corners of his blandly expressionless mouth almost curve upward with an elusive smile. Not till your fingers gently close upon him does he become aware of the indiscretion into which he has lapsed, and with a frantic struggle he tears himself away from your grasp 
and goes plunging headlong into his nether element, bellowing out his shame and astonishment.

Another day as you troll along the channel an oar's length from the weedy borders, you see him afloat on his lilypad raft, heeding you no more than does the golden-hearted blossom whose orange odor drifts about him, nor is he disturbed by splash of oar nor dip of paddle, nor even when his bark and her perfume-freighted consort are tossed on your undulating wake.

As summer wanes you see and hear him less frequently, but he is still your comrade of the marshes, occasionally announcing his presence with a resonant twang and a jerky splash among the sedges.

The pickerel weeds have struck their blue banners to the conquering frost, and the marshes are sere, and silent, and desolate. When they are warmed again with the new life of spring, we shall listen for the jubilant chorus of our old acquaintance, the bullfrog. 


\section{XVII}

THE ANGLER

I

ANGLING is set down by the master of the craft, whom all revere but none now follow, as the Contemplative Man's Recreation; but is the angler, while angling, a contemplative man?

That beloved and worthy brother whose worm-baited hook dangles in quiet waters, placid as his mind - till some wayfaring perch, or bream, or bullhead shall by chance come upon it, he, meanwhile, with rod set in the bank, taking his ease upon the fresh June sward, not touching his tackle nor regarding it but with the corner of an eye - he may contemplate and dream day dreams. He may watch the clouds drifting across the blue, the green branches waving between him and them, consider the lilies of the field, 
note the songs of the catbird in the willow thicket, watch the poise and plunge of the kingfisher, and so spend all the day with nature and his own lazy thoughts. That is what he came for. Angling with him is only a pretense, an excuse to pay a visit to the great mother whom he so dearly loves; and if he carries home not so much as a scale, he is happy and content.

But how is it with him who comes stealing along with such light tread that it scarcely crushes the violets or shakes the dewdrops from the ferns, and casts his flies with such precise skill upon the very handsbreadth of water that gives most promise to his experienced eye; or drops his minnow with such care into the eddying pool, where he feels a bass must lie awaiting it. Eye and ear and every organ of sense are intent upon the sport for which he came. He sees only the images of the clouds, no branch but that which impedes him or offers cover to his stealthy approach. His ear is more alert for the splash of fishes than for bird songs. With his senses go all 
his thoughts, and float not away in day dreams.

Howsoever much he loves her, for the time while he hath rod in hand Mother Nature is a fish-woman, and he prays that she may deal generously with him. Though he be a parson, his thoughts tend not to religion; though a savant, not to science; though a statesman, not to politics; though an artist, to no art save the art of angling. So far removed from all these while he casts his fly or guides his minnow, how much further is his soul from all but the matter in hand when a fish has taken the one or the other, and all his skill is taxed to the utmost to bring his victim to creel. Heresy and paganism may prevail, the light of science be quenched, the country go to the dogs, pictures go unpainted, and statues unmoulded till he has saved this fish.

When the day is spent, the day's sport done, and he wends his way homeward with a goodly score, satisfied with himself and all the world besides, he may ponder on many things apart from that which has this day taken him by 
green fields and pleasant waters. Now he may brood his thoughts, and dream dreams; but while he angles, the complete angler is not a contemplative man.

The rivers roaring between their brimming banks; the brooks babbling over their pebbled beds and cross-stream logs that will be bridges for the fox in midsummer; the freed waters of lakes and ponds, dashing in slow beat of waves or quicker pulse of ripples against their shores, in voices monotonous but never tiresome, now call all who delight in the craft to go a-fishing.

With the sap in the aged tree, the blood quickens in the oldest angler's veins, whether he be of the anointed who fish by the book, or of the common sort who practice the methods of the forgotten inventors of the art.

The first are busy with rods and reels that are a pleasure to the eye and touch, with fly-books whose leaves are as bright with color as painted pictures, the others rummaging corner-cupboards for mislaid lines, searching the sheds for favorite 
poles of ash, ironwood, tamarack, or cedar, or perhaps the woods for one just budding on its sapling stump.

Each enjoys as much as the other the pleasant labor of preparation and the anticipation of sport, though perhaps that of the scientific angler is more æsthetic enjoyment, as his outfitting is the daintier and more artistic. But to each comes the recollection of past happy days spent on lake, river and brook, memories touched with a sense of loss, of days that can never come again, of comrades gone forever from earthly companionship.

And who shall say that the plebeian angler does not enter upon the untangling of his cotton lines, the trimming of his new cut pole, and the digging of his worms, with as much zest as his brother of the finer cast on the testing and mending of lancewood or split bamboo rod, the overhauling of silken lines and leaders, and the assorting of flies.

III

Considering the younger generation of anglers, one finds more enthusiasm among those who talk learnedly of all 
the niceties of the art. They scorn all fish not acknowledged as game. They plan more, though they may accomplish less than the common sort to whom all of fishing tackle is a pole, a line, and a hook. To them fishing is but fishing, and fish are only fish, and they will go for one or the other when the signs are right and the day propitious.

Descending to the least and latest generation of anglers, we see the conditions reversed. The youth born to rod and reel and fly is not so enthusiastic in his devotion to the sport as the boy whose birthright is only the pole that craftsman never fashioned, the kinky lines of the country store, and hooks known by no maker's name. For it is not in the nature of a boy to hold to any nicety in sport of any sort, and this one, being herein unrestrained, enters upon the art called gentle with all the wild freedom of a young savage or a halfgrown mink.

For him it is almost as good as going fishing, to unearth and gather in an old teapot the worms, every one of which is to his sanguine vision the promise of a 
fish. What completeness of happiness for him to be allowed to go fishing with his father or grandfather or the acknowledged great fisherman of the neighborhood, a good-for-nothing ne'er-do-well, but wise in all the ways of fish and their taking and very careful of and kind to little boys.

The high-hole never cackled so merrily, nor meadow lark sang sweeter, nor grass sprang greener nor water shone brighter than to the boy when he goes a-fishing thus accompanied. To him is welcome everything that comes from the waters, be it trout, bass, perch, bullhead, or sunfish, and he hath pride even in the abominable but toothsome eel and the uneatable bowfin.

Well, remembering that we were once boys and are yet anglers, though we seldom go a-fishing, we wish, in the days of the new springtide, to all the craft, whether they be of high or low degree, bent and cramped with the winter of age or flushed with the spring of life, pleasant and peaceful days of honest sport by all watersides, and full creels and strings and wythes. 
In the soft evenings of April when the air is full of the undefinable odor of the warming earth and of the incessant rejoicing of innumerable members of the many families of batrachians, one may see silently moving lights prowling along the low shores of shallow waters, now hidden by trunks of great trees that are knee-deep in the still water, now emerging, illuminating bolls and branches and flashing their.glimmering glades far across the ripples of wake and light breeze.

If one were near enough he could see the boat of the spearers, its bow and the intent figure of the spearman aglow in the light of the jack which flares a backward flame with its steady progress, and drops a slow shower of sparks, while the stern and the paddler sitting therein are dimly apparent in the verge of the gloom.

These may be honest men engaged in no illegal affair; they exercise skill of a certain sort; they are enthusiastic in the pursuit of their pastime, which is as fair as jacking deer, a practice upheld by 
many in high places; yet these who by somewhat similar methods take fish for sport and food are not accounted honest fishermen, but arrant poachers. If jacking deer is right, how can jacking fish be wrong? or if jacking fish be wrong, how can jacking deer be right? Verily, there are nice distinctions in the ethics of sport. 


\section{XVIII}

\section{FARMERS AND FIELD SPORTS}

"Happy the man whose only care A few paternal acres bound, Content to breathe his native air On his own ground."

Happier still is such a one who has a love for the rod and gun, and with them finds now and then a day's freedom from all cares by the side of the stream that borders his own acres and in the woods that crest his knolls or shade his swamp.

As a rule none of our people take so few days of recreation as the farmer. Excepting Sundays, two or three days at the county fair, and perhaps as many more spent in the crowd and discomfort of a cheap railroad excursion, are all that are given by the ordinary farmer to anything but the affairs of the farm. It is true that his outdoor life makes it less necessary for him than for the man whose office or shop work keeps him 
mostly indoors, to devote a month or a fortnight of each year to entire rest from labor. Indeed, he can hardly do this except in winter, when his own fireside is oftener the pleasantest place for rest. But he would be the better for more days of healthful pleasure, and many such he might have if he would so use those odd ones which fall within his year, when crops are sown and planted or harvested. A day in the woods or by the stream is better for body and mind than one spent in idle gossip at the village store, and nine times out of ten better for the pocket, though one come home without fin or feather to show for his day's outing. One who keeps his eyes and ears on duty while abroad in the field can hardly fail to see and hear something new, or, at least, more interesting and profitable than ordinary gossip, and the wear and tear of tackle and a few charges of ammunition wasted will cost less than the treats which are pretty apt to be part of a day's loafing.

Barring the dearth of the objects of his pursuit, the farmer who goes a-fishing and a-hunting should not be unsuccess80 
ful if he has fair skill with the rod and gun. For he. who knows most of the habits of fish and game will succeed best in their capture, and no man, except the naturalist and the professional fisherman and hunter, has a better chance to gain this knowledge than the farmer, whose life brings him into everyday companionship with nature. His fields and woods are the homes and haunts of the birds and beasts of venery, from the beginning of the year to its end, and in his streams many of the fishes pass their lives. By his woodside the quail builds her nest, and when the foam of blossom has dried away on the buckwheat field she leads her young there to feed on the brown kernel stranded on the coral stems. If he chance to follow his wood road in early June, the ruffed grouse limps and flutters along it before him, while her callow chicks vanish as if by a conjurer's trick from beneath his very footfall. A month later, grown to the size of robins, they will scatter on the wing from his path with a vigor that foretells the bold whir and the swiftness of their flight in their grown-up days, when they will stir 8 r 
the steadiest nerve, whether they hurtle from an October-painted thicket or from the blue shadows of untracked snow. No one is likelier to see and hear the strange wooing of the woodcock in the soft spring evenings, and to the farmer's ear first comes that assurance of spring, the wail of the Bartram's sandpiper returning from the South to breed in meadow and pasture, and then in hollow trees that overhang the river the wood ducks begin to spoil their holiday attire in the work and care of housekeeping. The fox burrows and breeds in the farmer's woods. The raccoon's den is there in ledge or hollow tree. The hare makes her form in the shadow of his evergreens, where she dons her dress of tawny or white to match the brown floor of the woods or its soft covering of snow. The bass comes to his river in May to spawn, the pike-perch for food, and the perch lives there, as perhaps the trout does in his brook.

All these are his tenants, or his summer boarders, and if he knows not something of their lives, and when and where to find them at home or in their favorite 
resorts, he is a careless landlord. His life will be the pleasanter for the interest he takes in theirs, and the skill he acquires in bringing them to bag and creel. 


\section{XIX}

\section{TO A TRESPASS SIGN}

Scene, $A$ Wood. An old man with a fishing-rod speaks:-

WHAT strange object is this which I behold, incongruous in its staring whiteness of fresh paint and black lettering, its straightness of lines and abrupt irregularity amid the soft tints and graceful curves of this sylvan scene? As I live, a trespass sign!

Thou inanimate yet most impertinent thing, dumb yet commanding me with most imperative words to depart hence, how dost thou dare forbid my entrance upon what has so long been my own, even as it is the birds' and beasts' and fishes', not by lease or title deed, but of natural right? Hither from time immemorial have they come at will and so departed at no man's behest, as have I since the happy days when a barefoot boy I cast my worm-baited hook among 
the crystal foam bells, or bearing the heavy burden of my grandsire's rusty flint-lock, I stalked the wily grouse in the diurnal twilight of these thickets.

Here was I thrilled by the capture of my first trout; here exulted over the downfall of my first woodcock; here, grown to man's estate, I learned to cast the fly; here beheld my first dog draw on his game, and here, year after year, till my locks have grown gray, have I come, sharp set with months of longing, to live again for a little while the carefree days of youth.

Never have I been bidden to depart but by storm or nightfall or satiety, until now thou confrontest me with thy impudent mandate, thou, thou contemptible, but yet not to be despised nor unheeded parallelogram of painted deal, with thy legal phrases and impending penalties; thou, the silent yet terribly impressive representative of men whose purses are longer than mine!

What is their right to this stream, these woods, compared with mine? Theirs is only gained by purchase, confirmed by scrawled parchment, signed and sealed; 
mine a birthright, as always I hoped it might be of my sons and my sons' sons. What to the usurpers of our rights are these woods and waters but a place for the killing of game and fish? They do not love, as a man the roof-tree whereunder he was born, these arches and low aisles of the woods; they do not know as I do every silver loop of the brook, every tree whose quivering reflection throbs across its eddies; its voice is only babble to their ears, the song of the pines tells them no story of bygone years.

Of all comers here, I who expected most kindly welcome am most inhospitably treated. All my old familiars, the birds, the beasts, and the fishes, may fly over thee, walk beneath thee, swim around thee, but to me thou art a wall that I may not pass.

I despise thee and spit upon thee, thou most impudent intruder, thou insolent sentinel, thou odious monument of selfishness, but I dare not lay hands upon thee and cast thee down and trample thee in the dust of the earth as thou shouldst of right be entreated. To rid myself of thy hateful sight, I can only 
turn my back upon thee and depart with sorrow and anger in my heart.

Mayst thou keep nothing but disappointment for the greedy wretches who set thee here. 


\section{XX}

A GENTLE SPORTSMAN

AlL the skill of woodcraft that goes to the making of the successful hunter with the gun, must be possessed by him who hunts his game with the camera. His must be the stealthy, panther-like tread that breaks no twig nor rustles the fallen leaves. His the eye that reads at a glance the signs that to the ordinary sight are a blank or at most are an untranslatable enigma. His a patience that counts time as nothing when measured with the object sought. When by the use and practice of these, he has drawn within a closer range of his timid game than his brother of the gun need attain, he pulls trigger of a weapon that destroys not, but preserves its unharmed quarry in the very counterfeit of life and motion. The wild world is not made the poorer by one life for his shot, nor 88 
nature's peace disturbed, nor her nicely adjusted balance jarred.

$\mathrm{He}$ bears home his game, wearing still its pretty ways of life in the midst of its loved surroundings, the swaying hemlock bough where the grouse perched, the bending ferns about the deer's couch, the dew-beaded sedges where the woodcock skulks in the shadows of the alders, the lichened trunks and dim vistas of primeval woods, the sheen of voiceless waterfalls, the flash of sunlit waves that never break.

His trophies the moth may not assail. His game touches a finer sense than the palate possesses, satisfies a nobler appetite than the stomach's craving, and furnishes forth a feast that, ever spread, ever invites, and never palls upon the taste.

Moreover, this gentlest of sportsmen is hampered by no restrictions of close time, nor confronted by penalties of trespass. All seasons are open for his bloodless forays, all woods and waters free to his harmless weapon.

Neither is he trammeled by any nice distinctions as to what may or may not 


\section{A GENTLE SPORTSMAN}

be considered game. Everything counts in his score. The eagle on his craggy perch, the high-hole on his hollow tree, are as legitimate game for him as the deer and grouse. All things beautiful and wild and picturesque are his, yet he kills them not, but makes them a living and enduring joy, to himself and all who behold them. 


\section{XXI}

JULY DAYS

The woods are dense with full-grown leafage. Of all the trees, only the basswood has delayed its blossoming, to crown the height of summer and fill the sun-steeped air with a perfume that calls all the wild bees from hollow tree and scant woodside gleaning to a wealth of honey gathering, and all the hive-dwellers from their board-built homes to a finer and sweeter pillage than is offered by the odorous white sea of buckwheat. Half the flowers of wood and fields are out of bloom. Herdsgrass, clover and daisy are falling before the mower. The early grain fields have already caught the color of the sun, and the tasseling corn rustles its broad leaves above the rich loam that the woodcock delights to bore.

The dwindling streams have lost their boisterous clamor of springtide and wim- 
ple with subdued voices over beds too shallow to hide a minnow or his poised shadow on the sunlit shallows. The sharp eye of the angler probes the green depths of the slowly swirling pools, and discovers the secrets of the big fish which congregate therein.

The river has marked the stages of its decreasing volume with many lines along its steep banks. It discloses the muskrat's doorway, to which he once dived so gracefully, but now must clumsily climb to. Rafts of driftwood bridge the shallow current sunk so low that the lithe willows bend in vain to kiss its warm bosom. This only the swaying trails of water-weeds and rustling sedges toy with now; and swift-winged swallows coyly touch. There is not depth to hide the scurrying schools of minnows, the half of whom fly into the air in a curving burst of silver shower before the rush of a pickerel, whose green and mottled sides gleam like a swift-shot arrow in the downright sunbeams.

The sandpiper tilts along the shelving shore. Out of an embowered harbor a wood duck convoys her fleet of duck- 
lings, and on the ripples of their wake the anchored argosies of the water lilies toss and cast adrift their cargoes of perfume. Above them the green heron perches on an overhanging branch, uncouth but alert, whether sentinel or scout, flapping his awkward way along the ambient bends and reaches. With slow wing-beats he signals the coming of some more lazily moving boat, that drifts at the languid will of the current or indolent pull of oars that grate on the golden-meshed sand and pebbles.

Lazily, unexpectantly, the angler casts his line, to be only a convenient perch for the dragonflies; for the fish, save the affrighted minnows and the hungry pickerel, are as lazy as he: To-day he may enjoy to the full the contemplative man's recreation, nor have his contemplations disturbed by any finny folk of the under-water world, while dreamily he floats in sunshine and dappled shadow, so at one with the placid waters and quiet shores that wood duck, sandpiper, and heron scarcely note his unobtrusive presence.

No such easy and meditative pastime 93 
attends his brother of the gun who, sweating under the burden of lightest apparel and equipment, beats the swampy covers where beneath the sprawling alders and arching fronds of fern the woodcock hides. Not a breath stirs the murky atmosphere of these depths of shade, hotter than sunshine; not a branch nor leaf moves but with his struggling passage, or marking with a wake of waving undergrowth the course of his unseen dog.

Except this rustling of branches, sedges and ferns, the thin, continuous piping of the swarming mosquitoes, the busy tapping and occasional harsh call of a woodpecker, scarcely a sound invades'the hot silence, till the wake of the hidden dog ceases suddenly and the waving brakes sway with quickening vibrations into stillness behind him. Then, his master draws cautiously near, with gun at a ready and an unheeded mosquito drilling his nose, the fern leaves burst apart with a sudden shiver, and a woodcock, uttering that shrill unexplained twitter, upsprings in a halo of rapid wing-beats and flashes out of sight 
among leaves and branches. As quick, the heelplate strikes the alert gunner's shoulder, and, as if in response to the shock, the short unechoed report jars the silence of the woods. As if out of the cloud of sulphurous smoke, a shower of leaves flutter down, with a quicker patter of dry twigs and shards of bark, and among all these a brown clod drops lifeless and inert to mother earth.

A woodcock is a woodcock, though but three-quarters grown; and the shot one that only a quick eye and ready hand may accomplish; but would not the achievement have been more worthy, the prize richer, the sport keener in the gaudy leafage and bracing air of October, rather than in this sweltering heat, befogged with clouds of pestering insects, when every step is a toil, every moment a torture? Yet men deem it sport and glory if they do not delight in its performance. The anxious note and behavior of mother song-birds, whose poor little hearts are in as great a flutter as their wings concerning their half-grown broods, hatched coincidently with the woodcock, is proof enough to those who 
would heed it, that this is not a proper season for shooting. But in some northerly parts of our wide country it is woodcock now or never, for the birds bred still further northward are rarely tempted by the cosiest copse or half-sunned hillside of open woods to linger for more than a day or two, as they fare southward, called to warmer days of rest and frostless moonlit nights of feeding under kindlier skies.

While the nighthawk's monotonous cry and intermittent boom and the indistinct voice of the whippoorwill ring out in the late twilight of the July evenings, the alarmed, half-guttural chuckle of the grass plover is heard, so early migrating in light marching order, thin in flesh but strong of wing, a poor prize for the gunner whose ardor outruns his humanity and better judgment. Lean or fat, a plover is a plover, but would that he might tarry with us till the plump grasshoppers of August and September had clothed his breast and ribs with fatness. Well, let him go, if so soon he will. So let the woodcock go, to offer his best to more fortunate sportsmen. What 
does it profit us to kill merely for the sake of killing, and have to show therefor but a beggarly account of bones and feathers? Are there not grouse and quail and woodcock waiting for us, and while we wait for them can we not content ourselves with indolent angling by shaded streams in these melting days of July rather than contribute the blaze and smoke of gunpowder to the heat and murkiness of midsummer? If we must shed blood let us tap the cool veins of the fishes, not the hot arteries of brooding mother birds and their fledgelings. 


\section{XXII}

CAMPING OUT

"CAmping out" is becoming merely a name for moving out of one's permanent habitation and dwelling for a few weeks in a well-built lodge, smaller than one's home, but as comfortable and almost as convenient; with tables, chairs and crockery, carpets and curtains, beds with sheets and blankets on real bedsteads, a stove and its full outfit of cooking utensils, wherefrom meals are served in the regular ways of civilization. Living in nearly the same fashion of his ordinary life, except that he wears a flannel shirt and a slouch hat, and fishes a little and loafs more than is his ordinary custom, our "camper" imagines that he is getting quite close to the primitive ways of hunters and trappers; that he is living their life with nothing lacking but the rough edges, which he has in98 
geniously smoothed away. $\mathrm{He}$ is mistaken. In ridding himself of some of its discomforts, he has lost a great deal of the best of real camp life ; the spice of small adventure, and the woodsy flavor that its half-hardships and makeshift appliances give it. If one sleeps a little cold under his one blanket on his bed of evergreen twigs, though he does not take cold, he realizes in some degree the discomfort of Boone's bivouac when he cuddled beside his hounds to keep from freezing - and feels slightly heroic. His slumbers are seasoned with dreams of the wild woods, as the balsamic perfume of his couch steals into his nostrils; his companions' snores invade his drowsy senses as the growl of bears, and the thunderous whir of grouse bursting out of untrodden thickets. When he awakes in the gray of early morning he finds that the few hours of sleep have wrought a miracle of rest, and he feels himself nearer to nature when he washes his face in the brook, than when he rinses off his sleepiness in bowl or basin. The water of the spring is colder and has a 
finer flavor when he drinks it from a birch bark cup of his own making. Tea made in a frying-pan has an aroma never known to such poor mortals as brew their tea in a teapot, and no mill ever ground such coffee as that which is tied up in a rag and pounded with a stone or hatchet-head. A sharpened stick for a fork gives a zest to the bit of pork "frizzled " on as rude a spit and plattered on a clean chip or a sheet of bark, and no fish was ever more toothsome than when broiled on a gridiron improvised of green wands or roasted Indian fashion in a cleft stick.

What can make amends for the loss of the camp-fire, with innumerable pictures glowing and shifting in its heart, and conjuring strange shapes out of the surrounding gloom, and suggesting unseen mysteries that the circle of darkness holds behind its rim? How are the wells of conversation to be thawed out by a black stove, so that tales of hunters' and fishers' craft and adventure shall flow till the measure of man's belief is overrun? How is the congenial spark of true companionship to be kindled when people 100 
brood around a stove and light their pipes with matches, and not with coals snatched out of the camp-fire's edge, or with twigs that burn briefly with baffling flame?

But it will not be long before it will be impossible to get a taste of real camping without taking long and expensive journeys, for every available rod of lake shore and river bank is being taken up and made populous with so-called camps, and the comfortable freedom and seclusion of a real camp are made impossible there. One desiring that might better pitch his tent in the back woodlot of a farm than in any such popular resort. This misnamed camping out has become a fashion which seems likely to last till the shores are as thronged as the towns, and the woods are spoiled for the real campers, whom it is possible to imagine seeking in the summers of the future a seclusion in the cities that the forests and streams no longer can give them.

Yet, let it be understood that makebelieve camping is better than no camp. ing. It cannot but bring people into 
more intimate relations with nature than they would be if they stayed at home, and so to better acquaintance with our common mother, who deals so impartially with all her children.

IO2 


\section{XXIII}

THE CAMP-FIRE

IF " the open fire furnishes the room," the camp-fire does more for the camp. It is its life - a life that throbs out in every flare and flicker to enliven the surroundings, whether they be the trees of the forest, the expanse of prairie, shadowed only by clouds and night, or the barren stretch of sandy shore. Out of the encompassing gloom of all these, the camp-fire materializes figures as real to the eye as flesh and blood. It peoples the verge of darkness with grotesque forms, that leap and crouch and sway with the rise and fall and bending of the flame to the wind, and that beckon the fancy out to grope in the mystery of night.

Then imagination soars with the updrift of smoke and the climbing galaxy of fading sparks, to where the steadfast stars shine out of the unvisited realm that only imagination can explore. 
The camp-fire gives an expression to the human face that it bears in no other light, a vague intentness, an absorption in nothing tangible; and yet not a faraway look, for it is focused on the flame that now licks a fresh morsel of wood, now laps the empty air; or it is fixed on the shifting glow of embers, whose blushes flush or fade under their ashen veil. It is not the gaze of one who looks past everything at nothing, or at the stars or the mountains or the far-away sea-horizon; but it is centred on and revealed only by the camp-fire. You wonder what the gazer beholds - the past, the future, or something that is neither; and the uncertain answer you can only get by your own questioning of the flickering blaze.

As the outers gather around this cheerful centre their lips exhale stories of adventure by field and flood, as naturally as the burning fuel does smoke and sparks, and in that engendering warmth, no fish caught or lost, no buck killed or missed, suffers shrinkage in size or weight, no peril is lessened, no tale shorn 
of minutest detail. All these belong to the camp-fire, whether it is built in conformity to scientific rules or piled clumsily by unskilled hands. What satisfaction there is in the partnership of building this altar of the camp, for though a master of woodcraft superintends, all may take a hand in its erection; the youngest and the weakest may contribute a stick that will brighten the blaze.

What hospitality the glow of the camp-fire proclaims in inviting always one more to the elastic circle of light and warmth, that if always complete, yet expands to receive another guest. A pillar of cloud by day, of fire by night, it is a beacon that guides the wanderer to shelter and comfort.

The Indian weed has never such perfect flavor as when, contending with heat and smoke, one lights his pipe with a coal or an elusive flame, snatched from the embers of the camp-fire, and by no other fireside does the nicotian vapor sa soothe the perturbed senses, bring such lazy contentment, nor conjure such pleas- 
ant fancies out of the border of dream. land.

There is no cooking comparable with that which the camp-fire affords. To whatever is boiled, stewed, roasted, broiled or baked over its blaze, in the glow of its embers or in its ashes, it imparts a distinctive woodsy flavor that it distills out of itself or draws from the spiced air that fans it; and the aroma of every dish invites an appetite that is never disappointed if the supply be large enough.

It cannot be denied that the camp stove gives forth warmth and, with more comfort to the cook, serves to cook food of such tame flavor as one may get at home. But though the serviceable little imp roar till its black cheeks glow red as winter berries, it cannot make shanty or tent a camp in reality or impart to an outing its true flavor. This can only be given by the generous camp-fire, whose flames and embers no narrow walls inclose, whose hearth is on every side, whose chimney is the wide air. 


\section{XXIV}

\section{A RAINY DAY IN CAMP}

THE plans of the camper, like those of other men, "gang aft agley." - The morrow, which he proposed to devote to some long-desired hunting or fishing trip, is no more apt to dawn propitiously on him than on the husbandman, the mariner, or any other mortal who looks to the weather for special favor. On the contrary, instead of the glowing horizon and the glory of the sunburst that should usher in the morning, the slow dawn is quite apt to have the unwelcome accompaniment of rain.

The hearing, first alert of the drowsy senses, catches the sullen patter of the drops on tent or shanty, their spiteful, hissing fall on the smouldering embers of the camp-fire, and with a waft of damp earth and herbage stealing into his nostrils, the disappointed awakener turns fretfully under his blanket, then crawls 
forth to have his lingering hope smothered in the veil of rain that blurs the landscape almost to annihilation.

$\mathrm{He}$ mutters anathemas against the weather, then takes the day as it has come to him, for better or for worse. First, to make the best of it, he piles high the camp-fire, and dispels with its glow and warmth some cubic feet of gloom and dampness. Then he sets about breakfast-making, scurrying forth from shelter to fire, in rapid culinary forays, battling with the smoke, for glimpses of the contents of kettle and pan. His repast is as pungent with smoke as the strong waters of Glenlivat, but if that is valued for its flavor of peatreek, why should he scorn food for the like quality?

Then if he delights in petty warfare with the elements, to bide the pelting of the rain, to storm the abatis of wet thickets and suffer the sapping and mining of insidious moisture, he girds up his loins and goes forth with rod or gun, as his desire of conquest may incline him.

But if he has come to his outing with the intention of pursuing sport with 108 
bodily comfort, he is at once assured that this is unattainable under the present conditions of the weather. Shall he beguile the tediousness of a wet day in camp with books and papers?

Nay, if they were not left behind in the busy, plodding world that he came here to escape from, they should have been. He wants nothing here that reminds him of traffic or politics; nothing of history, for now he has only to do with the present; nothing of travel, for his concern now is only with the exploration of this wild domain. He does not wish to be bothered with fiction, idealized reality is what he desires. Neither does he care for what other men have written of nature. Her book is before him and he may read it from first hands.

Looking forth from his snug shelter on the circumscribed landscape, he marvels at the brightness of a distant yellow tree that shines like a living flame through the veil of mist. The blaze of his sputtering camp-fire is not brighter. $\mathrm{He}$ notices, as perhaps he never did before, how distinctly the dark ramage of the branches is traced 
among the brilliant leaves, as if with their autumnal hues they were given transparency. Some unfelt waft of the upper air casts aside for a moment the curtain of mist and briefly discloses a mountain peak, radiant with all the hues of autumn, and it is as if one were given, as in a dream, a glimpse of the undiscovered country. He realizes a dreamy pleasure in watching the waves coming in out of the obscurity and dashing on the shore, or pulsing away in fading leaden lines into the mystery of the wrack.

In the borders of the mist the ducks revel in the upper and nether wetness, and with uncanny laughter the loon rejoices between his long explorations of the aquatic depth. A mink, as heedless of rain as the waterfowl, comes stealing along the shore, thridding the intricacies of driftwood and web of wave-washed tree roots, often peering out in inquisitive examination of the quiet camp. Less cautious visitors draw nearer the friendly chickadee, hanging from the nearest twig; the nuthatch, sounding his penny trumpet, accompanied by the 
tap of the woodpecker, as one creeps down, the other up a tree trunk; the scolding jays, making as noisy protest over human intrusion as if they had just discovered it; a saucy squirrel, scoffing and jeering, till tired of his raillery he settles down to quiet nut-rasping under shelter of his tail.

There are unseen visitors, too: woodmice, astir under cover of the fallen leaves, and, just discernible among the patter of the falling rain and of the squirrels' filings, footfalls unidentified, till a ruffed grouse starts new showers from the wet branches in the thunder of his flight.

Narrowed to the width of tent or shanty front, the background but a pallid shroud of mist, the landscape yet holds much for pleasant study. But if the weather-bound camper exhausts this or tires of it, he may turn to gun-cleaning or tackle-mending. If a guide be with him, he can listen to his stories of hunting, fishing, and adventure, or learn woodcraft of him and the curious ways of birds and beasts. $\mathrm{He}$ may fashion birch-bark camp-ware, dippers, cups, and 
boxes, or whittle a paddle from a smoothrifted maple. If he is of artistic turn, he can pleasantly devote an hour to etching pictures on the white under surface of the fungus that grows on decaying trees, and so provide himself with reminders of this rainy day in camp.

So, with one and another pastime, he whiles away the sunless day, which, almost before he has thought of it, merges into the early nightfall, and he is lulled to sleep by the same sound that wakened him, the drip and patter of the rain. And when he looks back to these days of outing he may count this, which dawned so unpropitiously, not the least pleasant and profitable among them, and mark with a white stone the rainy day in camp. 


\section{XXV}

\section{AUGUST DAYS}

WITH such unmistakable signs made manifest to the eye and ear the summer signals its fullness and decline, that one awakening now from a sleep that fell upon him months ago might be assured of the season with the first touch of awakening.

To the first aroused sense comes the long-drawn cry of the locust fading into silence with the dry, husky clap of his wings; the changed voice of the song birds, no more caroling the jocund tunes of mating and nesting time, but plaintive with the sadness of farewell.

The bobolink has lost, with his pied coat, the merry lilt that tinkled so continually over the buttercups and daisies of the June meadows; rarely the song sparrow utters the trill that cheered us in the doubtful days of early spring. The bluebird's abbreviated carol floats 
down from the sky as sweet as then, but mournful as the patter of autumn leaves. The gay goldfinch has but three notes left of his June song, as he tilts on the latest blossoms and fluffy seeds of the thistles. The meadowlark charms us no more with his long-drawn melody, but with one sharp, insistent note he struts in the meadow stubble or skulks among the tussocks of the pasture and challenges the youthful gunner. What an easy shot that even, steady flight offers, and yet it goes onward with unfaltering rapid wing-beats, while the gun thunders and the harmless shot flies behind him. The flicker cackles now no more as when he was a jubilant new comer, with the new-come spring for his comrade, but is silent or only yelps one harsh note as he flashes his golden wings in loping flight from fence-stake to ant-hill.

The plover chuckles while he lingers at the bounteous feast of grasshoppers, but never pierces the August air with the long wail that proclaimed his springtime arrival. After nightfall, too, is heard his chuckling call fluttering down 
from the aerial path, where he wends his southward way, high and distinct above the shrill monotony of crickets and August pipers. The listening sportsman may well imagine that the departing bird is laughing at him as much as signaling his course to companion wayfarers.

The woodland thrushes' flutes and bells have ceased to breathe and chime, only the wood pewee keeps his pensive song of other days, yet best befitting those of declining summer.

The trees are dark with ripened leafage ; out of the twilight of the woodside glow the declining disks of wild sunflowers and shine the rising constellations of asters. The meadow sides are gay with unshorn fringes of goldenrod and willow-herb, and there in the corners of the gray fences droop the heavy clusters of elderberries, with whose purple juice the flocking robins and the young grouse, stealing from the shadowed copses along this belt of shade, dye their bills.

The brook trails its attenuated thread out of the woodland gloom to gild its 
shallow ripples with sunshine and redden them with the inverted flames of the cardinals that blaze on the sedgy brink. Here the brown mink prowls with her lithe cubs, all unworthy yet of the trapper's skill, but tending toward it with growth accelerated by full feasts of poolimpounded minnows. Here, too, the raccoon sets the print of his footsteps on the muddy shores as he stays his stomach with frogs and sharpens his appetite with the hot sauce of Indian turnip while he awaits the setting of his feast in the cornfields. The hounds are more impatient than he for the opening of his midnight revel, and tug at their chains and whimper and bay when they hear his querulous call trembling through the twilight. They are even fooled to melodiously mournful protest when their ears catch the shriller quaver of the screech owl's note.

The woodcock skulks in the bordering alders, and when forced to flight does so with a stronger wing than when a month ago his taking off was first legally authorized. Another month will make him worthier game; and then, too, the II 6 
ruffed grouse need not be spared a shot, as full grown and strong of pinion he bursts from cover; nor need the wood duck, now but a vigorous bunch of pin feathers, be let go untried or unscathed, when from his perch on a slanted log or out of a bower of rushes he breaks into the upper air with startling flutter of wings and startled squeak of alarm.

Summer wanes, flowers fade, bird songs falter to mournful notes of farewell; but while regretfully we mark the decline of these golden days, we remember with a thrill of expectation that they slope to the golden days of autumn, wherein the farmer garners his latest harvest, the sportsman his first worthy harvest, and that to him that waits, come all things, and even though he waits long, may come the best. 


\section{XXVI}

\section{A VOYAGE IN THE DARK}

A FEw days ago, a friend who is kind and patient enough to encumber himself with the care of a blind man and a boy . took me and my twelve-year-old a-fishing. It was with a fresh realization of my deprivation that I passed along the watery way once as familiar as the dooryard path, but now shrouded for me in a gloom more impenetrable than the blackness of the darkest night. I could only guess at the bends and reaches as the south wind blew on one cheek or the other, or on my back, only knowing where the channel draws near the shore upon which the Indians encamped in the old days by the flutter of leaves overbearing the rustle of rushes. By the chuckle of ripples under the bow, I guessed when we were in midchannel ; by the entangled splash of an oar, when we approached the reedy border where the water-lilies rode at an- 
chor, and discharged their subtle freight of perfume as they tossed in our wake. I knew by his clatter, drawing nearer only with our progress, that a kingfisher was perched on a channel-side fishingstake, used in turn by him and bigger but not more skillful fishers. I heard his headlong plunge, but whether successful or not the ensuing clatter did not tell me, for he has but one voice for all expressions. Yet as his rattling cry was kept up till the rough edge of its harshness was worn away in receding flight, I fancied he was proclaiming an unusually successful achievement. For the sake of his reputation, he would never make such a fuss over a failure, unless he was telling, as we do, of the big fish he just missed catching. At any rate, I wished him good luck, for who would begrudge a poor kingfisher such little fish as he must catch! They would need years of growth to make them worth our catching or bragging over the loss of, and by that time we may be done with fishing.

Suddenly there was a roar of multitudinous wings as a host of redwings up- 
burst from springing and swaying wild rice stalks, all of which I saw through the blackness illumined for an instant by memory, - the dusky cloud uprising like the smoke of an explosion, the bent rice springing up beneath its lifted burden, the dull-witted or greedy laggards dribbling upward to join the majority. My companions exclaimed in one voice at the rare sight of a white bird in the flock, and by the same light of memory I also saw it as I saw one in an autumn forty years ago, when, with my comrade of those days, I came "daown the crik" duck-shooting, or trolling as to-day. Again and again we saw this phenomenal bird like a white star twinkling through a murky cloud. The fitful gleam was seen day after day, till the north wind blew him and his cloud away southward.

The pother of the blackbirds overhead disturbed the meditations of a bittern, who, with an alarmed croak, jerked his ungainly form aloft in a flurry of awkward wing - beats, and went sagging across the marshes in search of safer seclusion. I wished that he might find it, and escape the ruthless gunners that 
will presently come to desolate these marshes. Very different from his uprising was that of a pair of wood ducks, revealing their unsuspected presence with startling suddenness, as they sprang from water to air with a splash and whistle of rapid wings and their squeaking alarm cry, and then flew swiftly away, the sibilant wing-beats pulsing out in the distance. These, too, I wished might safely run the gauntlet of all the guns that will be arrayed against them when the summer truce is broken. If I had not been mustered out, or if my boy were mustered in, no doubt I should feel differently toward the inhabitants of these marshes. Compulsory abstinence makes one exceedingly virtuous, and because I am virtuous there shall be no cakes and ale for any one.

The absence of the rail's cackle was noticeable, a clamor that used to be provoked at this season by every sudden noise. We never got sight of the "ma'sh chickens" as they skulked among the sedges; and when the birds were pressed to flight, rarely caught more than a fleeting glimpse as they 


\section{A VOYAGE IN THE DARK}

topped the rushes for an instant, and dropped again into the mazes of the marsh. But they were always announcing a numerous if invisible presence where now not one answered to our voices or the noise of our oars.

All this while our trolling gear was in tow: the boy's a "phantom minnow" bristling with barbs, a veritable porcupine fish; mine a fluted spoon. The larger fish seemed attracted by the better imitation, or perhaps age and experience had given them discernment to shun the other more glaring sham, and the best of them went to the boy's score; but the unwise majority of smaller fish were evidently anxious to secure souvenir spoons of Little Otter, and in consequence of that desire I was "high hook" as to numbers. They were only pickerel at best, though some of them, bearing their spots on a green ground, are honored with the name of "maskalonge" by our fishermen. A scratch of the finger-nail across the scaly gill-cover gives proof enough to convince even a blind man of the worthlessness of this claim to distinction. 
Once I enjoyed an exaltation of spirit only to suffer humiliation. There was a tug at the hooks, so heavy that my first thought was of a snag, and I was on the point of calling out to my friend to stop rowing. Then there was a slight yielding, and the tremor that tells unmistakably of a fish. "Now," said I, with my heart but a little way back of my teeth, "I am fast to something like a fish, but I shall never be able to boat him. $\mathrm{He}$ is too big to lift out with the hooks, and I can't see to get him by the gills, and so I shall lose him." As he came in slowly, stubbornly fighting against every shortening inch of line, I almost wished he had not been hooked at all only to be lost at last. When, after a time, my fish was hauled near the boat and in sight of my companions, my catch proved to be no monster, but a pickerel of very ordinary size hooked by the belly, and so my hopes and fears vanished together.

I think distances are magnified to the blind, for it seemed twice as far as it did of old from the East Slang to the South 
Slang, as we passed these oddly named tributaries of Little Otter.

At last I sniffed the fragrance of cedars and heard the wash of waves on the southward-slanted shore of Garden Island, and these informed me we were at the lake. In confirmation thereof was the testimony of my companions, given out of their light to my darkness, of an eagle's royal progress through his ethereal realm, making inspection of his disputed earthly possession. I was glad to know that his majesty had escaped the republican regicides who haunt the summer shores.

We made a difficult landing on the - mainland, on the oozy shore of mixed

: sawdust and mud, and followed the old

- trail to the old camping ground under the rocks, a place full of pleasant memories for the elder two of our trio, and offering to the boy the charms of freshness and discovery. For him the cliff towered skyward but little below the eagle's flight; its tiny caves were unexplored mysteries, their coral-beaded curtains of Canada yew and delicate netting of mountain-fringe strange foreign growths. 
Through his undimmed eyes I had glimpses of those happy shores whereon the sun always shines and no cloud arises beyond. What a little way behind they seem in the voyage that has grown wearisome, and yet we can never revisit them for a day nor for an hour, and it is like a dream that we ever dwelt there.

Bearing with us from this port something not marketable nor even visible, yet worth carrying home, we reëmbarked, and the wind, blowing in my face, informed me we were homeward bound. One after another, we passed five boats of fishing parties tied up at as many stakes, the crews pursuing their pastime with steadfast patience, as their intent silence proclaimed. To me they were as ships passed in the night. I had no other knowledge of them than this, except that my friend told me there was a fat woman in each boat, and that one of them boasted to us, with motherly pride, of a big pickerel caught by her little girl.

A blended hum of bumblebees droned in among us, and my companions re- 
marked that one of the aerial voyagers had boarded our craft, while I maintained there were two, which proved to be the fact; whereupon I argued that my ears were better than their eyes, but failed to convince them or even myself. I welcomed the bees as old acquaintances, who, in the duck-shooting of past years, always used to come aboard and bear us company for awhile, rarely alighting, but tacking from stem to stern on a cruise of inspection, till at last, satisfied or disappointed, they went booming out of sight and hearing over marshfuls of blue spikes of pickerel weed and white trinities of arrowhead. I cannot imagine why bees should be attracted to the barrenness of a boat, unless by a curiosity to explore such strange floating islands, though their dry wood promises neither leaf nor bloom.

I hear of people every year who forsake leafage and bloom to search the frozen desolation of the polar north for the Lord knows what, and I cease to wonder at the bees, when men so waste the summers that are given them to enjoy if they will but bide in them. 
We passed many new houses of the muskrats, who are building close to the channel this year in prophecy of continued low water. But muskrats are not infallible prophets, and sometimes suffer therefor in starvation or drowning. The labor of the night-workers was suspended in the glare of the August afternoon, and their houses were as silent as if deserted, though we doubted not there were happy households inside them, untroubled by dreams of famine or deluge, or possibly of the unmercifulness of man, though that seems an abiding terror with our lesser brethren. Winter before last the marshes were frozen to the bottom, blockading the muskrats in their houses, where entire families perished miserably after being starved to cannibalism. Some dug out through the house roofs, and wandered far across the desolate wintry fields in search of food. Yet nature, indifferent to all fates, has so fostered them since that direful season that the marshy shores are populous again with sedge-thatched houses.

As we neared our home port we met 
two trollers, one of whom lifted up for envious inspection a lusty pickerel. "He's as big as your leg," my friend replied to my inquiry concerning its dimensions, and in aid of my further inquisitiveness asked the lucky captor how much the fish would weigh. "Wal, I guess he ought to weigh abaout seven pounds," was answered, after careful consideration. We learned afterwards that its actual weight was nine pounds, and I set that man down as a very honest angler.

Presently our boat ran her nose into the familiar mire of well-named Mud Landing, and we exchanged oars for legs, which we plied with right good will, for a thunderstorm was beginning to bellow behind us. 


\section{XXVII}

THE SUMMER CAMP-FIRE

A THIN column of smoke seen rising lazily among the leafy trees and fading to a wavering film in the warm morning air or the hotter breath of noon, a flickering blaze kindling in the sultry dusk on some quiet shore, mark the place of the summer camp-fire.

It is not, like the great hospitable flare and glowing coals of the autumn and winter camp-fires, the centre to which all are drawn, about which the life of the camp gathers, where joke and repartee flash to and fro as naturally and as frequently as its own sparks fly upward, where stories come forth as continuously as the ever-rising volume of smoke.

Rather it is avoided and kept aloof from, held to only by the unhappy wretch upon whom devolves the task of tending the pot and frying-pan, and he 
hovers near it fitfully, like a moth about a candle, now backing away to mop his hot face, now darting into the torrid circle to turn a fish or snatch away a seething pot or sizzling pan. Now and then the curious and hungry approach to note with what skill or speed the cookery is progressing, but they are content to look on at a respectful distance and to make suggestions and criticisms, but not to interfere with aid. The epicurean smoker, who holds that the finest flavor of tobacco is evoked only by coal or blazing splinter, steals down upon the windward side and snatches a reluctant ember or an elusive flame that flickers out on the brink of the pipe bowl, but most who burn the weed are content now to kindle it with the less fervid flame of a match.

And yet this now uncomfortable necessity is still the heart of the camp, which without it would be but a halting place for a day, where one appeases hunger with a cold bite and thirst with draughts of tepid water, and not a temporary home where man has his own fireside, though he care not to sit near 
it, and feasts full on hot viands and refreshes himself with the steaming cup that cheers but not inebriates.

Its smoke drifted far through the woods may prove a pungent trail, scented out among the odors of balsams and the perfume of flowers that shall lead hither some pleasant stranger or unexpected friend, or its firefly glow, flashing but feebly through the gloaming, may be a beacon that shall bring such company. In its praise may also be said that the summer camp-fire demands no laborious feeding nor careful tending, is always a servant, seldom a master. 


\section{XXVIII}

\section{THE RACCOON}

SUMmer is past its height. The songless bobolink has forsaken the shorn meadow. Grain fields, save the battalioned maize, have fallen from gracefulness and beauty of bending heads and ripple of mimic waves to bristling acres of stubble. From the thriftless borders of ripening weeds busy flocks of yellowbirds in faded plumage scatter in sudden flight at one's approach like upblown flurries of dun leaves. Goldenrod gilds the fence-corners, asters shine in the dewy borders of the woods, sole survivors of the floral world save the persistent bloom of the wild carrot and succory - flourishing as if there had never been mower or reaper - and the white blossoms of the buckwheat crowning the filling kernels. The fervid days have grown preceptibly shorter, the lengthening nights have a chilly autumnal 
flavor, and in the cool dusk the katydids call and answer one to another out. of their leafy tents, and the delicate green crickets that Yankee folks call August pipers play their monotonous tune. Above the katydid's strident cry and the piper's incessant notes, a wild tremulous whinny shivers through the gloom at intervals, now from a distant field or wood, now from the near orchard. One listener will tell you that it is only a little screech owl's voice, another that it is the raccoon's rallying cry to a raid on the cornfield. There is endless disputation concerning it and apparently no certainty, but the raccoon is wilder than the owl, and it is pleasanter to believe that it is his voice that you hear.

The corn is in the milk; the feast is ready. The father and mother and well grown children, born and reared in the cavern of a ledge or hollow tree of a swamp, are hungry for sweets remembered or yet untasted, and they are gathering to it, stealing out of the thick darkness of the woods and along the brookside in single file, never stopping to 
dig a fiery wake-robin bulb nor to catch a frog nor harry a late brood of groundnesting birds, but only to call some laggard, or distant clansfolk. So one fancies, when the quavering cry is repeated and when it ceases, that all the freebooters have gained the cornfield and are silent with busy looting. Next day's examination of the field may confirm the fancy with the sight of torn and trampled stalks and munched ears. These are the nights when the coon hunter is abroad and the robbers' revel is likely to be broken up in a wild panic.

Hunted only at night, to follow the coon the boldest rider must dismount, yet he who risks neck and limbs, or melts or freezes for sport's sake, and deems no sport manly that has not a spice of danger or discomfort in it, must not despise this humble pastime for such reason.

On leaving the highway that leads nearest to the hunting ground, the way of the coon hunters takes them, in darkness or feeble lantern light, over rough and uncertain footing, till the cornfield's edge is reached and the dogs cast off. 
Away go the hounds, their course only indicated by the rustling of the corn leaves, as they range through the field, until one old truth-teller gives tongue on the track of a coon who perhaps has brought his whole family out on a nocturnal picnic. The hounds sweep straight away, in full cry, on the hot scent to hill or swamp, where their steadfast baying proclaims that the game is treed.

Then follows a pell-mell scramble toward the musical uproar. Stones, cradle knolls, logs, stumps, mud holes, brambles and all the inanimate enemies that lie in wait for man when he hastens in the dark, combine to trip, bump, bruise, sprain, scratch, and bemire the hurrying hunters.

Then when all have gathered at the centre of attraction, where the excited hounds are raving about the boll of some great tree, the best and boldest climber volunteers to go aloft into the upper darkness and shake the quarry down or shoot him if may be. If he succeeds in accomplishing the difficult task, what a mêlée ensues when the coon crashes through the branches to the ground and 
becomes the erratic centre of the wild huddle of dogs and men.

Fewer voices never broke the stillness of night with sounds more unearthly than the medley of raging, yelping, growling, cheering, and vociferous orders given forth by dogs, coon, and hunters, while hillside and woodland toss to and fro a more discordant badinage of echo. The coon is not a great beast, but a tough and sharp-toothed one, who carries beneath his gray coat and fat ribs a stout heart and wonderful vitality; and a tussle with a veteran of the tribe of cornfield robbers tests the pluck of the dogs.

If the coon takes refuge in a tree too tall and limbless for his pursuers to climb, there is nothing for them but to keep watch and ward till daylight discovers him crouched on his lofty perch. A huge fire enlivens the long hours of guard keeping. A foraging party repairs to the nearest cornfield for roasting ears, and the hunters shorten the slow nighttide with munching scorched corn, sauced by joke and song and tales of the coon hunts of bygone years. 
The waning moon throbs into view above a serrated hill-crest, then climbs the sky, while the shadows draw eastward, then pales in the dawn, and when it is like a blotch of white cloud in the zenith, a sunrise gun welcomes day and brings the coon tumbling to earth. Or perhaps not a coon, but some vagrant house cat is the poor reward of the long watch. Then the weary hunters plod homeward to breakfast and to nail their trophies to the barn door.

When the sweet acorns, dropping in the frosty night, tempt the coon to a later feast, there is as good sport and primer peltry. In any of the nights wherein this sport may be pursued, the man of lazy mould and contemplative mind loves best the hunt deemed unsuccessful by the more ardent hunters, when the hounds strike the trail of a wandering fox and carry a tide of wild music, flooding and ebbing over valley and hilltop, while the indolent hunter reclines at ease, smoking his pipe and listening, content to let more ambitious hunters stumble over ledges and wallow through swamps. 
When winter begins, the coon retires for a long and comfortable sleep, warmly clothed in fur and fat. A great midwinter thaw awakens him, fooled out of a part of his nap by the siren song of the south wind, and he wanders forth in quest of something. If food, he never finds it, and as far as I have been able to determine, does not even seek it. I should imagine, reading the record of his journey as he prints it in his course from hollow tree or hollow ledge to other hollow trees and hollow ledges, that he had been awakened to a sense of loneliness and was seeking old friends in familiar haunts, with whom to talk over last year's cornfield raids and frogging parties in past summer nights - perchance to plan future campaigns. Or is it an inward fire and no outward warmth that has thawed him into this sudden activity? Has he, like many of his biggers and betters, gone a-wooing in winter nights?

At such times the thrifty hunter who has an eye more to profit and prime peltry than to sport, goes forth armed only with an axe. Taking the track of the 138 
wanderers, he follows it to their last tarrying place. If it be a cave, they are safe except from the trap when they come forth to begin another journey; but if it is a hollow tree, woe betide the poor wretches. The hunter saps the foundation of their castle, and when it crashes to its fall he ignominiously knocks the dazed inmates on the head. It is fashionable for others to wear the coat which becomes the raccoon much better than them and which once robbed of he can never replace.

During the spring and early summer little is seen of the raccoon. His tracks may be found on a sandy shore or margin of a brook and occasionally his call can be heard, if indeed it be his, but beyond these he gives little evidence of his existence. There must be nocturnal excursions for food, but for the most part old and young abide in their rocky fortress or wooden tower. They are reported to be a playful family, and the report is confirmed by the pranks of domesticated members of it. Sometimes there will be found in one of their ravaged homes a rounded gnarl worn smooth with much 
handling or pawing, the sole furniture of the house and evidently a plaything.

This little brother of the bear is one of the few remaining links that connect us with the old times, when there were trees older than living men, when all the world had not entered for the race to gain the prize of wealth, or place, or renown; when it was the sum of all happiness for some of us to "go a-coonin'." It is pleasant to see the track of this midnight prowler, this despoiler of cornfields, imprinted in the mud of the lane or along the soft margin of the brook, to know that he survives, though he may not be the fittest. When he has gone forever, those who outlive him will know whether it was his quavering note that jarred the still air of the early fall evenings or if it was only the voice of the owl - if he too shall not then have gone the inevitable way of all the wild world. 


\section{XXIX}

THE RELUCTANT CAMP-FIRE

The depressing opposite of the fire that is the warm heart of the camp is the pile of green or rain-soaked fuel that in spite of all coaxing and nursing refuses to yield a cheerful flame. Shavings from the resin-embalmed heart of a dead pine and scrolls of birch bark fail to enkindle it to more than flicker and smoke, while the wet and hungry campers brood forlornly over the cheerless centre of their temporary home, with watery eyes and souls growing sick of camp life.

Night is falling, and the shadows of the woods thicken into solid gloom that teems with mysterious horrors, which stretch their intangible claws through the darkness to chill the backs of the timid with an icy touch, and the silence is terrible with unuttered howlings of imaginary beasts.

Each one is ready to blame the other for the common discomfort, and all, the 
high priest, who so far fails to kindle the altar fire. $\mathrm{He}$ is an impostor, who should be smothered in the reek of his own failure. Yet, as the group regard him with unkind glances and mutterings of disapproval, he perseveres, feeding the faint flame with choice morsels of fat wood and nursing it with his breath, his bent face and puffed cheeks now a little lightened, now fading into gloom, till suddenly the sullenness of the reluctant fuel is overcome, wings of flame flutter up the column of smoke, and the black pile leaps into a lurid tower of light, from whose peak a white banner of smoke flaunts upward, saluted by the waving boughs that it streams among.

Tent and shanty, familiar trees, and moving figures with their circle of grotesque, dancing shadows, spring into sudden existence out of the blank darkness. The magic touch of the firelight dispels every sullen look, warms every heart to genial comradeship; jokes flash back and forth merrily, and the camp pulses again with reawakened cheerful life. Verily, fire worketh wonders in divers ways. 


\section{$\mathrm{XXX}$}

\section{SEPTEMBER DAYS}

September days have the warmth of summer in their briefer hours, but in their lengthening evenings a prophetic breath of autumn. The cricket chirps in the noontide, making the most of what remains of his brief life ; the bumblebee is busy among the clover blossoms of the aftermath; and their shrill cry and dreamy hum hold the outdoor world above the voices of the song birds, now silent or departed.

What a little while ago they were our familiars, noted all about us in their accustomed haunts - sparrow, robin, and oriole, each trying now and then, as if to keep it in memory, a strain of his springtime love song, and the cuckoo fluting a farewell prophecy of rain. The bobolinks, in sober sameness of traveling gear, still held the meadowside thickets of weeds; and the swallows sat in sedate 
conclave on the barn ridge. Then, looking and listening for them, we suddenly become aware they are gone; the adobe city of the eave-dwellers is silent and deserted; the whilom choristers of the sunny summer meadows are departed to a less hospitable welcome in more genial climes. How unobtrusive was their exodus. We awake and miss them, or we think of them and see them not, and then we realize that with them summer too has gone.

This also the wafted thistledown and the blooming asters tell us, and, though the woods are dark with their latest greenness, in the lowlands the gaudy standard of autumn is already, displayed. In its shadow the muskrat is thatching his winter home, and on his new-shorn watery lawn the full-fledged wild duck broods disport in fullness of feather and strength of pinion. Evil days are these of September that now befall them. Alack, for the callow days of peaceful summer, when no honest gunner was abroad, and the law held the murderous gun in abeyance, and only the keel of the unarmed angler rippled the still 
channel. Continual unrest and abiding fear are their lot now and henceforth, till spring brings the truce of close time to their persecuted race.

More silently than the fisher's craft the skiff of the sportsman now invades the rush-paled thoroughfares. Noiseless as ghosts, paddler and shooter glide along the even path till, alarmed by some keener sense than is given us, up rise wood duck, dusky duck, and teal from their reedy cover. Then the ready gun belches its thunder, and suddenly consternation pervades the marshes. All the world has burst forth in a burning of powder. From end to end, from border to border, the fenny expanse roars with discharge and echo, and nowhere within it is there peace or rest for the sole of a webbed foot. Even the poor bittern and heron, harmless and worthless, flap to and fro from one to another now unsafe retreat, in constant danger of death from every booby gunner who can cover their slow flight.

The upland woods, too, are awakened from the slumber of their late summer days. How silent they had grown when 
their songsters had departed, rarely stirred but by the woodpecker's busy hammer, the chatter and bark of squirrels, and the crows making vociferous proclamation against some winged or furred enemy. The grouse have waxed fat among the border patches of berry bushes, rarely disturbed in the seclusion of the thickets but by the soft footfall of the fox, the fleeting shadow of a cruising hawk, and the halloo of the cowboy driving home his herd from the hillside pasture. Now come enemies more relentless than beast or bird of prey, a sound more alarming than the cowboy's distant call - man and his companion the dog, and the terrible thunder of the gun. A new terror is revealed to the young birds, a half-forgotten one brought afresh to the old. The crows have found fresh cause for clamor, and the squirrels lapse into a silence of fear.

Peace and the quietness of peace have departed from the realm of the woods, and henceforth while the green leaves grow bright as blossoms with the touch of frost, then brown and sere, and till long after they lie under the white 146 
shroud of winter, its wild denizens shall abide in constant fear and unrest.

So fares it with the wood-folk, these days of September, wherein the sportsman rejoiceth with exceeding gladness.

\section{7}




\section{XXXI}

A PLEA FOR THE UNPROTECTED

Why kill, for the mere sake of killing or the exhibition of one's skill, any wild thing that when alive harms no one and when killed is of no worth? The more happy wild life there is in the world, the pleasanter it is for all of us.

When one is duck-shooting on inland waters, sitting alert in the bow of the skiff with his gun ready for the expected gaudy wood duck, or plump mallard, or loud quacking dusky duck, or swiftwinged teal, to rise with a splashing flutter out of the wild rice, and there is a sudden beating of broad wings among the sedges with a startled guttural quack, and one's heart leaps to his throat and his gun to his shoulder, and then - only an awkward bittern climbs the September breeze with a slow incline, there is a vengeful temptation to let drive at the disappointing good-for-nothing. But . 148 
why not let the poor fellow go ? If you dropped him back into the marsh to rot unprofitably there, disdained even by the mink, unattainable to the scavenger skunk, what good would it do you? If he disappointed you, you disturbed him in his meditations, or in the pursuit of a poor but honest living. Perhaps a great heron too intent on his fishing or frogging, or dozing in the fancied seclusion of his reedy bower, springs up within short range and goes lagging away on his broad vans. He may be taken home to show, for he is worth showing even when killed. But if you wish your friends to see him at his best, bring them to him and let them see how well he befits these sedgy levels - a goodly sight, whether he makes his lazy flight above them or stands a motionless sentinel in the oozy shallows. The marshes would be desolate without him, or if one desires the charm of loneliness, his silent presence adds to it.

A kingfisher comes clattering along the channel. As he jerks his swift way over the sluggish water he may test your marksmanship, but as he hangs 
with rapid wing-beats over a school of minnows, as steadfast for a minute as a star forever, needing no skill to launch him to his final unrewarded plunge, do not kill him! In such waters he takes no fish that you would, and he enlivens the scene more than almost any other frequenter of it, never skulking and hiding, but with metallic, vociferous clatter heralding his coming. One never tires of watching his still mid-air poise, the same in calm or wind, and his unerring headlong plunge.

When one wanders along a willowy stream with his gun, cautiously approảching every lily-padded pool and shadowed bend likely to harbor wood duck or teal, and finds neither, and his ears begin to ache for the sound of his gun - if a green heron flaps off a branch before him he is sorely tempted to shoot the ungainly bird, but if the gun must be heard, let it speak to a stump or a tossed chip, either as difficult a target as he, and let the poor harmless little heron live. Uncouth as he is, he comes in well in the picture of such a watercourse, which has - done with the worry of turning mills, 150 
left far behind with their noise and bustle on foaming rapids among the hills, and crawls now in lazy ease through wide intervales, under elms and water maples and thickets of willows.

On the uplands, where the meadow lark starts out of the grass with a sharp, defiant "zeet!" and speeds away on his steady game-like flight, remember before you stop it, or try to, of how little account he is when brought to bag; and how when the weary days of winter had passed, his cheery voice welcomed the coming spring, a little later than the robin's, a little earlier than the flicker's cackle ; and what an enlivening dot of color his yellow breast made where he strutted in the dun, bare meadows.

In some States the woodpeckers are unprotected and are a mark for every gunner. Their galloping flight tempts the ambitious young shooter to try his skill, but they are among the best friends of the arboriculturist and the fruitgrower, for though some of them steal cherries and peck early apples, and one species sucks the sap of trees, they are 
the only birds that search out and kill the insidious, destructive borer.

In some States, too, the hare is unprotected by any law, and it is common custom to hunt it, even so late as April, for the mere sake of killing, apparently; or perhaps the charm of the hound's music, which makes the butchery of Adirondack deer so delightful a sport to some, adds a zest to the slaughter of these innocents - though, be it said, there is no comparison in the marksmanship required. Alive, the northern hare is one of the most harmless of animals ; dead, he is, in the opinion of most people, one of the most worthless; so worthless that hunters frequently leave the result of all their day's "sport" in the woods where they were killed. Yet the hare is legitimate game, and should be hunted as such, and only in proper seasons, and not be ruthlessly exterminated. A woodland stroll is the pleasanter if one sees a hare there in his brown summer suit, or white as the snow about him in his winter furs.

Where there are no statute laws for the protection of game and harmless 
creatures not so classed, an unwritten law of common sense, common decency, and common humanity should be powerful enough to protect all these. The fox is an outlaw; it is every one's legal right to kill him whenever and however he may, and yet wherever the fox is hunted with any semblance of fair play, whether in New England with gun and. hound, or elsewhere with horse and hound, the man who traps a fox, or kills one unseasonably, or destroys a vixen and her cubs, bears an evil reputation. A sentiment as popular and as potent ought to prevail to protect those that, though harmless, are as unshielded by legislative enactments as the fox, and much less guarded by natural laws and inborn cunning. 


\section{XXXII}

THE SKUNK

Always and everywhere in evil repute and bad odor, hunted, trapped, and killed, a pest and a fur-bearer, it is a wonder that the skunk is not exterminated, and that he is not even uncommon.

With an eye to the main chance, the fur-trapper spares him when fur is not prime, but when the letter " $R$ " has become well established in the months the cruel trap gapes for him at his outgoing and incoming, at the door of every discovered burrow, while all the year round the farmer, sportsman, and poultrygrower wage truceless war against him.

Notwithstanding this general outlawry, when you go forth of a winter morning, after a night of thaw or tempered chill, you see his authentic signature on the snow, the unmistakable diagonal row of four footprints each, or 
short-spaced alternate tracks, where he has sallied out for a change from the subterranean darkness of his burrow, or from his as rayless borrowed quarters beneath the barn, to the starlight or pale gloom of midnight winter landscape.

More often are you made aware of his continued survival by another sense than sight, when his far-reaching odor comes down the vernal breeze or waft of summer air, rankly overbearing all the fragrance of springing verdure, or perfume of flowers and new-mown hay, and you well know who has somewhere and somehow been forced to take most offensively the defensive.

It may be said of him that his actions speak louder than his words. Yet the voiceless creature sometimes makes known his presence by sound, and frightens the belated farm boy, whom he curiously follows with a mysterious, hollow beating of his feet upon the ground.

Patches of neatly inverted turf in a grub-infested pasture tell those who know his ways that the skunk has been doing the farmer good service here; and 
making amends for poultry stealing, and you are inclined to regard him with more favor. But when you come upon the empty shells of a raided partridge nest, your sportsman's wrath is enkindled against him for forestalling your gun. Yet who shall say that you had a better right to the partridges than he to the eggs?

If you are so favored, you can but admire the pretty sight of the mother with her cubs basking in a sunny nook or leading them afield in single file, a black and white procession.

If by another name the rose would smell as sweet, our old acquaintance is in far better odor for change of appellation from that so suggestive of his rank offenses. What beauty of fair faces would be spoiled with scorn by a hint of the vulgar name which in unadorned truth belongs to the handsome glossy black muff and boa that keep warm those dainty fingers and swan-like neck. Yet through the furrier's art and cunning they undergo a magic transformation into something to be worn with pride, and the every-day wear of the despised 
outlaw becomes the prized apparel of the fair lady.

If unto this humble night wanderer is vouchsafed a life beyond his brief earthly existence, imagine him in that unhunted, trapless paradise of uncounted eggs and callow nestlings, grinning a wide derisive smile as he beholds what fools we mortals be, so fooled by ourselves and one another. 


\section{XXXIII}

A CAMP-FIRE RUN WILD

Some wooden tent-pins inclosing a few square yards of ground half covered with a bed of evergreen twigs, matted but still fresh and odorous, a litter of paper and powder-smirched rags, empty cans and boxes, a few sticks of fire wood, a blackened, primitive wooden crane, with its half-charred supporting crotches, and a smouldering heap of ashes and dying brands, mark the place of a camp recently deserted.

Coming upon it by chance, one could not help a feeling of loneliness, something akin to that inspired by the cold hearthstone of an empty house, or the crumbling foundations of a dwelling long since fallen to ruin. What days and nights of healthful life have been spent here. What happy hours, never to return, have been passed here. What jokes have flashed about, what merry $15^{8}$ 
tales have been told, what joyous peals of laughter rung, where now all is silence. But no one is there to see it. A crow peers down from a treetop to discover what pickings he may glean, and a mink steals up from the landing, which bears the keelmarks of lately departed boats, both distrustful of the old silence which the place has so.suddenly resumed; and a company of jays flit silently about, wondering that there are no intruders to assail with their inexhaustible vocabulary.

A puff of wind rustles among the treetops, disturbing the balance of the crow, then plunges downward and sets aflight a scurry of dry leaves, and out of the gray ashes uncoils a thread of smoke and spins it off into the haze of leaves and shadows. The crow flaps in sudden alarm, the mink takes shelter in his coign of vantage among the driftwood, and the jays raise a multitudinous clamor of discordant outcry. The dry leaves alight as if by mischievous guidance of evil purpose upon the dormant embers, another puff of wind arouses a flame that first tastes them, then licks 
them with an eager tongue, then with the next eddying breath scatters its crumbs of sparks into the verge of the forest. These the rising breeze fans till it loads itself with a light burden of smoke, shifted now here, now there, as it is trailed along the forest floor, now climbing among the branches, then soaring skyward.

Little flames creep along the bodies of fallen trees and fluffy windrows of dry leaves, toying like panther kittens with their assured prey, and then, grown hungry with such dainty tasting, the flames upburst in a mad fury of devouring. They climb -swifter than panthers to treetops, falling back they gnaw savagely at tree roots, till the ancient lords of the forest reel and topple and fall before the gathering wind, and bear their destroyer still onward.

The leeward woods are thick with a blinding, stifling smoke, through which all the wild creatures of the forest flee in terror, whither they know not - by chance to safety, by equal chance perhaps to a terrible death in the surging deluge of fire. The billows of flame heave and I 60 
dash with a constant insatiate roar, tossing ever onward a red foam of sparks and casting a jetsam of lurid brands upon the ever-retreating strand that is but touched with the wash of enkindling, when it is overrun by the sea of fire.

The ice-cold springs grow hot in its fierce overwhelming wave, the purling rills hiss and boil and shrink before it, then vanish from their seared beds. All the living greenness of the forest is utterly consumed - great trees that have stood like towers, defying the centuries, with the ephemeral verdure of the woodland undergrowth; and to mark the place of all this recent majesty and beauty, there is but smouldering ruin and black and ashen waste. Little farms but lately uncovered to the sun out of the wilderness, cosy homesteads but newly builded, are swept away, and with them cherished hopes and perhaps precious lives. What irreparable devastation has been wrought by the campfire run wild!

Meanwhile the careless begetters of this havoc are making their leisurely way toward the outer world of civilizaI6r 


\section{A CAMP-FIRE RUN WILD}

tion, serenely noting that the woods are on fire, and complacently congratulating themselves that the disaster did not come to spoil their outing; never once thinking that by a slight exercise of that care which all men owe the world, this calamity, which a century cannot repair, might have been avoided. 


\section{XXXIV}

THE DEAD CAMP-FIRE

A HEAP of ashes, a few half-burned brands, a blackened pair of crotched sticks that mark the place of the once glowing heart of the camp, furnish food for the imagination to feed upon or give the memory an elusive taste of departed pleasures.

If you were one of those who saw its living flame and felt its warmth, the pleasant hours passed here come back with that touch of sadness which accompanies the memory of all departed pleasures and yet makes it not unwelcome. What was unpleasant, even what was almost unendurable, has nearly faded out of remembrance or is recalled with a laugh.

It was ten years ago, and the winds and fallen leaves of as many autumns have scattered and covered the gray heap. If it was only last year, you fancy 
that the smell of fire still lingers in the brands. How vividly return to you the anxious deliberation with which the site was chosen with a view to all attainable comfort and convenience, and the final satisfaction that followed the establishment of this short-lived home, short-lived but yet so much a home during its existence. Nothing contributed so much to make it one as the camp-fire. How intently you watched its first building and lighting, how labored for its maintenance with awkwardly-wielded axe, how you inhaled the odors of its cookery and essayed long-planned culinary experiments with extemporized implements, over its beds of coals, and how you felt the consequent exaltation of triumph or mortification of failure.

All these come back to you, and the relighting of the fire in the sleepy dawn, the strange mingling of white sunlight and yellow firelight when the sun shot its first level rays athwart the camp, the bustle of departure for the day's sport, the pleasant loneliness of camp-keeping with only the silent woods, the crackling fire, and your thoughts for company ; the 
incoming at nightfall and the rekindling of the fire, when the rosy bud of sleeping embers suddenly expanded into a great blossom of light whose petals quivered and faded and brightened among the encircling shadows of the woods. You laugh again at the jokes that ran around that merry circle and wonder again and again at the ingenuity with which small performances were magnified into great exploits, little haps into strange adventure, and with which bad shots and poor catches were excused.

At last came breaking camp, the desolation of dismantling and leave-taking. How many of you will ever meet again? How many of those merry voices are stilled forever, from how many of those happy faces has the light of life faded?

Who lighted this camp-fire? Years have passed since it illumined the nightly gloom of the woods, for moss and lichens are creeping over the charred back-log. A green film is spread over the ashes, and thrifty sprouts are springing up through them.

You know that the campers were tentdwellers, for there stand the rows of 165 
rotten tent pins inclosing a rusty heap of mould that once was a fragrant couch of evergreens inviting tired men to rest, or you know they spent their nights in a shanty, for there are the crumbling walls, the fallen-in roof of bark which never again will echo song or jest.

This pile of fish-bones attests that they were anglers, and skillful or lucky ones, for the pile is large. If you are an ichthyologist, you can learn by these vestiges of their sport whether they satisfied the desire of soul and stomach with the baser or the nobler fishes; perhaps a rotting pole, breaking with its own weight, may decide whether they fished with worm or fly ; but whether you relegate them to the class of scientific or unscientific anglers, you doubt not they enjoyed their sport as much in one way as in the other.

You know that they were riflemen, for there is the record of their shots in the healing bullet wounds on the trunk of a great beech. For a moment you may fancy that the woods still echo the laughter that greeted the shot that just raked 166 
the side of the tree; but it is only the cackle of a yellow-hammer.

There is nothing to tell you who they were, whence they came, or whither they went; but they were campers, lovers of the great outdoor world, and so akin to you, and you bid them hail and farewell without a meeting.

$$
\cdot 167
$$




\section{XXXV}

OCTOBER DAYS

Fields as green as when the summer birds caroled above them, woods more gorgeous with innumerable hues and tints of ripening leaves than a blooming parterre, are spread beneath the azure sky, whose deepest color is reflected with intenser blue in lake and stream. In them against this color are set the scarlet and gold of every tree upon their brinks, the painted hills, the clear-cut mountain peaks, all downward pointing to the depths of this nether sky.

Overhead, thistledown and the silken balloon of the milkweed float on their zephyr - wafted course, silver motes against the blue; and above them are the black cohorts of crows in their straggling retreat to softer climes. Now the dark column moves steadily onward, now veers in confusion from some suspected or discovered danger, or pauses to assail I 68 
with a harsh clangor some sworn enemy of the sable brotherhood. Their gayclad smaller cousins, the jays, are for the most part silently industrious among the gold and bronze of the beeches, flitting to and fro with flashes of blue as they gather mast, but now and then finding time to scold an intruder with an endless variety of discordant outcry.

How sharp the dark shadows are cut against the sunlit fields, and in their gloom how brightly shine the first fallen leaves and the starry bloom of the asters. In cloudy days and even when rain is falling the depths of the woods are not dark, for the bright foliage seems to give forth light and casts no shadows beneath the lowering sky.

The scarlet maples burn, the golden leaves of poplar and birch shine through the misty veil, and the deep purple of the ash glows as if it held a smouldering fire that the first breeze might fan into a flame, and through all this luminous leafage one may trace branch and twig as a wick in a candle flame. Only the evergreens are dark as when they bear their steadfast green in the desI69 
olation of winter, and only they brood shadows.

In such weather the woodland air is laden with the light burden of odor, the faintly pungent aroma of the ripened leaves, more subtle than the scent of pine or fir, yet as apparent to the nostrils, as delightful and more rare, for in the round of the year its days are few, while in summer sunshine and winter wind, in springtime shower and autumnal frost, pine, spruce, balsam, hemlock, and cedar distill their perfume and lavish it on the breeze or gale of every season.

Out of the marshes, now changing . their universal green to brown and bronze and gold, floats a finer odor than their common reek of ooze and sodden weeds - a spicy tang of frost-ripened flags and the fainter breath of the landward border of ferns; and with these also is mingled the subtle pungency of the woodlands, where the pepperidge is burning out in a blaze of scarlet, and the yellow flame of the poplars flickers in the lightest breeze.

The air is of a temper neither too hot nor too cold, and in what is now rather 
the good gay wood than green wood, there are no longer pestering insects to worry the flesh and trouble the spirit. The flies bask in half torpid indolence, the tormenting whine of the mosquito is heard no more. Of insect life one hears little but the mellow drone of the bumblebee, the noontide chirp of the cricket, and the husky rustle of the dragonfly's gauzy wing.

Unwise are the tent-dwellers who have folded their canvas and departed to the shelter of more stable roof-trees, for these are days that should be made the most of, days that have brought the perfected ripeness of the year and display it in the fullness of its glory. 


\section{XXXVI}

\section{A COMMON EXPERIENCE}

THE keenest of the sportsman's disappointments is not a blank day, nor a series of misses, unaccountable or too well accountable to a blundering hand or unsteady nerves, nor adverse weather, nor gun or tackle broken in the midst of sport, nor perversity of dogs, nor uncongeniality of comradeship, nor yet even the sudden cold or the spell of rheumatism that prevents his taking the field on the allotted morning.

All these may be but for a day. Tomorrow may bring game again to haunts now untenanted, restore cunning to the awkward hand, steady the nerves, mend the broken implement, make the dogs obedient and bring pleasanter comrades or the comfortable lonesomeness of one's own companionship, and to-morrow or next day or next week the cold and I 72 
rheumatic twinges may have passed into the realm of bygone ills.

For a year, perhaps for many years, he has yearned for a sight of some beloved haunt, endeared to him by old and cherished associations. He fancies that once more among the scenes of his youthful exploits there will return to him something of the boyish ardor, exuberance of spirit and perfect freedom from care that made the enjoyment of those happy hours so complete. $\mathrm{He}$ imagines that a draught from the old spring that bubbles up in the shadow of the beeches or from the moss-brimmed basin of the trout brook will rejuvenate him, at least for the moment while its coolness lingers on his palate, as if he quaffed Ponce de Leon's undiscovered fountain. He doubts not that in the breath of the old woods he shall once more catch that faint, indescribable, but unforgotten aroma, that subtle savor of wildness, that has so long eluded him, sometimes tantalizing his nostrils with a touch, but never quite inhaled since its pungent elixir made the young blood tingle in his veins. 
He has almost come to his own again, his long-lost possession in the sunny realm of youth. It lies just beyond the hill before him, from whose crest he shall see the nut-tree where he shot his first squirrel, the southing slope where the beeches hide the spring, where he astonished himself with the glory of killing his first grouse, and he shall see the glint of the brook flashing down the evergreen dell and creeping among the alder copses.

He does not expect to find so many squirrels or grouse or trout now as thirty years ago, when a double gun was a wonder, and its possession the unrealized dream of himself and his comrades, and mone of them had ever seen jointed rod or artificial fly, and dynamite was uninvented. Yet all the game and fish cannot have been driven from nor exterminated in haunts so congenial and fostering as these, by the modern horde of gunners and anglers and by the latter-day devices of destruction, and he doubts not that he shall find enough to satisfy the tempered ardor of the graybeard. 
Indeed, it is for something better than mere shooting or fishing that he has come so far. One squirrel, flicking the leaves with his downfall, one grouse plunging to earth midway in his thunderous flight, one trout caught as he can catch him, now, will appease his moderate craving for sport, and best and most desired of all, make him, for the nonce,'a boy again. He anticipates with quicker heartbeat the thrill of surprised delight that choked him with its fullness when he achieved his first triumph.

At last the hilltop is gained, but what unfamiliar scene is this which has taken the place of that so cherished in his memory and so longed for? Can that naked hillside slanting toward him from the further rim of the valley, forlorn in the desolation of recent clearing, be the wooded slope of the other day? Can the poor, unpicturesque thread of water that crawls in feeble attenuation between its shorn, unsightly banks be the wild, free brook whose voice was a continual song, every rod of whose amber and silver course was a picture? Even its fringes of willow and alders, useful for their shade 
and cover when alive, but cut down worthless even for fuel, have been swept from its margin by the ruthless besom of destruction, as if everything that could beautify the landscape must be blotted out to fulfill the mission of the spoiler.

Near it, and sucking in frequent draughts from the faint stream, is a thirsty and hungry little sawmill, the most obtrusive and most ignoble feature of the landscape, whose beauty its remorseless fangs have gnawed away. Every foot of the brook below it is foul with its castings, and the fragments of its continual greedy feasting are thickly strewn far and near. Yet it calls to the impoverished hills for more victims; its shriek arouses discordant echoes where once resounded the music of the brook, the song of birds, the grouse's drum call, and the mellow note of the hound.

Though sick at heart with the doleful scene, the returned exile descends to his harried domain hoping that he may yet find some vestige of its former wealth, but only more disappointments reward his quest. Not a trout flashes through the shrunken pools. The once limpid 


\section{A COMMON EXPERIENCE}

spring is a quagmire among rotting stumps. The rough nakedness of the hillside is clad only with thistles and fireweed, with here and there a patch of blanched dead leaves, dross of the old gold of the beech's ancient autumnal glory.

Of all he hoped for nothing is realized, and he finds only woful change, irreparable loss. His heart heavy with sorrow and bursting with impotent wrath against the ruthless spoiler, he turns his back forever on the desolated scene of his boyhood's sports.

Alas! That one should ever attempt to retouch the time-faded but beautiful pictures that the memory holds. 


\section{XXXVII}

THE RED SQUIRREL

A HAwK, flashing the old gold of his pinions in the face of the sun, flings down a shrill, husky cry of intense scorn; a jay scolds like a shrew; from his safe isolation in the midwater, a loon taunts you and the awakening winds with his wild laughter; there is a jeer in the chuckling diminuendo of the woodchuck's whistle, a taunt in the fox's gasping bark as he scurries unseen behind the veil of night; and a scoff on hunters and hounds and cornfield owners is flung out through the gloaming in the raccoon's quavering cry. But of all the wild world's inhabitants, feathered or furred, none outdo the saucy red squirrel in taunts, gibes, and mockery of their common enemy.

$\mathrm{He}$ is inspired with derision that is expressed in every tone and gesture. His agile form is vibrant with it when 178 
he flattens himself against a tree-trunk, toes and tail quivering with intensity of ridicule as fully expressed in every motion as in his nasal snicker and throaty chuckle or in the chattering jeer that he pours down when he has attained a midway or topmost bough and cocks his tail with a saucy curve above his arched back.

When he persistently retires within his wooden tower, he still peers out saucily from his lofty portal, and if he disappears you may yet hear the smothered chuckle wherewith he continues to tickle his ribs. When in a less scornful mood, he is at least supremely indifferent, deigning to regard you with but the corner of an eye, while he rasps a nut or chips a cone.

Ordinarily you must be philosophical or godly to suffer gibes with equanimity, but you need be neither to endure the scoffs of this buffoon of the woods and waysides. They only amuse you as they do him, and you could forgive these tricks tenfold multiplied if he had no worse, and love him if he were but half as good as he is beautiful. 
He exasperates when he cuts off your half-grown apples and pears in sheer wantonness, injuring you and profiting himself only in the pleasure of seeing and hearing them fall. But you are heated with a hotter wrath when he reveals his chief wickedness, and you catch sight of him stealthily skulking along the leafy by-paths of the branches, silently intent on evil deeds and plotting the murder of callow innocents. Quite noiseless now, himself, his whereabouts are only indicated by the distressful outcry of the persecuted and sympathizing birds and the fluttering swoops of their futile attacks upon the marauder. Then when you see him gliding away, swift and silent as a shadow, bearing a halfnaked fledgeling in his jaws, if this is the first revelation of such wickedness, you are as painfully surprised as if you had discovered a little child in some wanton act of cruelty.

It seems quite out of all fitness of nature that this merry fellow should turn murderer, that this dainty connoisseur of choice nuts and tender buds, and earliest discoverer and taster of the 180 
maple's sweetness, should become so grossly carnivorous and savagely bloodthirsty. But anon he will cajole you with pretty ways into forgetfulness and forgiveness of his crimes. You find yourself offering, in extenuation of his sins, confession of your own offenses. Have not you, too, wrought havoc among harmless broods and brought sorrow to feathered mothers and woodland homes? Is he worse than you, or are you better than he? Against his sins you set his beauty and tricksy manners, and for them would not banish him out of the world nor miss the incomparable touch of wild life that his presence gives it.

I8I 


\section{XXXVIII}

THE RUFFED GROUSE

THE woods in the older parts of our country possess scarcely a trait of the primeval forest. The oldest trees have a comparatively youthful appearance, and are pygmies in girth beside the decaying stumps of their giant ancestors. They are not so shagged with moss nor so scaled with lichens. The forest floor has lost its ancient carpet of ankle-deep moss and the intricate maze of fallen trees in every stage of decay, and looks clean-swept and bare. The tangle of undergrowth is gone, many of the species which composed it having quite disappeared, as have many of the animals that flourished in the perennial shade of the old woods.

If in their season one sees and hears more birds among their lower interlaced branches, he is not likely to catch sight or sound of many of the denizens of the I 82 
old wilderness. No startled deer bounds away before him, nor bear shuffles awkwardly from his feast of mast at one's approach, nor does one's flesh creep at the howl of the gathering wolves or the panther's scream or the rustle of his stealthy footsteps.

But as you saunter on your devious way you may hear a rustle of quick feet in the dry leaves and a sharp, insistent cry, a succession of short, high-pitched clucks running into and again out of a querulous "ker-r-r-r," all expressing warning as much as alarm. Your ears guide your eyes to the exact point from which the sounds apparently come, but if these are not keen and well trained they fail to detach any animate form from the inanimate dun and gray of dead leaves and underbrush.

With startling suddenness out of the monotony of lifeless color in an eddying flurry of dead leaves, fanned to erratic flight by his wing-beats, the ruffed grouse bursts into view, in full flight with the first strokes of his thundering pinions, and you have a brief vision of untamed nature as it was in the old days. 
On either side of the vanishing brown nebula the ancient mossed and lichened trunks rear themselves again, above it their lofty ramage veils the sky, beneath it lie the deep, noiseless cushion of moss, the shrubs and plants that the old wood rangers knew and the moose browsed on, and the tangled trunks of fallen trees. You almost fancy that you hear the longago silenced voices of the woods, so vividly does this wild spirit for an instant conjure up a vision of the old wild world whereof he is a survival.

Acquaintance with civilized man has not tamed him, but has made him the wilder. He deigns to feed upon appletree buds and buckwheat and woodside clover, not as a gift, but a begrudged compensation for what you have taken from him, and gives you therefor not even the thanks of familiarity; and notwithstanding his acquaintance with generations of your race he will not suffer you to come so near to him as he would your grandfather.

If, when the leaves are falling, you find him in your barnyard, garden, or out-house, or on the porch, do not think 184 
he has any intention of associating with you or your plebeian poultry. You can only wonder where he found refuge from the painted shower when all his world was wooded. If he invites your attendance at his drum solo, it is only to fool you with the sight of an empty stage, for you must be as stealthy and keeneyed as a lynx to see his proud display of distended ruff and wide spread of barred tail and accelerated beat of wings that mimic thunder, or see even the leafy curtain of his stage flutter in the wind of his swift exit.

How the definite recognition of his motionless form evades you, so perfectly are his colors merged into those of his environment, whether it be in the flush greenness of summer, the painted hues of autumn or its later faded dun and gray, or in the whiteness of winter. Among one or the other he is but a clot of dead leaves, a knot upon a branch, the gray stump of a sapling protruding from the snow, or, covered deep in the unmarked whiteness, he bursts from it like a mine exploded at your feet, leaving you agape till he has vanished from 185 
your sight and your ears have caught the last flick of his wings against the dry branches.

In May, his mate sits on her nest, indistinguishable among the brown leaves and gray branches about her. Later, when surprised with her brood, how conspicuous she makes herself, fluttering and staggering along the ground, while her callow chicks, old in cunning though so lately their eyes first beheld the world, scatter in every direction like a shattered globule of quicksilver and magically disappear where there is no apparent hiding-place. Did they con the first lesson of safety in the dark chamber of the egg, or absorb it with the warmth of the brooding breast that gave them life?

Listen, and out of the silence which follows the noisy dispersion of the family hear the low sibilant voice of the mother calling her children to her or cautioning them to continued hiding. Perhaps you may see her, alertly skulking among the underbrush, still uttering that tender, persuasive cry, so faint that the chirp of a cricket might overbear it. Scatter her brood when the members are half grown I86 
and almost as strong of wing as herself, and you presently hear her softly calling them and assuring them of her continued care.

Among many things that mark the changing season, is the dispersion of this wildwood family. Each member is now shifting for itself in matters of seeking food, safety, pleasure, and comfort. You will come upon one in the ferny undergrowth of the lowland woods where he is consorting with woodcock, frighten another from his feast on the fenceside elderberries, scare one in the thick shadows of the evergreens, another on the sparsely wooded steep of a rocky hillside, and later hear the drum-beat of a young cock that the soft Indian summer has fooled into springtime love-making, and each has the alertness that complete self-dependence has enforced.

Still, you may come upon them gathered in social groups, yet each going his own way when flushed. Upon rare occasions you may surprise a grand convention of all the grouse of the region congregated on the sunny lee of a hillside. It is a sight and sound to remem187 
ber long, though for the moment you forget the gun in your hands, when by ones, twos, and dozens the dusky forms burst away up wind, down wind, across wind, signalling their departure with volleys of intermittent and continuous thunder. Not many times in your life will you see this, yet, if but once, you will be thankful that you have not outlived all the old world's wildness. 


\section{XXXIX}

\section{TWO SHOTS}

A BOy of fourteen, alert, but too ful! of life to move slowly and cautiously, is walking along an old road in the woods, a road that winds here and there with meanderings that now seem vagrant and purposeless but once led to the various piles of cordwood and logs for whose harvesting it was hewn. Goodly trees have since grown up from saplings that the judicious axe then scorned. Beeches, whose flat branches are shelves of old gold ; poplars, turned to towers of brighter metal by the same alchemy of autumn ; and hemlocks, pyramids of unchanging green, shadow the leaf-strewn forest floor and its inconspicuous dotting of gray and russet stumps. How happy the boy is in the freedom of the woods; proud to carry his first own gun, as he treads gingerly but somewhat noisily over the fallen leaves and dry twigs, 
scanning with quick glances the thickets, imagining himself the last Mohican on the warpath, or Leather-Stocking scouting in the primeval wilderness.

Under his breath he tells the confiding chickadees and woodpeckers what undreamed-of danger they would be in from such a brave, were he not in pursuit of nobler game. Then he hears a sudden rustle of the dry leaves, the quit! quit! of a partridge, catches a glimpse of a rapidly running brown object, which on the instant is launched into a flashing thunderous flight. Impelled by the instinct of the born sportsman, he throws the gun to his shoulder, and scarcely with aim, but in the direction of the sound, pulls trigger and fires.

On the instant he is ashamed of his impulsive haste, which fooled him into wasting a precious charge on the inanimate evergreen twigs and sere leaves that come dropping and floating down to his shot, and is thankful that he is " the only witness of his own foolishness.

But what is that? Above the patter and rustle of falling twigs and leaves comes a dull thud, followed by the rapid 
beat of wings upon the leaf-strewn earth. With heart beating as fast he runs toward the sound, afraid to believe his senses, when he sees a noble grouse fluttering out feebly his last gasp. He cannot be sure that it is not all a dream that may vanish in a breath, till he has the bird safe in his hand, and then he is faint with joy. Was there ever such a shot? Would that all the world were here to see, for who can believe it just for the telling? There never will be another such a bird, nor such a shot, for him. $\mathrm{He}$ fires a dozen ineffectual ones at fair marks that day, but the glory of that one shot would atone for twice as many misses, and he need not tell of them, only of this, whereof he bears actual proof, though he himself can hardly accept it, till again and again he tests it by admiring look and touch.

Years after the killing of grouse on the wing has become a matter-of-course occurrence in his days of upland shooting, the memory of this stands clearest and best. Sixty years later the old wood road winds through the same scene, by some marvel of kindliness or 
oversight, untouched by the devastating axe, unchanged but by the forest growth of half a century and its seemly and decorous decay. A thicker screen of undergrowth borders the more faintly traced way. The golden-brown shelves of the beech branches sweep more broadly above it, the spires of the evergreens are nearer the sky, and the yellow towers of the poplars are builded higher, but they are the same trees and beneath them may yet be seen the gray stumps and trunks mouldered to russet lines, of their ancient brethren who fell when these were saplings.

The gray-bearded man who comes along the old wood road wonders at the little change so many years have made in the scene of the grand achievements of his youth, and in his mind he runs over the long calendar to assure himself that so many autumns have glowed and faded since that happy day. How can he have grown old, his ear dull to the voices of the woods, his sight dim with the slowly but surely falling veil of coming blindness, so that even now the road winds into a misty haze just before I92 
him, yet these trees be young and lusty?

As they and the unfaded page of memory record the years, it was but a little while ago that his heart was almost bursting with pride of that first triumph. Would that he might once more feel that delicious pang of joy.

Hark! There is the quit! quit! of a grouse, and there another and another, and the patter and rustle of their retreating footsteps, presently launching into sudden flight, vaguely seen in swift bolts of gray, hurtling among gray tree trunks and variegated foliage. True to the old instinct his gun leaps to his shoulder, and he fires again and again at the swift target. But the quick eye no longer guides the aim, the timely finger no longer pulls the trigger, and the useless pellets waste themselves on the leaves and twigs.

The woods are full of grouse, as if all the birds of the region had congregated here to mock his failing sight and skill. On every side they burst away from him like rockets, and his quick but futile charges in rapid succession are poured 
in their direction, yet not a bird falls, nor even a feather wavers down through the still October air. His dim eyes refuse to mark down the birds that alight nearest ; he can only vaguely follow their flight by the whirring rush of wings and the click of intercepting branches.

He is not ashamed of his loss of skill, only grieved to know that his shooting days are over, yet he is glad there is no one near to see his failure. He makes renunciation of all title to the name of a crack shot, too well knowing that this is no brief lapse of skill, but the final, inevitable falling off of the quick eye and sure hand. Slowly and sadly he makes his way to where the shaded path merges into the sunny clearing. There, from the cover of the last bush, a laggard bird springs as if thrown from a catapult, describing in his flight an arc of a great circle, and clearly defined against the steel-blue sky.

Again the gun springs instinctively to the shoulder, the instantaneous aim is taken well ahead on the line of flight, the trigger pressed in the nick of time, 
the charge explodes, and out of a cloud of feathers drifting and whirling in the eddies of his own wing-beats, the noble bird sweeps downward in the continuation of the course that ends with a dull thud on the pasture sward.

The old sportsman lifts his cleankilled bird without a thrill of exultation - he is only devoutly thankful for the happy circumstance which made successful the last shot he will ever fire, and that not as a miss he may remember it. Henceforth untouched by him his gun shall hang upon the wall, its last use linked with the pleasant memory of his last shot. 


\section{XL}

NOVEMBER DAYS

IN a midsummer sleep one dreams of winter, its cold, its silence and desolation all surrounding him; then awakes, glad to find himself in the reality of the light and warmth of summer.

Were we dreaming yesterday of woods more gorgeous in their leafage than a flower garden in the flush of profusest bloom, so bright with innumerable tints that autumnal blossoms paled beside them as stars at sunrise? Were we dreaming of air soft as in springtime, of the gentle babble of brooks, the carol of bluebirds, the lazy chirp of crickets, and have we suddenly awakened to be confronted by the desolation of naked forests, the more forlorn for the few tattered remnants of gay apparel that flutter in the bleak wind? To hear but the sullen roar of the chill blast and the clash of stripped boughs, the fitful scurry of wind196 
swept leaves and the raving of swollen streams, swelling and falling as in changing stress of passion, and the heavy leaden patter of rain on roof and sodden leaves and earth?

Verily, the swift transition is like a pleasant dream with an unhappy awakening. Yet not all November days are dreary. Now the sun shines warm from the steel-blue sky, its eager rays devour the rime close on the heels of the retreating shadows, and the north wind sleeps. The voice of the brimming stream falls to an even, softer cadence, like the murmur of pine forests swept by the light touch of a steady breeze.

Then the wind breathes softly from the south, and there drifts with it from warmer realms, or arises at its touch from the earth about us, or falls from the atmosphere of heaven itself, not smoke, nor haze, but something more ethereal than these: a visible air, balmy with odors of ripeness as the breath of June with perfume of flowers. It pervades earth and sky, which melt together in it, till the bounds of neither are discernible, and blends all objects in the 
landscape beyond the near foreground, till nothing is distinct but some golden gleam of sunlit water, bright as the orb that shines upon it. Flocks of migrating geese linger on the stubble fields, and some laggard crows flap lazily athwart the sky or perch contentedly upon the naked treetops as if they cared to seek no clime more genial. The brief heavenly beauteousness of Indian summer has fallen upon the earth, a few tranquil days of ethereal mildness dropped into the sullen or turbulent border of winter.

In November days; as in all others, the woods are beautiful to the lover of nature and to the sportsman who in their love finds the finer flavor of his pastime. Every marking of the gray trunks, each moss-patch and scale of lichen on them, is shown more distinctly now in the intercepted light, and the delicate tracery of the bare branches and their netted shadows on the rumpled carpet of the forest floor, have a beauty as distinctive as the fullness of green or frost-tinted leafage and its silhouette of shade. 
No blossom is left in woods or fields, save where in the one the witch-hazel unfolds its unseasonable flowers yellow beneath cold skies, or a pink blossom of herb-robert holds out with modest bravery in a sheltered cranny of the rocks; and where in the other, the ghostly bloom of everlasting rustles above the leafless stalks in the wind-swept pastures. There are brighter flashes of color in the sombre woods where the red winterberries shine on their leafless stems and the orange and scarlet clusters of the twining bitter-sweet light up the gray trellis of the vagrant climber.

No sense of loss or sadness oppresses the soul of the ardent sportsman as he ranges the unroofed aisles alert for the wary grouse, the skulking woodcock, full-grown and strong of wing and keeneyed for every enemy, or the hare flashing his half-donned winter coat among the gray underbrush as he bounds away before the merry chiding of the beagles. The brown monotony of the marshes is pleasant to him as green fields, while the wild duck tarries in the dark pools and the snipe probes the unfrozen patches of 
ooze. To him all seasons are kind, all days pleasant, wherein he may pursue his sport, though the rain pelt him, chill winds assail him, or the summer sun shower upon him its most fervent rays, and in these changeful days of November he finds his full measure of content. 200 


\section{XLI}

\section{THE MUSKRAT}

A LitTle turning of nature from her own courses banishes the beaver from his primal haunts, but his less renowned and lesser cousin, the muskrat, philosophically accommodates himself to the changed conditions of their common foster mother and still clings fondly to her altered breast.

The ancient forests may be swept away and their successors disappear, till there is scarcely left him a watersoaked $\log$ to use as an intermediate port in his coastwise voyages; continual shadow may give place to diurnal sunshine, woodland to meadow and pasture, the plough tear the roof of his underground home, and cattle graze where once only the cloven hoofs of the deer and the moose trod the virgin mould, yet he holds his old place.

In the springtides of present years as in those of centuries past his whining 
call echoes along the changed shores, his wake seams with silver the dark garment of the water, and his comically grim visage confronts you now as it did the Waubanakee bowmen in the old days when the otter and the beaver were his familiars.

Unlike the beaver's slowly maturing crops, his food supply is constantly provided in the annual growth of the marshes. Here in banks contiguous to endless store of succulent sedge and lily roots and shell-cased tidbits of mussels, he tunnels his stable water-portaled home, and out there, by the channel's edge, builds his sedge-thatched hut before the earliest frost falls upon the marshes. In its height, some find prophecy of high or low water, and in the thickness of its walls the forecast of a mild or severe winter, but the prophet himself is sometimes flooded out of his house, sometimes starved and frozen in it.

In the still, sunny days between the nights of its unseen building, the blue spikes of the pickerel-weed and the white trinities of the arrow-head yet 
bloom beside it. Then in the golden and scarlet brightness of autumn the departing wood drake rests on the roof to preen his plumage, and later the dusky duck swims on its watery lawn. Above it the wild geese harrow the low, cold arch of the sky, the last fleet of sere leaves drifts past it in the bleak wind, and then ice and snow draw the veil of the long winter twilight over the muskrat's homes and haunts.

These may be gloomy days he spends groping in the dark chambers of his hut and burrow, or gathering food in the dimly lighted icy water, with never a sight of the upper world nor ever a sunbeam to warm him.

But there are more woful days when the sun and the sky are again opened to him, and he breathes the warm air of spring, hears the blackbirds sing and the bittern boom. For, amid all the gladness of nature's reawakened life, danger lurks in all his paths; the cruel, hungry trap gapes for him on every jutting log, on every feeding-bed, even in the doorway of his burrow and by the side of his house. 
The trapper's skiff invades all his pleasant waters ; on every hand he hears the splash of its paddles, the clank of its setting pole, and he can scarcely show his head above water but a deadly shower of lead bursts upon it. He hears the simulated call of his beloved, and voyaging hot-hearted to the cheating tryst meets only death.

At last comes the summer truce and happy days of peace in the tangled jungle of the marsh, with the wild duck and bittern nesting beside his watery path, the marsh wren weaving her rushy bower above it.

So the days of his life go on, and the days of his race continue in the land of his unnumbered generations. Long may he endure to enliven the drear tameness of civilization with a memory of the world's old wildness. 


\section{XLII}

\section{NOVEMBER VOICES}

With flowers and leaves, the bird songs have faded out, and the hum and chirp of insect life, the low and bleat of herds and flocks afield, and the busy sounds of husbandry have grown infrequent. There are lapses of such silence that the ear aches for some audible signal of life ; and then to appease it there comes with the rising breeze the solemn murmur of the pines like the song of the sea on distant shores, the sibilant whisper of the dead herbage, the clatter of dry pods, and the fitful stir of fallen leaves, like a scurry of ghostly feet fleeing in affright at the sound of their own passage.

The breeze puffs itself into a fury of wind, and the writhing branches shriek and moan and clash as if the lances of phantom armies were crossed in wild mêlée. 
The woods are full of unlipped voices speaking one with another in pleading, in anger, in soft tones of endearment; and one hears.his name called so distinctly that he answers and calls again, but no answer is vouchsafed him, only moans and shrieks and mocking laughter, till one has enough of wild voices and longs for a relapse of silence.

More softly it is broken when through the still air comes the cheery note of the chickadee and the little trumpet of his comrade the nuthatch and far away the muffled beat of the grouse's drum, or from a distance the mellow baying of a hound and its answering echoes, swelling and dying on hilltop or glen, or mingling in melodious confusion.

From skyward comes the clangor of clarions, wild and musical, proclaiming the march of gray cohorts of geese advancing southward through the hills and dales of cloudland. There come, too, the quick whistling beat of wild ducks' pinions, the cry of a belated plover, and the creaking voice of a snipe. Then the 206 
bawling of a ploughman in a far-off field - and farther away the rumble and shriek of a railroad train - brings the listening ear to earth again and its plodding busy life. 


\section{XLIII}

\section{THANKSGIVING}

DoubTLEss many a sportsman has bethought him that his Thanksgiving turkey will have a finer flavor if the feast is prefaced by 'a few hours in the woods, with dog and gun. Meaner fare than this day of bounty furnishes forth is made delicious by such an appetizer, and the Thanksgiving feast will be none the worse for it.

What can be sweeter than the wholesome fragrance of the fallen leaves? What more invigorating than the breath of the two seasons that we catch: here in the northward shade of a wooded hill the nipping air of winter, there where the southern slope meets the sun the genial warmth of an October day. Here one's footsteps crunch sharply the frozen herbage and the ice-bearded border of a spring's overflow ; there splash in thawed pools and rustle softly among the dead leaves. 
The flowers are gone, but they were not brighter than the winter berries and bittersweet that glow around one. The deciduous leaves are fallen and withered, but they were not more beautiful than the delicate tracery of their forsaken branches, and the steadfast foliage of the evergreens was never brighter. The song-birds are singing in southern woods, but chickadee, nuthatch, and woodpecker are chatty and companionable and keep the woods in heart with a stir of life.

Then from overhead or underfoot a ruffed grouse booms away into the gray haze of branches, and one hears the whirr and crash of his headlong flight long after he is lost to sight, perchance long after the echo of a futile shot has died away. Far off one hears the intermittent discharge of rifles where the shooters are burning powder for their Thanksgiving turkey, and faintly from far away comes the melancholy music of a hound. Then nearer and clearer, then a rustle of velvet-clad feet, and lo, reynard himself, the wildest spirit of the woods, materializes out of the russet in- 
distinctness and flashes past, with every sense alert. Then the hound goes by, and footstep, voice, and echo sink into silence. For silence it is, though the silver tinkle of the brook is in it, and the stir of the last leaf shivering forsaken on its bough.

In such quietude one may hold heartfelt thanksgiving, feasting full upon a crust and a draught from the icy rivulet, and leave rich viands and costly wines for the thankless surfeiting of poorer men. 


\section{XLIV}

\section{DECEMBER DAYS}

FEwer and more chill have become the hours of sunlight, and longer stretch the noontide shadows of the desolate trees athwart the tawny fields and the dead leaves that mat the floor of the woods.

The brook braids its shrunken strands of brown water with a hushed murmur over a bed of sodden leaves bétween borders of spiny ice crystals, or in the pools swirl in slow circles the imprisoned fleets of bubbles beneath a steadfast roof of glass. Dark and sullen the river sulks its cheerless way, enlivened but by the sheldrake that still courses his prey in the icy water, and the mink that like a fleet black shadow steals along the silent banks. Gaudy wood duck and swift-winged teal have long since departed and left stream and shore to these marauders and to the trapper, who now gathers here his latest harvest. 
The marshes are silent and make no sign of life, though beneath the domes of many a sedge-built roof the unseen muskrats are astir, and under the icy cover of the channels fare to and fro on their affairs of life, undisturbed by any turmoil of the upper world.

When the winds are asleep the lake bears on its placid breast the moveless images of its quiet shores, deserted now by the latest pleasure seekers among whose tenantless camps the wild woodfolk wander as fearlessly as if the foot of man had never trodden here. From the still midwaters far away a loon halloos to the winds to come forth from their caves, and yells out his mad laughter in anticipation of the coming storm. A herald breeze blackens the water with its advancing steps, and with a roar of its trumpets the angry wind sweeps down, driving the white-crested ranks of waves to assault the shores. Far up the long incline of pebbly beaches they rush, and leaping up the walls of rock hang fetters of ice upon the writhing trees. Out of the seething waters arise lofty columns of vapor, which like a host of 
gigantic phantoms stalk, silent and majestic, above the turmoil, till they fall in wind-tossed showers of frost flakes.

There are days when almost complete silence possesses the woods, yet listening intently one may hear the continual movement of myriads of snow fleas pattering on the fallen leaves like the soft purr of such showers as one might imagine would fall in Lilliput.

With footfall so light that he is seen close at hand sooner than heard, a hare limps past; too early clad in his white fur that shall make him inconspicuous amid the winter snow, his coming shines from afar through the gray underbrush and on the tawny leaves. Unseen amid his dun and gray environment, the ruffed grouse skulks unheard, till he bursts away in thunderous flight. Overhead, invisible in the lofty thicket of a hemlock's foliage, a squirrel drops a slow patter of cone chips, while undisturbed a nuthatch winds his spiral way down the smooth trunk. Faint and far away, yet clear, resound the axe strokes of a chopper, and at intervals the muffled roar of a tree's downfall. 
Silent and moveless cascades of ice veil the rocky steeps where in more genial days tiny rivulets dripped down the ledges and mingled their musical tinkle with the songs of birds and the flutter of green leaves.

Winter berries and bittersweet still give here and there a fleck of bright color to the universal gray and dun of the trees, and the carpet of cast-off leaves and the dull hue of the evergreens but scarcely relieve the sombreness of the woodland landscape.

Spanning forest and field with a low flat arch of even gray, hangs a sky as cold as the landscape it domes and whose mountain borders lie hidden in its hazy foundations. Through this canopy of suspended snow the low noontide sun shows but a blotch of yellowish gray, rayless and giving forth no warmth, and, as it slants toward its brief decline, grows yet dimmer till it is quite blotted out in the gloom of the half-spent afternoon.

The expectant hush that broods over the forlorn and naked earth is broken only by the twitter of a flock of snow buntings which, like a straight - blown 
flurry of flakes, drift across the fields, and, sounding solemnly from the depths of the woods, the hollow hoot of a great owl. Then the first flakes come wavering down, then blurring all the landscape into vague unreality they fall faster, with a soft purr on frozen grass and leaves till it becomes unheard on the thickening noiseless mantle of snow. Deeper and deeper the snow infolds the earth, covering all its unsightliness of death and desolation.

Now white-furred hare and whitefeathered bunting are at one with the white-clad world wherein they move, and we, so lately accustomed to the greenness of summer and the gorgeousness of autumn, wondering at the ease wherewith we accept this marvel of transformation, welcome these white December days and in them still find content. 


\section{XLV}

\section{WINTER VOICES}

Out of her sleep nature yet gives forth voices betokening that life abides beneath the semblance of death, that her warm heart still beats under the white shroud that infolds her rigid breast.

A smothered tinkle as of muffled bells comes up from the streams through their double roofing of snow and ice, and the frozen pulse of the trees complains of its thralldom with a resonant twang as of a strained cord snapped asunder.

Beneath their frozen plains, the lakes bewail their imprisonment with hollow moans awakening a wild and mournful chorus of echoes from sleeping shores that answer now no caress of ripples nor angry stroke of waves nor dip and splash of oar and paddle.

The breeze stirs leafless trees and shaggy evergreens to a murmur that is sweet, if sadder than they gave it in the 
leafy days of summer, when it bore the perfume of flowers and the odor of green fields, and one may imagine the spirit of springtime and summer lingers among the naked boughs, voicing memory and hope.

Amid all the desolation of their woodland haunts the squirrels chatter their delight in windless days of sunshine, and scoff at biting cold and wintry blasts. The nuthatch winds his tiny trumpet, the titmouse pipes his cheery note, the jay tries the innumerable tricks of his unmusical voice, and from their rollicking flight athwart the wavering slant of snowflakes drifts the creaking twitter of buntings.

The sharp, resonant strokes of the woodman's axe and the groaning downfall of the monarchs that it lays low, the shouts of teamsters, the occasional report of a gun, the various sounds of distant farmstead life, the jangle of sleigh bells on far-off highways, the rumbling roar of a railroad train rushing and panting along its iron path, and the bellowing of its far-echoed signals, all proclaim how busily affairs of life and 
pleasure still go on while the summerwearied earth lies wrapped in her winter sleep.

Night, stealing upon her in dusky pallor, under cloudy skies, or silvering her face with moonbeams and starlight, brings other and wilder voices. Solemnly the unearthly trumpet of the owl resounds from his woodland hermitage, the fox's gasping bark, wild and uncanny, marks at intervals his wayward course across the frozen fields on some errand of love or freebooting, and, swelling and falling with puff and lapse of the night wind, as mournful and lonesome as the voice of a vagrant spirit, comes from the mountain ridges the baying of a hound, hunting alone and unheeded, while his master basks in the comfort of his fireside.

218 


\section{XLVI}

\section{THE VARYING HARE}

IT is wonderful that with such a host of enemies to maintain himself against, the varying hare may still be counted as one of our familiar acquaintances. Except in the depths of the great wildernesses, he has no longer to fear the wolf, the wolverine, the panther, and the lesser felida, but where the younger woodlands have become his congenial home, they are also the home of a multitude of relentless enemies. The hawk, whose keen eyes pierce the leafy roof of the woods, wheels above him as he crouches in his form. When he goes abroad under the moon and stars, the terrible shadow of the horned owl falls upon his path, and the fox lurks beside it to waylay him, and the clumsy raccoon, waddling home from a cornfield revel, may blunder upon the timid wayfarer. 
But of all his enemies none is more inveterate than man, though he is not, as are the others, impelled by necessity, but only by that savagery, the survival of barbarism, which we dignify by the name of the sporting instinct.

Against them all,' how slight seem the defenses of such a weak and timid creature. Yet impartial nature, having compassed him about with foes, has shod his feet with swiftness and silence, and clad his body with an almost invisible garment. The vagrant zephyrs touch the fallen leaves more noisily than his soft pads press them. The first snow that whitens the fading gorgeousness of the forest carpet falls scarcely more silently.

Among the tender greens of early summer and the darker verdure of midsummer, the hare's brown form is as inconspicuous as a tuft of last year's leaves, and set in the brilliancy of autumnal tints, or the russet hue of their decay, it still eludes the eye. Then winter clothes him in her own whiteness so he may sit unseen upon her lap.

When he has donned his winter suit 
too early and his white coat is dangerously conspicuous on the brown leaves and among the misty gray of naked undergrowth, he permits your near approach as confidently as if he were of a color with his surroundings. Is he not aware that his spotless raiment betrays him, or does he trust that he may be mistaken for a white stone or a scroll of bark sloughed from a white birch? That would hardly save him from the keener-sensed birds and beasts of prey, but may fool your dull eyes.

In summer wanderings in the woods you rarely catch sight of him, though coming upon many faintly traced paths where he and his wife and their brown babies make their nightly way among the ferns. Nor are you often favored with a sight of him in more frequent autumnal tramps, unless when he is fleeing before the hounds whose voices guide you to a point of observation. He has now no eyes nor ears for anything but the terrible clamor that pursues him wherever he turns, however he doubles. If a shot brings him down and does not kill him, you will hear a cry so 
piteous that it will spoil your pleasant dreams of sport for many a night.

After a snowfall a single hare will in one night make such a multitude of tracks as will persuade you that a dozen have been abroad. Perhaps the trail is so intricately tangled with a purpose of misleading pursuit, perhaps it is but the record of saunterings as idle as your own.

As thus you wander through the pearl-enameled arches, your roving glances are arrested by a rounded form which, as white and motionless as everything around it, yet seems in some way not so lifeless. You note that the broad footprints end there, and then become aware of two wide, bright eyes, unblinkingly regarding you from the fluffy tuft of whiteness. How perfectly assured he is of his invisibility, and if he had but closed his bright eyes you might not guess that he was anything but a snow-covered clump of moss. How still and breathless he sits till you almost touch him, and then the white clod suddenly flashes into life and impetuous motion, bounding away in a 
halo of feathery flakes as if he himself were dissolving into white vapor.

Happy he, if he might so elude all foes; but alas for him, if the swiftwinged owl had been as close above him or the agile fox within leap. Then instead of this glimpse of beautiful wild life to treasure in your memory, you would only have read the story of a brief tragedy, briefly written, with a smirch of blood and a tuft of rumpled fur. 


\section{XLVII}

THE WINTER CAMP-FIRE

THE chief requisite of a winter campfire is volume. The feeble flame and meagre bed of embers that are a hot discomfort to the summer camper, while he hovers over coffee-pot and frying-pan, would be no more than the glow of a candle toward tempering this nipping air. This fire must be no dainty nibbler of chips and twigs that a boy's hatchet may furnish, but a roaring devourer of logs, for whose carving the axe must be long and stoutly wielded a very glutton of solid fuel, continually demanding more and licking with its broad red tongues at the branches that sway and toss high above in its hot breath.

So fierce is it that you approach cautiously to feed it and the snow shrinks away from it and can quench of it only the tiny sparks that are spit out upon it. 
You must not be too familiar with it, yet it is your friend after its own manner, fighting away for you the creeping demon of cold, and holding at bay, on the rim of its glare, the wolf and the panther.

With its friendly offices are mingled many elfish tricks. It boils your pot just to the point you wish, then boils it over and licks up the fragrant brew of celestial leaf or Javanese berry. It roasts or broils your meat to a turn, then battles with you for it and sears your fingers when you strive to snatch the morsel from its jaws, and perhaps burns it to a crisp before your very eyes, vouchsafing but the tantalizing fragrance of the feast.

Then it may fall into the friendliest and most companionable of moods, lazily burning its great billets of ancient wood while you burn the Virginian weed, singing to you songs of summer, its tongues of flame murmuring like the south wind among green leaves, and mimicking the chirp of the crickets and the cicada's cry in the simmer of exuding sap and vent of gas, and out of its smoke blos- 
som sparks, that drift away in its own currents like red petals of spent flowers.

It paints pictures, some weird or grotesque, some beautiful, now of ghosts and goblins, now of old men, now of fair women, now of lakes crinkled with golden waves and towers on pine-crowned crags ruddy with the glow of sunset, sunny meadows and pasture lands, with farmsteads and flocks and herds.

The ancient trees that rear themselves aloft like strong pillars set to hold up the narrow arch of darkness, exhale an atmosphere of the past, in which your thoughts, waking or sleeping, drift backward to the old days when men whose dust was long since mingled with the forest mould moved here in the rage of war and the ardor of the chase. Shadowy forms of dusky warriors, horribly marked in war paint, gather about the camp-fire and sit in its glare in voiceless council, or encircle it in the grotesquely terrible movement of the war dance.

Magically the warlike scene changes to one of peace. 'The red hunters steal 226 
silently in with burdens of game. The squaws sit in the ruddy light plying their various labors, while their impish children play around them in mimicry of battle and the chase.

All then vanish, and white-clad soldiers of France bivouac in their place or red-coated Britons, or Provincial rangers, unsoldierly to look upon, in homespun garb, but keen-eyed, alert, and the bravest of the brave.

These dissolve like wreaths of smoke, and a solitary white hunter, clothed all in buckskin, sits over against you. His long flint-lock rifle lying across his lap, he is looking with rapt gaze into the fire, dreaming as you are.

So, growing brighter as the daylight grows dim and the gloaming thickens to the mirk, and paling again as daylight creeps slowly back upon the world, but always bright in the diurnal twilight of the woods, the camp-fire weaves and breaks its magic spells, now leaping, now lapsing, as its own freaks move it. Then, perhaps, when it has charmed you far across the border of 


\section{THE WINTER CAMP-FIRE}

dreamland and locked your eyes in the blindness of sleep, it will startle you back to the cold reality of the wintry woods with a crash and roar of sudden revival. 


\section{XLVIII}

\section{JANUARY DAYS}

IN these midwinter days, how muffled is the earth in its immaculate raiment, so disguised in whiteness that familiar places are strange, rough hollows smoothed to mere undulations, deceitful to the eye and feet, and level fields so piled with heaps and ridges that their owners scarcely recognize them. The hovel is as regally roofed as the palace, the rudest fence is a hedge of pearl, finer than a wall of marble, and the meanest wayside weed is a white flower of fairyland.

The woods, which frost and November winds stripped of their leafy thatch, are roofed again, now with an arabesque of alabaster more delicate than the green canopy that summer unfolded, and all the floor is set in noiseless pavement, traced with a shifting pattern of blue shadows. In these silent aisles the echoes are smothered at their birth. 
There is no response of airy voices to the faint call of the winter birds. The sound of the axe-stroke flies no farther than the pungent fragrance of the smoke that drifts in a blue haze from the chopper's fire. The report of the gun awakes no answering report, and each mellow note of the hound comes separate to the ear, with no jangle of reverberations.

Fox and hound wallow through the snow a crumbling furrow that obliterates identity of either trail, yet there are tracks that tell as plain as written words who made them. Here have fallen, lightly as snowflakes, the broad pads of the hare, white as the snow he trod; there, the parallel tracks of another winter masker, the weasel, and those of the squirrel, linking tree to tree. The leaps of a tiny wood-mouse are lightly marked upon the feathery surface to where there is the imprint of a light, swift pinion on either side, and the little story of his wandering ends - one crimson blood drop the period that marks the finis.

In the blue shadow at the bottom of that winding furrow are the dainty foot- 
prints of a grouse, and you wonder why he, so strong of wing, should choose to wade laboriously the clogging snow even in his briefest trip, rather than make his easy way through the unresisting air, and the snow-written record of his wayward wanderings tells not why. Suddenly, as if a mine had been sprung where your next footstep should fall and with almost as startling, though harmless effect, another of his wild tribe bursts upward through the unmarked white floor and goes whirring and clattering away, scattering in powdery ruin the maze of delicate tracery the snowfall wrought; and vanishes, leaving only an aerial pathway of naked twigs to mark his impetuous passage.

In the twilight of an evergreen thicket sits a great horned owl like a hermit in his cell in pious contemplation of his own holiness and the world's wickedness. But this recluse hates not sin, only daylight and mankind. Out in the fields you may find the white-robed brother of this gray friar, a pilgrim from the far north, brooding in the very face of the sun, on some stack or outlying 
barn, but he will not suffer you to come so near to him as will this solemn anchorite who stares at you unmoved as a graven image till you come within the very shadows of his roof.

Marsh and channel are scarcely distinguishable now but by the white domes of the muskrats' winter homes and here and there a sprawling thicket or button bush, for the rank growth of weeds is beaten flat, and the deep snow covers it and the channel ice in one unbroken sheet.

Champlain's sheltered bays and coves are frozen and white with snow or frost, and the open water, whether still or storm-tossed, black beneath clouds or bluer than the blue dome that arches it, looks as cold as ice and snow. Sometimes its steaming breath lies close above it, sometimes mounts in swaying, lofty columns to the sky, but always cold and ghostly, without expression of warmth or life.

So far away to hoary peaks that shine with a glittering gleam against the blue rim of the sky, or to the furthest bluegray line of woodland that borders the 
horizon, stretches the universal whiteness, so coldly shines the sun from the low curve of his course, and so chilly comes the lightest waft of wind from wheresoever it listeth, that it tasks the imagination to picture any land on all the earth where spring is just awakening fresh life, or where summer dwells amid green leaves and bright flowers, the music of birds and running waters, and of warm waves on pleasant shores, or autumn yet lingers in the gorgeousness of many hues. How far off beyond this world seems the possibility of such seasons, how enduring and relentless this which encompasses us.

And then, at the close of the brief white day, the sunset paints a promise and a prophecy in a blaze of color on the sky. The gray clouds kindle with red and yellow fire that burns about their purple hearts in tints of infinite variety, while behind them and the dark blue rampart of the mountains flames the last glory of the departing sun, fading in a tint of tender green to the upper blue. Even the cold snow at our feet flushes with warm color, and the eastern hills 
blush roseate against the climbing, darkening shadow of the earth.

It is as if some land of summer whose brightness has never been told lay unveiled before us, its delectable mountains splendid with innumerable hues, its lakes and streams of gold rippling to purple shores seeming not so far before.

- us but that we might, by a little journey, come to them. 


\section{XLIX}

\section{A NEW ENGLAND WOODPILE}

When the charitable mantle of the snow has covered the ugliness of the earth, as one looks towards the woodlands he may see a distant dark speck emerge from the blue shadow of the woods and crawl slowly houseward. If born to the customs of this wintry land, he may guess at once what it is ; if not, speculation, after a little, gives way to certainty, when the indistinct atom grows into a team of quick-stepping horses or deliberate oxen hauling a sled-load of wood to the farmhouse.

It is more than that. It is a part of the woods themselves, with much of their wildness clinging to it, and with records, slight and fragmentary, yet legible, of the lives of trees and birds and beasts and men coming to our door.

Before the sounds of the creaking sled and the answering creak of the snow are 
heard, one sees the regular puffs of the team's breath jetting out and climbing the cold air. The head and shoulders of the muffled driver then appear, as he sticks by narrow foothold to the hinder part of his sled, or trots behind it beating his breast with his numb hands. Prone like a crawling band of scouts, endwise like battering-rams, not upright with green banners waving, Birnam wood comes to Dunsinane to fight King Frost.

As the woodpile grows at the farmhouse door in a huge windrow of sledlength wood or an even wall of cord wood, so in the woods there widens a patch of uninterrupted daylight. Deep shade and barred and netted shadow turn to almost even whiteness, as the axe saps the foundations of summer homes of birds and the winter fastnesses of the squirrels and raccoons. Here are the tracks of sled and team, where they wound among rocks and stumps and over cradle knolls to make up a load; and there are those of the chopper by the stump where he stood to fell the tree, and along the great trough made by its fall. The snow is flecked with chips, dark or pale accord. 236 
ing to their kind, just as they alighted from their short flight, bark up or down or barkless or edgewise, and with dry twigs and torn scraps of scattered moss.

When the chopper comes to his work in the morning, he finds traces of nightly visitors to his white island that have drifted to its shores out of the gray sea of woods. Here is the print of the hare's furry foot where he came to nibble the twigs of poplar and birch that yesterday were switching the clouds, but have fallen, manna-like, from skyward to feed him. A fox has skirted its shadowy margin, then ventured to explore it, and in a thawy night a raccoon has waddled across it.

The woodman is apt to kindle a fire more for company than warmth, though he sits by it to eat his cold dinner, casting the crumbs to the chickadees, which come fearlessly about him at all times. Blazing or smouldering by turns, as it is fed or starved, the fire humanizes the woods more than the man does. Now and then it draws to it a visitor, oftenest a fox-hunter who has lost his hound, and stops for a moment to light his pipe 
at the embers and to ask if his dog has been seen or heard. Then he wades off through the snow, and is presently swallowed out of sight by gray trees and blue shadows. Or the hound comes in search of his master or a lost trail. $\mathrm{He}$ halts for an instant, with a wistful look on his sorrowful face, then disappears, nosing his way into the maw of the woods.

If the wood is cut "sled length," which is a saving of time and also of chips, which will now be made at the door and will serve to boil the tea-kettle in summer, instead of rotting to slow fertilization of the woodlot, the chopper is one of the regular farm hands or a "day man," and helps load the sled when it comes. If the wood is four foot, he is a professional, chopping by the cord, and not likely to pile his cords too high or long, nor so closely that the squirrels have much more trouble in making their way through them than over them; and the man comes and goes according to his ambition to earn money.

In whichever capacity the chopper plies his axe, he is pretty sure to bring 238 
no sentimentalism to his task. He inherits the feeling that was held by the old pioneers toward trees, who looked upon the noblest of them as only giant weeds, encumbering the ground, and best got rid of by the shortest means. To him the tree is a foe worthy of no respect or mercy, and he feels the triumph of a savage conquerer when it comes crashing down and he mounts the prostrate trunk to dismember it; the more year-marks encircling its heart, the greater his victory. To his ears, its many tongues tell nothing, or preach only heresy. Away with the old tree to the flames! To give him his due, he is a skillful executioner, and will compel a tree to fall across any selected stump within its length. If one could forget the tree, it is a pretty sight to watch the easy swing of the axe, and see how unerringly every blow goes to its mark, knocking out chips of a span's breadth. It does not look difficult nor like work; but could you strike "twice in a place," or in half a day bring down a tree twice as thick as your body? The wise farmer cuts, for fuel, only the dead and decaying 
trees in his woodlot, leaving saplings and thrifty old trees to "stand up and grow better," as the Yankee saying is.

There is a prosperous and hospitable look in a great woodpile at a farmhouse door. Logs with the moss of a hundred years on them, breathing the odors of the woods, have come to warm the inmates and all in-comers. The white smoke of these chimneys is spicy with the smell of seasoned hard wood, and has a savor of roasts and stews that makes one hungry. If you take the back track on a trail of pitchy smoke, it is sure to lead you to a squalid threshold with its starved heap of pine roots and half-decayed wood. Thrown down carelessly beside it is a dull axe, wielded as need requires with spiteful awkwardness by a slatternly woman, or laboriously upheaved and let fall with uncertain stroke by a small boy.

The Yankees who possess happy memories of the great open fires of old time are growing few, but Whittier has embalmed for all time, in "Snow-Bound," their comfort and cheer and picturesqueness. When the trees of the virgin forest cast their shadows on the newly risen roof 240 
there was no forecasting provision for winter. The nearest green tree was cut, and hauled, full length, to the door, and with it the nearest dry one was cut to match the span of the wide fireplace; and when these were gone, another raid was made upon the woods; and so from hand to mouth the fire was fed. It was not uncommon to draw the huge backlogs on to the hearth with a horse, and sometimes a yoke of oxen were so employed. Think of a door wide enough for this: half of the side of a house to barricade against the savage Indians and savage cold! It was the next remove from a camp-fire. There was further likeness to it in the tales that were told beside it, of hunting and pioneer hardships, of wild beasts and Indian forays, while the eager listeners drew to a closer circle on the hearth, and the awed children cast covert scared backward glances at the crouching and leaping shadows that thronged on the walls, and the great samp-kettle bubbled and seethed on its trammel, and the forgotten johnny-cake scorched on its tilted board.

As conveniently near the shed as pos- 
sible, the pile of sled-length wood is stretching itself slowly, a huge vertebrate, every day or two gaining in length; a joint of various woods, with great trunks at the bottom, then smaller ones, gradually growing less to the topping out of saplings and branches. Here is a sugarmaple, three feet through at the butt, with the scars of many tappings showing on its rough bark. The oldest of them may have been made by the Indians. Who knows what was their method of tapping? Here is the mark of the gouge with which early settlers drew the blood of the tree; a fashion learned, likely enough, from the aboriginal sugar-makers, whose narrowest stone gouges were as passable tools for the purpose as any they had for another. These more distinct marks show where the auger of later years made its wounds. The old tree has distilled its sweets for two races and many generations of men, first into the bark buckets of Waubanakis, then into the ruder troughs of Yankee pioneers, then into the more convenient wide-bottomed wooden sap-tubs ; and at last, when the march of improvement has spoiled the wilderness 
of the woods with trim-built sugar-houses and patent evaporators, the sap drips with resounding metallic tinkle into pails of shining tin. Now the old maple has come to perform its last office, of warming and cooking the food for a generation that was unborn when it was yet a lusty tree.

Beside it lies a great wild-cherry tree that somehow escaped the cabinet maker when there was one in every town and cherry wood was in fashion. Its fruit mollified the harshness of the New England rum of many an old-time raising and husking. Next is a yellow birch with a shaggy mane of rustling bark along its whole length, like a twelve-foot piece of the sea serpent drifted ashore and hauled inland; then a white birch, no longer white, but gray with a coating of moss, and black with belts of old peelings, made for the patching of canoes and roofing of shanties.

With these lies a black birch, whose once smooth bark age has scaled and furrowed, and robbed of all its tenderness and most of its pungent, aromatic flavor. Some of it yet lingers in the younger top- 
most twigs which the hired man brings home to the little folks, who fall to gnawing them like a colony of beavers. By it is an elm, whose hollow trunk was the home of raccoons when it stood on its buttressed stump in the swamp. Near by is a beech, its smooth bark wrinkled where branches bent away from it, and blotched with spots of white and patches of black and gray lichen. It is marked with innumerable fine scratches, the track of the generations of squirrels that have made it their highway; and among these, the wider apart and parallel nail-marks of a raccoon, and also the drilling of woodpeckers. Here, too, are traces of man's visitation, for distorted with the growth of years are initials, and a heart and dart that symbolized the tender passion of some one of the past, who wandered, love-sick, in the shadow of the woods. How long ago did death's inevitable dart pierce his heart? Here he wrote a little of his life's history, and now his name and that of his mistress are so completely forgotten one cannot guess them by their first letters inscribed in the yesterday of the forest's years. 
Above these logs, rolled up on skids or sled stakes, are smaller yet goodly bodies of white ash, full of oars for the water and rails for the land ; and of black ash, as full of barrel hoops and basket splints, the ridged and hoary bark shagged with patches of dark moss; and a pine too knotty for sawing, with old turpentine boxes gashing its lower part, the dry resin in them half overgrown, but odorous still; and oaks that have borne their last acorns; and a sharded hickory that will never furnish another nut for boy or squirrel, but now, and only this once, flail handles, swingles, and oxbows, and helves for axes to hew down its brethren, and wood to warm its destroyers, and smoke and fry ham for them; and a basswood that will give the wild bees no more blossoms in July, hollow-hearted and unfit for sleigh or toboggan, wood straight rifted and so white that a chip of it will hardly show on the snow, but as unprofitable food for fires as the poplars beside it, which, in the yellow-green of youth or the furrowed gray of age, have shivered their last.

Still higher in the woodpile are white 
birches, yet in the smooth skin of their prime, which is fit to be fashioned into drinking cups and berry baskets, or to furnish a page for my lady's album. Here are hardhacks, some with grain winding like the grooves of a rifle. This is the timber the Indians made their bows of, and which now serves the same purpose for the young savages whom we have always with us. There are sinewy blue beeches, slowly grown up from ox-goads and the "beech seals" of Ethan Allen's Green Mountain Boys to the girth of a man's thigh, a size at which they mostly stop growing. A smaller trunk, like yet unlike them, sets folks to guessing what kind of wood it is. He will hit the mark who fires at random the names "shadblow," " service- berry," or " amelanchier." If the axe had been merciful, in early May its branches would have been as white with blossoms as if the last April snow still clung to them. Tossed on a-top of all is a jumbled thatch of small stuff, - saplings improvidently cut, shortlived striped maple, and dogwood, the slender topmost lengths of great trees, once the perches of hawks and crows, 246 
and such large branches as were not too crooked to lie still on the sled.

The snow-fleas, harbingers and attendants of thaws, are making the snow in the woods gray with their restless myriads, when the sled makes its last trip across the slushy fields, which are fast turning from white to dun under the March winds and showers and sunshine.

The completed woodpile basks in the growing warmth, as responsive to the touch of spring as if every trunk yet upheld its branches in the forest. The buds swell on every chance-spared twig, and sap starts from the severed ducts. From the pine drip slowly lengthening stalactites of amber, from the hickory thick beads of honeydew, and from the maples a flow of sweet that calls the bees from their hives across the melting drifts. Their busy hum makes an island of summer sound in the midst of the silent ebbing tide of winter.

As the days grow warmer, the woodpile invites idlers as well as busy bees and wood-cutters. The big logs are comfortable seats to lounge on while whittling a pine chip, and breathing the min- 


\section{A NEW ENGLAND WOODPILE}

gled odors of the many woods freshly cut and the indescribable woodsy smell brought home in the bark and moss, and listening to the hum of the bees and harsher music of the saws and axe, the sharp, quick swish of the whip-saw, the longer drawn and deeper ring of the crosscut, and the regular beat of the axe, fiddle, bass-viol, and drum, each with its own time, but all somehow in tune. The parts stop a little when the fiddler saws off his string, the two drawers of the long bass-viol bow sever theirs, and the drummer splits his drum, but each is soon outfitted again, and the funeral march of the woodpile goes on. Here is the most delightful of places for those busy idlers the children, for it is full of pioneers' and hunters' cabins, robbers' caves and bears' dens, and of treasures of moss and gum and birch, and of punk, the tinder of the Indians and our forefathers, now gone out of use except for some conservative Canuck to light his pipe or for boys to touch off their small ordnance.

It is a pretty sight to watch the nuthatches and titmice searching the grooves of the bark for their slender fare, or a 248 


\section{A NEW ENGLAND WOODPILE}

woodpecker chopping his best for a living with his sharp-pointed axe, all having followed their rightful possessions from the woods, taking perhaps the track of the sled. It is wonderful to hear the auger of the pine-borer, now thawed into life, crunching its unseen way through the wood. Then there is always the chance of the axe unlocking the stores of deermice, quarts of beechnuts with all the shells neatly peeled off ; and what if it should happen to open a wild-bee hive full of honey!

If the man comes who made the round of the barns in the fall and early winter with his threshing-machine, having exchanged it for a sawing machine, he makes short work of our woodpile. A day or two of stumbling clatter of the horses in their treadmill, and the buzzing and screeching of the whirling saw, gnaws it into a heap of blocks.

Our lounging-place and the children's wooden playground have gone, and all the picturesqueness and woodsiness have disappeared as completely as when splitting has made only firewood of the pile. It will give warmth and comfort from 
A NEW ENGLAND WOODPILE

the stove, but in that black sepulchre all its beauty is swallowed out of sight forever. If it can go to a generous fireplace, it is beautified again in the glowing and fading embers that paint innumerable shifting pictures, while the leaping flames sing the old song of the wind in the branches. 


\section{$\mathbf{L}$}

A CENTURY OF EXTERMINATION

IT seems quite probable that this nineteenth century may be unpleasantly memorable in centuries to come as that in which many species of animate and inanimate nature became extinct. It has witnessed the extinction of the great auk, so utterly swept off the face of the earth that the skin, or even the egg of one, is a small fortune to the possessor. Reduced from the hundreds of thousands of twenty-five years ago to the few hundred of to-day, it needs but a few years to compass the complete annihilation of the bison. It is not improbable that the elk and the antelope will be overtaken by almost as swift a fate. The skin hunters, and the game butchers miscalled sportsmen, are making almost as speedy way with them as they have with the buffalo.

The common deer, hedged within 25 I 
their narrowing ranges by civilization, and hunted by all methods in all seasons, may outlast the century, but they will have become wofully scarce at the close of it, even in such regions as the Adirondacks, which seem to have been set apart by nature especially for the preservation of wild life.

The wild turkey is passing away, and it is a question of but few years when he shall have departed forever. In some localities the next noblest of our game birds, the ruffed grouse, has become almost a thing of the past, and in some years is everywhere so scarce that there are sad forebodings of his complete disappearance from the rugged hills of which he seems as much a belonging as the lichened rocks, the arbutus and the wind-swept evergreens. One little island on the New England coast holds the handful that is left of the race of heath hens.

The woodcock is being cultivated and improved and murdered out of existence with clearing and draining and summer shooting, and unseasonable shooting is doing the same for many kinds of water- 
fowl. In the Eastern States a wild pigeon is a rare sight now, and has been for years; the netters and slaughterers have done their work too thoroughly.

Gentle woman is making an end of the song-birds that she may trick her headgear in barbaric and truly savage fashion. The brighter plumaged small birds are becoming noticeably scarce even in those parts of the country that the milliners' collector and the pot-naturalist have not yet invaded, and such as the scarlet tanager, never anywhere numerous, are like to be soon "collected" out of living existence. If they are to be saved, it is by no dallying, nor slow awakening of popular feeling in their behalf.

There will be pine-trees, no doubt, for centuries to come, but who that live twenty years hence will see one of these venerable monarchs of the woods towering above all other forest growth, or see any ancient tree, however historic or precious for its age and beauty and majesty and mystery of long past years, if it is worth the cutting for timber or fuel ?

Even the lesser growths of the old woods are passing away. Some, as the 


\section{A CENTURY OF EXTERMINATION}

carpeting sphagnum and the sprawling hobble bush, disappear through changed conditions; others, as the medicinal spikenard, sarsaparilla, and ginseng, and the decorative running pine and the arbutus, through ruthless, greedy gathering, which leaves no root nor ripened seed to perpetuate their kind.

An old man may be glad that his eyes are not to behold the coming desolation, but he must be sad when he thinks of the poor inheritance of his children.

254 
THE PERSISTENCY OF PESTS

From the sowing and planting of his seed, almost indeed from the turning of the furrow, the farmer enters upon a contest with the weeds, for a place in which his crops may grow, and if he or the crops are not vanquished, as the weeds never are, the warfare continues till harvest time.

While he, with infinite labor, prepares the ground and sows his seed with all care, praying that drouth may not wither nor floods drown it, and that frosts may not cut down the tender plants, the winds of heaven and the fowls of the air scatter broadcast the seeds of the noxious weeds, or these lie dormant in the ground awaiting opportunity. They germinate in sterile places, fence corners and nooks of the wayside, and flourish alike in scorching sunshine and in sodden soil. 
Weeds defy the latest and the earliest frosts, grow with their roots in the air ; and cut down, spring up, grow on, blossoming and ripening their seed in creeping stealth and ever unscathed by blight; and so flourish in spite of all unkindliness of man or stress of nature, that the husbandman wishes that they might by some freak of demand become the useful plants, his present crop the undesired ones.

Somewhat the same position in which weeds stand opposed to the plants which the husbandman depends upon-for his livelihood, vermin hold toward the beasts and birds upon which the sportsman depends for his recreation. While they whose protection men endeavor to maintain during the season of procreation, and at times when scarcity of food prevails, decrease often to complete extinction, the vermin, whom the hand of man is always against, continue to increase and multiply, or at least hold their own. With them as with the weeds nature seems to deal with a kinder hand. She spares and nourishes them, while she destroys their betters. 
The snow crust, which walls the quail in a living tomb, makes a royal banqueting hall for the pestiferous field mice, where they feast and revel in plenty, secure from all their enemies, feathered or furred. It impounds the deer, but gives free range to the wolf and to his as pitiless two-legged brother, the crust hunter.

The wet seasons that drown the callow woodcock and grouse work no harm to the ravenous brood of the hawk and owl, nor to the litter of fox, mink, or weasel. Wet or dry, hot or cold, the year fosters them throughout its varied round.

Winged ticks kill the grouse, but the owl endures their companionship with sedate serenity and thrives with a swarm of the parasites in the covert of his feathers.

The skunk has always been killed on sight as a pest that the world would be the sweeter for being rid of. In later years the warfare against him has received an impetus from the value of his fur, but though this has gone on relentlessly for many years, his tribe still live 
to load the air with a fragrance that incites the ambitious trapper to further conquest.

All the year round, farmers and their boys wage war upon the crows, but each returning autumn sees the columns of the black army moving southward with apparently unthinned ranks, while, year by year, the harried platoons of ducks and geese return fewer and less frequent. Those detested foreigners, the English sparrows, increase and multiply in spite of bitter winters and righteous persecution, while our natives, the beloved song-birds, diminish in numbers. On every hand we find the undesirable in animated nature, the birds and beasts that we would gladly be rid of, maintaining their numbers, while those whose increase we desire are losing ground and tending toward extinction.

The prospect for the sportsman of the future is indeed gloomy, unless he shall make game of the pests and become a hunter of skunks and a shooter of crows and sparrows. Who can say that a hun$25^{8}$ 
dred years hence the leading sportsmen of the period will not be wrangling over the points and merits of their skunk and woodchuck dogs and bragging of their bags of crows and sparrows ?

259 


\section{LII}

THE WEASEL

A chain that is blown away by the wind and melted by the sun, links with pairs of parallel dots the gaps of farm fences, and winds through and along walls and zigzag lines of rails, is likely to be the most visible sign that you will find in winter of one bold and persistent little hunter's presence.

Still less likely are you to be aware of it in summer or fall, even by such traces of his passage, for he is in league with nature to keep his secrets. When every foot of his outdoor wandering must be recorded she makes him as white as the snow whereon it is imprinted, save his beady eyes and dark tail-tip. When summer is green and autumn gay or sad of hue she clothes him in the brown wherewith she makes so many of her wild children inconspicuous.

Yet you may see him, now and then, 260 
in his white suit or in his brown, gliding with lithe, almost snake-like movement along the lower fence rails, going forth hunting or bearing home his game, a bird or a fat field-mouse. In a cranny of an old lichen-scaled stone wall you may see his bright eyes gleaming out of the darkness, like dewdrops caught in a spider's web, and then the brown head thrust cautiously forth to peer curiously at you. Then he may favor you with the exhibition of an acrobatic feat: his hinder paws being on the ground in the position of standing, he twists his slender body so that his forepaws are placed in just the reverse position on the stone or rail above him, and he looks upward and backward.

He may be induced to favor you with intimate and familiar acquaintance, to take bits of meat from your hand and even to climb to your lap and search your pockets and suffer you to lay a gentle hand upon him, but he has sharp teeth wherewith to resent too great liberties.

While he may be almost a pet of a household and quite a welcome visitor of $26 \mathrm{I}$ 
rat-infested premises, he becomes one of the worst enemies of the poultry-wife when he is tempted to fall upon her broods of chicks. He seems possessed of a murderous frenzy, and slays as ruthlessly and needlessly as a wolf or a human game-butcher or the insatiate angler. Neither is he the friend of the sportsman, for he makes havoc among the young grouse and quail and the callow woodcock.

The trapper reviles him when he finds him in his mink trap, for all the beauty of his ermine a worthless prize drawn in this chanceful lottery. When every one carried his money in a purse, the weasel's slender white skin was in favor with country folk. This use survives only in the command or exhortation to "draw your weasel." When the purse was empty, it gave the spendthrift an untimely hint by creeping out of his pocket. In the primest condition of his fur he neither keeps nor puts money in your pocket now. $\mathrm{He}$ is worth more to look at, with his lithe body quick with life, than to possess in death. 


\section{LIII}

FEBRUARY DAYS

IN the blur of storm or under clear skies, the span of daylight stretches farther from the fading dusk of dawn to the thickening dusk of evening. Now in the silent downfall of snow, now in the drift and whirl of flakes driven from the sky and tossed from the earth by the shrieking wind, the day's passage is unmarked by shadows. It is but a long twilight, coming upon the world out of one misty gloom, and going from it into another. Now the stars fade and vanish in the yellow morning sky, the long shadows of the hills, clear cut on the shining fields, swing slowly northward and draw eastward to the netted umbrage of the wood. So the dazzling day grows and wanes and the attenuated shadows are again stretched to their utmost, then dissolved in the flood of shade, and the pursued sunlight takes flight from the 263 
mountain peaks to the clouds, from cloud to cloud along the darkening sky, and vanishes beyond the blue barrier of the horizon.

There are days of perfect calm and hours of stillness as of sleep, when the lightest wisp of cloud fleece hangs moveless against the sky and the pine-trees forget their song. But for the white columns of smoke that, unbent in the still air, arise from farmstead chimneys, one might imagine that all affairs of life had been laid aside; for no other sign of them is visible, no sound of them falls upon the ear. You see the cows and sheep in the sheltered barnyards and their lazy breaths arising in little clouds, but no voice of theirs drifts to you.

No laden team crawls creaking along the highway nor merry jangle of sleigh bells flying into and out of hearing over its smooth course, nor for a space do the tireless panting engine and roaring train divide earth and sky with a wedge of dissolving vapor. The broad expanse of the lake is a white plain of snow-covered ice: no dash of angry waves assails its shore still glittering with the trophies of 264 
their last assault ; no glimmer of bright waters greets the sun; no keel is afloat; the lighthouse, its occupation gone, stares day and night with dull eyes from its lonely rock, upon a silent deserted waste.

In the wood you may hear no sound but your own muffled footsteps, the crackle of dry twigs, and the soft swish of boughs swinging back from your passage, and now and then a tree punctuating the silence with a clear resonant crack of frozen fibres and its faint echo. You hear no bird nor squirrel nor sound of woodman's axe, nor do you catch the pungent fragrance of his fire nor the subtler one of fresh-cut wood. Indeed, all odors of the forest seem frozen out of the air or locked up in their sources. No perfume drops from the odor-laden evergreens, only scentless air reaches your nostrils.

One day there comes from the south a warm breath, and with it fleets of white clouds sailing across the blue upper deep, outstripped by their swifter shadows sweeping in blue squadrons along the glistening fields and darkening 265 
with brief passage the gray woodlands. Faster come the clouds out of the south and out of the west, till they crowd the sky, only fragments of its intense azure showing here and there between them, only now and then a gleam of sunlight flashing across the earth. Then the blue sunlit sky is quite shut away behind a low arch of gray, darkening at the horizon with thick watery clouds, and beneath it all the expanse of fields and forest lies in universal shadow.

The south wind is warmer than yesterday's sunshine, the snow softens till your footsteps are sharply moulded as in wax, and in a little space each imprint is flecked thick with restless, swarming myriads of snow-fleas. Rain begins to fall softly on snow-covered roofs, but beating the panes with the familiar patter of summer showers. It becomes a steady downpour that continues till the saturated snow can hold no more, and the hidden brooks begin to show in yellow streaks between white, unstable shores, and glide with a swift whisking rush over the smooth bottom that paves their rough natural bed; and as their 266 
yellow currents deepen and divide more widely their banks, the noise of their onflow fills the air like an exaggeration of the murmur of pines, and the song of the pines swells and falls with the varying wind.

After the rain there come, perhaps, some hours of quiet sunshine or starlight, and then out of the north a nipping wind that hardens the surface of the snow into solid crust that delights your feet to walk upon. The rivulets shrink out of sight again, leaving no trace but water-worn furrows in the snow, some frozen fluffs of yellow foam and stranded leaves and twigs, grass and broken weeds. The broad pools have left their shells of unsupported ice, which with frequent sudden crashes shatters down upon their hollow beds.

When the crust has invited you forth, you cannot retrace your way upon it, and the wild snow walkers make no record now of their recent wanderings. But of those who fared abroad before this solid pavement was laid upon the snow, fabulous tales are now inscribed upon it. Reading them without ques267 
tion, you might believe that the welltamed country had lapsed into the possession of its ancient savage tenants, for the track of the fox is as big as a wolf's, the raccoon's as large as a bear's, the house cat's as broad as the panther's, and those of the muskrat and mink persuade you to believe that the beaver and otter, departed a hundred years ago, have come to their own again. Till the next thaw or snowfall, they are set as indelibly as primeval footprints in the rocks, and for any scent that tickles the hounds' keen nose, might be as old. He sniffs them curiously and contemptuously passes on, yet finds little more promising on footing that retains but for an instant the subtle trace of reynard's unmarked passage.

The delicate curves and circles that the bent weeds etched on the soft snow are widened and deepened in rigid grooves, wherein the point that the fingers of the wind traced them with is frozen fast. Far and wide from where they fall, all manner of seeds drift across miles of smooth fields, to spring to life and bloom, by and by, in strange, unac268 
customed places, and brown leaves voyage to where their like was never grown. The icy knolls shine in the sunlight with dazzling splendor, like golden islands in a white sea that the north wind stirs not, and athwart it the low sun and the waning moon cast their long unrippled glades of gold and silver. Over all winter again holds sway, but we have once more heard the sound of rain and running brooks and have been given a promise of spring. 


\section{LIV}

THE FOX

Among the few survivals of the old untamed world there are left us two that retain all the raciness of their ancestral wildness.

Their wits have been sharpened by the attrition of civilization, but it has not smoothed their characteristics down to the level of the commonplace, nor contaminated them with acquired vices as it has their ancient contemporary, the Indian. But they are held in widely different esteem, for while the partridge is in a manner encouraged in continuance, the fox is an outlaw, with a price set upon his head to tempt all but his few contemned friends to compass his extermination.

For these and for him there is an unwritten code that, stealthily enforced, gives him some exemption from universal persecution. They, having know270 
ledge of the underground house of many portals where the vixen rears her cubs, guard the secret as jealously as she and her lord, from the unfriendly farmer, poultry-wife, and bounty-hunting vagabond, confiding it only to sworn brethren of woodcraft, as silent concerning it to the unfriendly as the trees that shadow its booty-strewn precincts or the lichened rocks that fortify it against pick and spade. They never tell even their leashed hounds till autumn makes the woods gayer with painted leaves than summer could with blossoms, how they have seen the master and mistress of this woodland home stealing to it with a fare of field mice fringing their jaws or bearing a stolen lamb or pullet.

They watch from some unseen vantage, with amused kindliness, the gambols of the yellow cubs about their mother, alert for danger, even in her drowsy weariness, and proud of her impish brood, even now practicing tricks of theft and cunning on each other. They become abetters of this family's sins, apologists for its crimes, magnifiers of its unmeant well-doing. 
When in palliation of the slaughter of a turkey that has robbed a field of his weight in corn they offset the destruction of hordes of field mice, they are reviled by those who are righteously exalted above the idleness of hunting and the foolishness of sentiment.

At such hands one fares no better who covets the fox, not for the sport he may give, but for the tang of wild flavor that he imparts to woods that have almost lost it and to fields that lose nothing of thrift by its touch.

You may not see him, but it is good to know that anything so untamed has been so recently where your plodding footsteps go. You see in last night's snowfall the sharp imprint of his pads, where he has deviously quested mice under the mat of aftermath, or trotted slowly, pondering, to other more promising fields, or there gone airily coursing away over the moonlit pastures. In imagination you see all his agile gaits and graceful poses. Now listening with pricked ears to the muffled squeak of a mouse, now pouncing upon his captured but yet unseen prize, or where on sud- 
den impulse he has coursed to fresh fields, you see him, a dusky phantom, gliding with graceful undulations of lithe body and brush over the snowy stretches; or, halting to wistfully sniff, as a wolf a sheepfold, the distant henroost; or, where a curious labyrinth of tracks imprint the snow, you have a vision of him dallying with his tawny sweetheart under the stars of February skies; or, by this soft mould of his furry form on a snow-capped stump or boulder, you picture him sleeping off the fatigue of hunting and love-making, with all senses but sight still alert, unharmed by the nipping air that silvers his whiskers with his own breath.

All these realities of his actual life you may not see except in such pictures as your fancy makes; but when the woods are many-hued or brown in autumn, or gray and white in winter, and stirred with the wild music of the hounds, your blood may be set tingling by the sight of him, his coming announced by the rustle of leaves under his light footfalls. Perhaps unheralded 
by sound, he suddenly blooms ruddily out of the dead whiteness of the snow.

Whether he flies past or carefully picks his way along a fallen tree or bare ledge, you remark his facial expression of incessant intentness on cunning devices, while ears, eyes, and nose are alert for danger. If he discovers you, with what ready self-possession he instantly gets and keeps a tree between himself and you and vanishes while your gun vainly searches for its opportunity. If your shot brings him down, and you stand over him exultant, yet pitying the end of his wild life, even in his death throes fearing you no more, he yet strains his dulled ears to catch the voices of the relentless hounds.

Bravely the wild freebooter holds his own against the encroachments of civilization and the persecution of mankind, levying on the flocks and broods of his enemy, rearing his yellow cubs in the very border of his field, insulting him with nightly passage by his threshold.

Long ago his fathers bade farewell to their grim cousin the wolf, and saw the beaver and the timid deer pass away, 
and he sees the eagle almost banished from its double realm of earth and sky, yet he hardily endures. For what he preserves for us of the almost extinct wildness, shall we begrudge him the meagre compensation of an occasional turkey?

275 


\section{LV}

\section{AN ICE-STORM}

OF all the vagaries of winter weather, one of the rarest is the ice-storm; rain falling with a wind and from a quarter that should bring snow, and freezing as it falls, not penetrating the snow but coating it with a shining armor, sheathing every branch and twig in crystal and fringing eaves with icicles of most fantastic shapes.

On ice-clad roofs and fields and crackling trees the rain still beats with a leaden clatter, unlike any other sound of rain; unlike the rebounding pelting of hail or the swish of wind-blown snow.

The trees begin to stoop under their increasing burden, and then to crack and groan as it is laid still heavier upon them. At times is heard the thin, echoless crash of an overladen branch, first bending to its downfall with a gathering crackle of severed fibres, then with a 276 
sudden crash, shattering in a thousand fragments the. brief adornments that have wrought its destruction.

Every kind of tree has as marked individuality in its icy garniture as in its summer foliage. The gracefulness of the elms, the maples, the birches, the beeches, and the hornbeams is preserved and even intensified; the clumsy ramage of the butternut and ash is as stiff as ever, though every unbending twig bears its row of glittering pendants. The hemlocks and firs are tents of ice, but the pines are still pines, with every needle exaggerated in bristling crystal.

Some worthless things have become of present value, as the wayside thistles and the bejeweled grass of an unshorn meadow, that yesterday with its dun unsightliness, rustling above the snow, proclaimed the shiftlessness of its owner.

Things most unpicturesque are made beautiful. The wire of the telegraph with its dull undulations is transformed to festoons of crystal fringe, linking together shining pillars of glass that yesterday were but bare, unsightly posts.

The woods are a maze of fantastic 
shapes of tree growth. Wood roads are barricaded with low arches of ice that the hare and the fox can barely find passage beneath, and with long, curved slants of great limbs bent to the earth. The wild vines are turned to ropes and cables of ice, and have dragged down their strong supports, about whose prostrate trunks and limbs they writhe in a tangle of rigid coils. The lithe trunks of second growth are looped in an intricate confusion of arches one upon another, many upon one, over whole acres of low-roofed forest floor.

The hare and the grouse cower in these tents of ice, frightened and hungry; for every sprout and bud is sheathed in adamant, and scarlet berries, magnified and unattainable, glow in the heart of crystal globules. Even the brave chickadees are appalled, and the disheartened woodpecker mopes beside the dead trunk, behind whose impenetrable shield he can hear the grub boring in safety.

Through the frozen brambles that lattice the doorway of his burrow the fox peers dismayed upon a glassy surface that will hold no scent of quarry, yet 278 
perhaps is comforted that the same conditions impose a truce upon his enemies the hounds. The squirrel sits fasting in his chamber, longing for the stores that are locked from their owner in his cellar. It is the dismalest of all storms for the wood folk, despite all the splendor wherewith it adorns their realm.

One holds out his hand and lifts his face skyward to assure himself that the rain has ceased, for there is a continual clattering patter as if it were yet falling. But it is only the crackling of the icy trees and the incessant dropping of small fragments of their burden.

The gray curtain of the sky drifts asunder, and the low sun shines through. It glorifies the earth with the flash and gleam of ten million diamonds set everywhere. The fire and color of every gem that was ever delved burn along the borders of the golden pathway that stretches from your feet far away to the silver portals of the mountains that bar our glittering world from the flaming sky.

The pallid gloom of the winter night falls upon the earth. Then the full moon throbs up behind the scintillating barrier 
of the hills. She presently paves from herself to us a street of silver among the long blue shadows, and lights it with a thousand stars; some fallen quite to earth, some twinkling among the drooping branches, all as bright as the eternal stars that shine in the blue sky above. 280 


\section{LVI}

SPARE THE TREES

All the protection that the law can give will not prevent the game naturally belonging to a wooded country from leaving it when it is deforested, nor keep fish in waters that have shrunk to a quarter of their ordinary volume before midsummer. The streams of such a country will thus shrink when the mountains, where the snows lie latest and the feeding springs are, and the swamps, which dole out their slow but steady tribute, are bereft of shade. The thin soil of a rocky hill, when deprived of its shelter of branches, will be burned by the summer sun out of all power to help the germination of any worthy seed, or to nurture so noble a plant as a tree through the tender days of its infancy. It supports only useless weeds and brambles. Once so denuded, it will be unsightly and unprofitable for many 28r 
years if not always. Some swamps at great expense may be brought into tillage and meadow, but nine times out of ten, when cleared of the lusty growth of woods, they bear nothing but wild grass, and the streams that trickled from them all the summer long in their days of wildness show in August only the parched trail of the spring course.

Our natives have inherited their ancestors' hatred of trees, which to them were only cumberers of the ground, to be got rid of by the speediest means; and our foreign-born landholders, being unused to so much woodland, think there can be no end to it, let them slash away as they will.

Ledges and steep slopes that can bear nothing but wood to any profit, are shorn of their last tree, and the margins of streams to the very edge robbed of the willows and water-maples that shaded the water and with their roots protected the banks from washing. Who has not known a little alder swamp, in which he was sure to find a dozen woodcock, when he visited it on the first day of the season each year?. Some year the first day 282 
comes and he seeks it as usual, to find its place marked only by brush heaps, stubs, and sedges; and for the brook that wimpled through it in the days of yore, only stagnant pools. The worst of it is, the owners can seldom give any reason for this slaughter but that their victims were trees and bushes.

The Yankee, with his proverbial thriftiness and forecast, appears entirely to lose these gifts when it comes to the proper and sensible management of woodlands. Can he not understand that it is more profitable to keep a lean or thin soil that will grow nothing well but wood, growing wood instead of worthless weeds? The crop is one which is slow in coming to the harvest, but it is a sure one, and is every year becoming a more valuable one. It breaks the fierceness of the winds, and keeps the springs from drying up, and is a comfort to the eye, whether in the greenness of the leaf or the barrenness of the bough, and under its protecting arms live and breed the grouse, the quail and the hare, and in its shadowed rills swim the trout. 


\section{LVII}

THE CHICKADEE

THE way to the woods is blurred with a mist of driven snow that veils the portal of the forest with its upblown curtain, and blots out all paths, and gives to the familiar landmarks a ghostly unreality. The quietude of the woods is disturbed by turbulent voices, the angry roar and shriek of the wind, the groaning and clashing of writhing, tormented trees. Over all, the sunned but unwarmed sky bends its blue arch, as cold as the snowy fields and woods beneath it.

In such wild weather you are not tempted far abroad in quest of old acquaintances of fields and woods, yet from the inhospitable woods some of them come to you. Among them all, none is more welcome than that feathered atom of life, the chickadee. With the same blithe note that welcomed you to his woodland haunts in spring, in summer, 284 
and in autumn, when he attended you with such charming familiarity, amusing you with pretty acrobatic feats, as he flitted now before, now beside, now above you, he hails you now, and asks that hospitality be extended to him.

Set forth a feast of suet on the window-sill, and he will need no bidding to come and partake of it. How daintily he helps himself to the tiniest morsels, never cramming his bill with gross mouthfuls as do his comrades at the board, the nuthatch and the downy woodpecker! They, like unbidden guests, doubtful of welcome or of sufferance even, make the most of time that may prove all too brief, and gorge themselves as greedily as hungry tramps; while he, unscared by your face at the window, tarries at his repast, pecking his crumbs with leisurely satisfaction. You half expect to see him swept from your sight like a thistledown by the gusty blast, but he holds bravely to his perch, unruffled in spirit if not in feathers, and defies his fierce assailant with his oft-repeated challenge.

As often as you spread the simple 285 
feast for him he will come and sit at your board, a confiding guest, well assured of welcome, and will repay you with an example of cheerful life in the midst of dreariness and desolation. In the still, bright days, his cheery voice rings through the frosty air, and when the thick veil of the snow falls in a wavering slant from the low sky its muffled cadence still heartens you.

What an intense spark of vitality must it be that warms such a mite in such an immensity of cold; that floats his little life in this deluge of frigid air, and keeps him in song while we are dumb with shivering! If our huge hulks were endowed with proportionate vitality, how easily we might solve the mysteries of the frozen north!

On some February day, when the first promise of spring is drifted to you in the soft south wind, the tenderness of spring is voiced in his love-note, brief but full of melody, and sweet as the evening song of the wood pewee. When the spring songsters come, he takes leave of you. $\mathrm{He}$ has seen you safely through the winter, and departs to the woods on affairs 286 


\section{THE CHICKADEE}

of his own. He is no longer a vagrant, but at home. in his own greenwood, yet as unfretted by the cares of housekeeping as he was by the heavy weariness of winter. 







\section{PLEASE DO NOT REMOVE CARDS OR SLIPS FROM THIS POCKET}

\section{UNIVERSITY OF TORONTO LIBRARY}

QH

81

R69

Robinson, Rowland Evans

In New England fields and woods

BioMed 


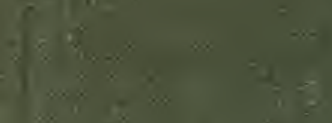

$x^{x}=-x$

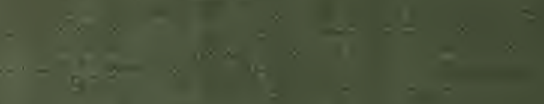
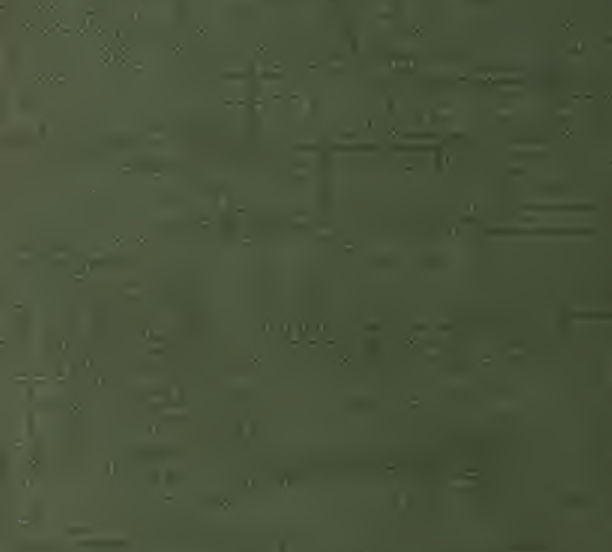

$6 x-3$

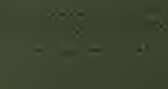

$-$ 